RENATA MARINO ROMANO

\title{
INFLUÊNCIA DO HORMÔNIO TIREOIDEANO NA ATIVIDADE DO GONADOTROFO
}

Tese apresentada ao Programa de PósGraduação em Fisiologia Humana do Instituto de Ciências Biomédicas da Universidade de São Paulo, para a obtenção do Título de Doutor em Ciências.

São Paulo

2011 


\section{INFLUÊNCIA DO HORMÔNIO TIREOIDEANO NA ATIVIDADE DO GONADOTROFO}

Tese apresentada ao Programa de PósGraduação em Fisiologia Humana do Instituto de Ciências Biomédicas da Universidade de São Paulo, para a obtenção do Título de Doutor em Ciências.

Área de Concentração: Fisiologia Humana Orientadora: Prof. ${ }^{a}$ Dr. ${ }^{a}$ Maria Tereza Nunes

Versão Original

São Paulo 2011 
DADOS DE CATALOGAÇÃO NA PUBLICAÇÃO (CIP)

Serviço de Biblioteca e Informação Biomédica do

Instituto de Ciências Biomédicas da Universidade de São Paulo

reprodução não autorizada pelo autor

\section{Romano, Renata Marino.}

Influência do hormônio tireoideano atividade do gonadotrofo / Renata Marino Romano. -- São Paulo, 2011.

Orientador: Maria Tereza Nunes.

Tese (Doutorado) - Universidade de São Paulo. Instituto de Ciências Biomédicas. Departamento de Fisiologia e Biofísica. Área de concentração: Fisiologia Humana. Linha de pesquisa: Bases moleculares da ação hormonal.

Versão do título para o inglês: Influence of thyroid hormone on gonadotrope activity.

Descritores: 1. Hormônios tireoidianos 2. Gonadotrofinas 3. Glândula pituitária 4. Hormônios sexuais I. Nunes, Maria Tereza II. Universidade de São Paulo. Instituto de Ciências Biomédicas.

Programa de Pós-Graduação em Fisiologia Humana III. Título. 
Candidato(a):

Título da Tese:
Renata Marino Romano.

Influência do hormônio tireoideano atividade do gonadotrofo.

Orientador(a):

Maria Tereza Nunes.

A Comissão Julgadora dos trabalhos de Defesa da Tese de Doutorado, em sessão pública realizada a I................................, considerou

\section{( ) Aprovado(a) \\ ( ) Reprovado(a)}

$\begin{array}{ll}\text { Examinador(a): } & \text { Assinatura: } \\ & \text { Nome: ....... } \\ & \text { Instituição: } \\ \text { Examinador(a): } & \text { Assinatura: } \\ & \text { Nome: ....... } \\ & \text { Instituição: } \\ \text { Examinador(a): } & \text { Assinatura: } \\ & \text { Nome: ........ } \\ & \text { Instituição: } \\ \text { Examinador(a): } & \text { Assinatura: } \\ & \text { Nome: ........ } \\ & \text { Instituição: } \\ & \text { Assinatura: } \\ \text { Presidente: } & \text { Nome: .............. } \\ & \text { Instituição: }\end{array}$




\section{Certificado}

Certificamos que o protocolo registrado sob $\mathrm{n}^{\circ} 029$ nas fls. 55do livro 02 para uso de animais em experimentação, sob a responsabilidade de Maria Tereza Nunes, Coordenador(a) da Linha de pesquisa "Influência do hormônio tireoideano na atividade do gonadotrofo" do qual participou(aram) 'o(s) alunos Renata Marino Romano está de acordo com os Princípios Éticos de Experimentação Animal adotado pelo Colégio Brasileiro de Experimentação Animal (COBEA) e foi aprovado pela COMISSÃO DE ÉTICA EM EXPERIMENTAÇÃO ANIMAL (CEEA) em 29.04.08, com validade de 3 anos.

São Paulo, 29 de abril de 2008.

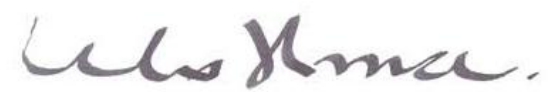

Prof. Dr. WOTHAN TAVARES DE LIMA Coordenador CEEA - ICB/USP

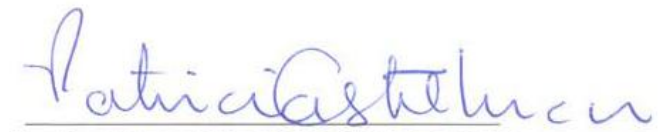

Profa. Dra. PATRICIA CASTELUCCI Secretária CEEA - ICB/USP 
REF.: Protocolo n ${ }^{\circ} 029 / 08$.

"Influência do hormônio tireoideano na atividade do gonadotrofo"

Prezada Professora,

Informo que a sua licença para uso de animais em experimentação, constante no protocolo em epígrafe, foi prorrogada até 29.04.2014.

Reitero que havendo alteração de metodologia e inserção de novos alunos ao projeto de pesquisa vinculado à referida licença a CEUA/ICB deverá ser informada.

\section{Cordialmente,}

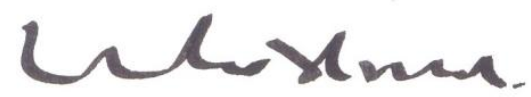

Prof. Dr. Wothan TAVARES DE Lima Coordenador da Comissão de Ética no Uso de Animal - ICB/USP

Ilma. Sra.

Profa Dra. MARia Tereza NunES

Departamento de Fisiologia e Biofisica

Instituto de Ciências Biomédicas - USP 


\section{DECLARACÄO}

Declaro para os devidos fins que RENATA MARINO ROMANO toi aprovado no Curso de Proteçăo Radiológica; promovido pelo Núcleo de Radioproteçăo do ICB/USP, no periodo de 14/D7 a 18/07/2008 com carga horária de 15 horas.

Säo Paulo, 11 de Agosto de 2008

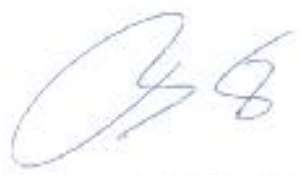

Prof. Dr. BENY SPIRA

NUCLEO DE PROTECARO RADIOLOGICA 
Ao Marco, à Patricia e ao Rodrigo

Aos meus pais, Fernando e Elvira, pelo apoio e compreensão 


\section{AGRADECIMENTOS}

À Prof. Dr. Maria Tereza Nunes, pela orientação e dedicação na minha formação.

Aos meus familiares, pelo amparo.

À Paula e à Érika, pela ajuda nos experimentos e pela amizade.

À Leonice, pelo auxílio técnico e amizade.

Aos colegas do laboratório de Biologia da Reprodução, pelo auxílio na imunohistoquímica das hipófises.

Aos colegas do Setor de Endocrinologia Experimental da Unifesp, pelo auxílio nos estudos dos testículos e epidídimos.

Ao Prof. Dr. Ricardo Iannace, pela correção gramatical desta Tese.

A todos os colegas do Laboratório de Fisiologia Endócrina, pela amizade e convívio.

E à Fapesp, pela viabilização financeira de meus estudos. 
"A mente que se abre a uma nova idéia jamais voltará ao seu tamanho original." Albert Einstein (1879-1955) 


\section{RESUMO}

ROMANO, R. M. Influência do hormônio tireoideano na atividade do gonadotrofo. 2011. 128 f. Tese (Doutorado em Fisiologia Humana) - Instituto de Ciências Biomédicas, Universidade de São Paulo, São Paulo, 2011.

Problemas no eixo hipotalâmico-hipofisário-gonadal são frequentes no hipo e no hipertireoidismo, embora pouco seja conhecido a respeito das bases moleculares destas alterações. Neste estudo foi avaliado o efeito da administração aguda e crônica na atividade do gonadotrofo em ratos Wistar tireoidectomizados aos 60 dias de idade e mantidos com tratamento de metimazol e $\mathrm{CaCl}_{2}$ por 21 dias. Após esse período os animais receberam $\mathrm{T} 3$ por injeção intravenosa nas doses correspondentes a $1 \mathrm{X}, 5 \mathrm{X}$ ou $50 \mathrm{X}$ à dose fisiológica $(0,3$ $\mu \mathrm{g} / 100 \mathrm{~g}$ PC) ou salina (TX) e foram decapitados após 30 minutos. O grupo crônico recebeu a dose correspondentes a $5 \mathrm{X}$ por 5 dias. Ratos falso-operados foram utilizados como controle. As hipófises foram removidas e submetidas às análises de expressão do mRNA do LH e do FSH por PCR em tempo real, adenilação da cauda poli(A) do LH pelo race PAT, e ainda expressão protéica do LH e do FSH por Western Blotting e imunohistoquímica. Os testículos foram avaliados quanto à expressão do receptor de LH e de andrógenos, por PCR em tempo real e Western Blotting. Os epidídimos forma avaliados quanto a expressão do receptor de andrógenos pela mesma metodologia. A concentração sérica de LH e FSH foi avaliada pelo sistema Luminex, o TSH, o T3 e a testosterona foram medidas por radioimunoensaio. Os resultados foram analisados estatisticamente pela ANOVA seguida do pós-teste de Tukey HSD para grupos com tamanhos amostrais diferentes, considerando-se diferença se $p<0,05$. A tireoidectomia elevou a concentração sérica de TSH e a administração aguda de T3 não alterou esse parâmetro. Já os animais tratados cronicamente com T3 apresentaram redução do TSH sérico. O hipotireoidismo ocasionou elevação no LH sérico, que foi reduzido após 3 horas do tratamento com T3. O hipertireoidismo acarretou diminuição do LH sérico. O mRNA do LH se elevou no hipotireoidismo e o tratamento com T3 reduziu a quantidade hipofisária. A cauda poli(A) do mRNA do LH foi reduzida no hipotireoidismo e não se alterou com os tratamentos. A proteína hipofisária foi reduzida no hipotireoidismo e se elevou com os tratamentos. Apesar do elevado LH sérico, a testosterona foi reduzida no hipotireoidismo e essa redução foi mantida nos tratamentos. O FSH sérico foi reduzido no hipotireoidismo e os tratamentos elevaram esse parâmetro ao observado no controle. $\mathrm{O}$ mRNA se elevou no TX e reduziu com o tratamento; a proteína estava reduzida no TX e se elevou nos tratamentos. O receptor de LH foi reduzido no TX e se elevou no tratamento, enquanto o receptor de andrógenos se comportou de forma inversa. O receptor de andrógenos 
do epidídimo foi aumentado no TX e reduzido pelos tratamentos. Esses resultados sugerem que o T3 age na modulação da função do gonadotrofo e na modulação da expressão dos receptores em tecidos-alvo.

Palavras-chave: Hormônios tireoidianos. Gonadotrofinas. Glândula pituitária. Hormônios sexuais. 


\begin{abstract}
ROMANO, R. M. Influence of thyroid hormone on gonadotrope activity. 2011. 128 p. Ph. D. thesis (Human Physiology) - Instituto de Ciências Biomédicas, Universidade de São Paulo, São Paulo, 2011.
\end{abstract}

Disturbances in the activity of the hypothalamus-pituitary-gonads axis are frequent in hypo and in hyperthyroidism, although little is known about the molecular basis of these alterations. In this study we evaluated the effect of acute administration of T3 on the activity of gonadotropes in male Wistar rats that were thyroidectomized at 60 days-old and kept under treatment with methimazole and $\mathrm{CaCl}$ for 20 days. After this period the animals received $\mathrm{T} 3$ by i.v. injection at doses corresponding to $1 \mathrm{X}, 5 \mathrm{X}$ or $50 \mathrm{X}$ the physiological dose $(0.3 \mu \mathrm{g} / 100 \mathrm{~g}$ BW) or saline (TX), and were decapitated 30 min thereafter. Hyperthryoid rats received T3 i.p. at doses of $5 \mathrm{X}$ for 5 days. Sham-operated animals were used as control. The pituitaries were removed and submitted to analyses of gene expression and adenylation status of poly(A) tail of LH and FSH mRNA by real-time PCR and RACE-PAT, respectively. LH and FSH expression was evaluated by Western blotting and immunohistochemistry (IHC). The testes were evaluated for the expression of $\mathrm{LH}$ receptor expression and androgen receptor expression by real-time PCR and Western Blotting. The epididymis were evaluated for the androgen receptor expression by the same methodology used for the testes. The serum concentration of FSH and LH were evaluated by Luminex kit (Millipore), whereas TSH, T3 and testosterone were measured by RIA. The results were statistically analyzed by ANOVA followed by Tukey HSD post hoc test for unequal sample sizes, considering statistical difference at $\mathrm{P}<0.05$. The thyroidectomy increased the TSH, $\mathrm{LH}$ and reduced the FSH and testosterone serum concentration. The acute T3 administration did not change the TSH and testosterone level, but increased the FSH and decreased the LH. After the T3 treatment for 5 days, the TSH and LH serum concentration was decreased and the testosterone was below the detectable limits. The FSH serum remained increased, equal the control level. After TX, another group of rats were treated with $1 \mathrm{X}, 5 \mathrm{X}$ or $50 \mathrm{X}$ the physiological dose for 1,2 or 3 hours before sacrifice. The LH serum concentration remains higher than TX and control group in 1 and 2 hours. The 3 hour group had a decrease in the serum level compared to TX. The FSH had an increase in the serum concentration in all times. The poly(A) tail of LH mRNA was reduced in TX and in the treatments. The protein content was reduced in TX and was elevated with treatments. The mRNA of FSH increased in TX and reduced after T3 treatment; the protein content was reduced in TX increased after treatment. The LH receptor was reduced in the treatment and reestablished in T3 treatment, while the opposite occurred 
with androgen receptor. In the epididymis the expression of androgen receptor was increased in TX and was reduced in the treatments with T3. These results suggest that T3 modulates the gonadotrope function and the gene expression of receptors in tissue-target.

Key-words: Thyroid hormones. Gonadotropins. Pituitary. Sexual hormones. 


\section{LISTA DE QUADROS}

Quadro 1.1 Primers sense e antisense utilizados para o ensaio de realtime PCR 36

Quadro 1.2 Primers sense e antisense utilizados para o ensaio de realtime PCR 47 


\section{LISTA DE FIGURAS}

Figura 1.1 Eficiência de diluição para o estudo do mRNA .......................................... 38

Figura 1.2 Curva de melt para os ensaios do ${ }_{\beta} \mathrm{LH},{ }_{\beta} \mathrm{FSH}$ e RPL19 ............................... 39

Figura 1.3 Método de RACE-PAT …............................................................................ 40

Figura 1.4 Eficiência de diluição para o estudo do mRNA para os genes de AR, LHR e RPL 19 em amostras de testículos

Figura 1.5 Curva de melt para os ensaios do AR, LHR e RPL 19 em amostras de testículos

Figura 1.6 Eficiência de diluição para o estudo do mRNA para o gene de AR em amostras de epidídimo

Figura 1.7 Curva de melt para os ensaios do AR em amostras de epidídimo

Figura 1.8 Eficiência de diluição para o estudo do mRNA para o gene de RPL 19 em amostras de epidídimo

Figura 1.9 Curva de melt para os ensaios do gene de RPL 19 em amostras de epidídimo

Figura 3.1 Delineamento experimental utilizado para o estudo do hipotireoidismo ....

Figura 3.2 Quantificações do mRNA, da proteína e da concentração sérica de ${ }_{\beta} \mathrm{FSH}$....... 68

Figura 3.3 Quantificações do mRNA, da proteína e da concentração sérica de LH ..........

Figura 3.4 O hipotireoidismo reduziu o conteúdo de mRNA do ${ }_{\beta} \mathrm{FSH}$ ligado ao ribossomo

Figura 3.5 O hipotireoidismo reduziu o conteúdo de mRNA do ${ }_{\beta} \mathrm{LH}$ ligado ao ribossomo

Figura 3.6 Análise do comprimento da cauda poli(A) do mRNA do ${ }_{\beta} \mathrm{LH}$ pelo método de RACE-PAT

Figura 3.7 Imunohistoquímica da hipófise para detecção de gonadotrofos marcados para ${ }_{\beta} \mathrm{LH}$

Figura 3.8 Imunohistoquímica da hipófise para detecção de gonadotrofos marcados para ${ }_{\beta} \mathrm{FSH}$

Figura 3.9 Imunohistoquímica da hipófise para confirmação da especificidade do anticorpo (controle negativo)

Figura 3.10 Peso da vesícula seminal drenada e não drenada (mg/100g PC) 75

Figura 3.11 Peso dos testículos, epidídimos e próstata ventral (mg/100 g PC)

Figura 3.12 Testosterona sérica 77

Figura 3.13 Corte histológico de testículo 78 
Figura 3.14 Expressão testicular de receptores de LH _.................................................. 79

Figura 4.1 Delineamento experimental para a avaliação do efeito do T3 após 30 min ..... 85

Figura 4.2 Delineamento experimental para a avaliação do efeito do T3 após 5 dias de tratamento

Figura 4.3 Delineamento experimental para a avaliação do efeito do T3 após 1, 2 e 3 horas do tratamento 86

Figura 4.4 Quantificações do mRNA, da proteína e da concentração sérica de ${ }_{\beta} L H$ 89

Figura 4.5 O tratamento com T3 elevou o conteúdo de mRNA do ${ }_{\beta} \mathrm{LH}$ ligado ao ribossomo

Figura 4.6 Análise do comprimento da cauda poli(A) do mRNA do ${ }_{\beta} \mathrm{LH}$ pelo método de RACE-PAT

Figura 4.7 Imunohistoquímica da hipófise para detecção de gonadotrofos marcados para ${ }_{\beta} \mathrm{LH}$

Figura 4.8 Concentração sérica de ${ }_{\beta} \mathrm{LH}$ após 1,2 e $3 \mathrm{~h}$ do tratamento 94

Figura 4.9 Quantificações do mRNA, da proteína e da concentração sérica de ${ }_{\beta} \mathrm{FSH}$ 96

Figura 4.10 O tratamento com T3 elevou o conteúdo de mRNA do ${ }_{\beta} F S H$ ligado ao ribossomo

Figura 4.11 Imunohistoquímica da hipófise para detecção de gonadotrofos marcados para ${ }_{\beta} \mathrm{FSH}$ 99

Figura 4.12 Concentração sérica de ${ }_{\beta} \mathrm{FSH}$ após 1, 2 e $3 \mathrm{~h}$ do tratamento 100

Figura 4.13 Peso da vesícula seminal drenada e não drenada 101

Figura 4.14 Peso testicular, epididimal e da próstata ventral 102

Figura 4.15 Testosterona sérica 103

Figura 4.16 Expressão testicular (A- mRNA e B-proteína) de receptores de andrógenos ... 104

Figura 4.17 Expressão testicular de receptor de LH ...................................................... 105

Figura 4.18 Expressão epididimal (mRNA) de receptores de andrógenos ......................... 107 


\section{LISTA DE TABELAS}

Tabela 2.1 Peso cardíaco, concentração sérica de TSH e de T3 total ............................... 63

Tabela 3.1 Peso e recuperação protéica hipofisária ...................................................... 70

Tabela 3.2 Morfometria linear dos túbulos seminíferos em ratos controle e TX ................ 78

Tabela 4.1 Peso e recuperação protéica hipofisária …....................................................... 88 


\section{SUMÁRIO}

Capítulo 1 - CONTEXTUALIZAÇÃ̃ E METODOLOGIA .......................................... 22

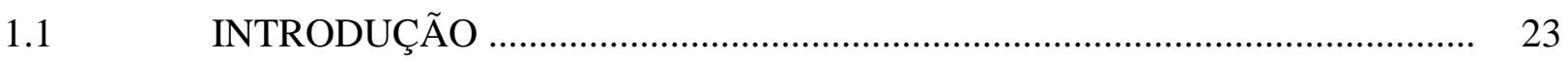

REVISÃO DE LITERATURA ….......................................................... 24

1.2.1 Hormônio tireoideano .............................................................................. 24

1.2.2 Função testicular e hormônios tireoideanos .................................................... 25

1.2.3 Eixo hipotalâmico-hipofisário-gonadal ...................................................... 26

1.2.4 Relevância clínica da alteração da função tireoideana sobre o eixo HHG ......... 28

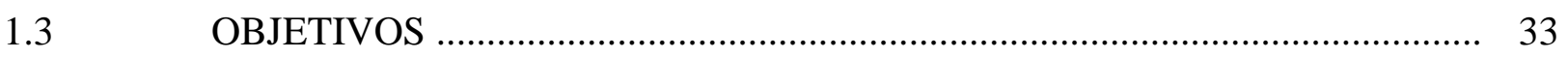

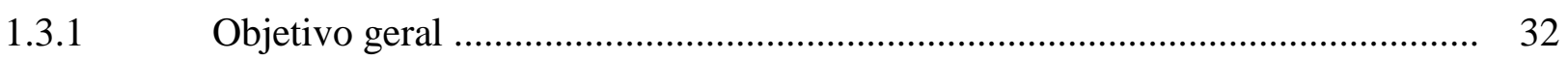

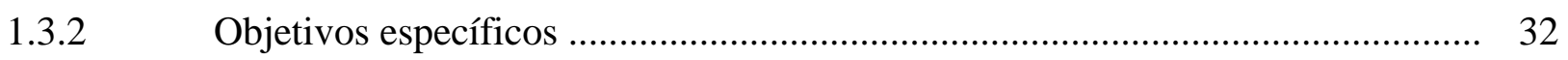

$1.4 \quad$ MATERIAL E MÉTODOS ................................................................ 33

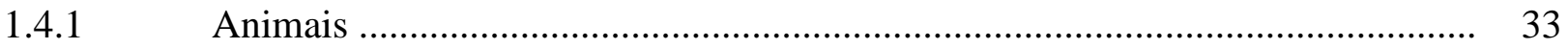

1.4.2 Delineamento experimental .................................................................. 33

1.4.3 Tecidos colhidos e parâmetros avaliados ................................................... 34

1.4.4 Análise da expressão do mRNA do ${ }_{\beta} \mathrm{LH}$ e do ${ }_{\beta} \mathrm{FSH}$...................................... 35

1.4.4.1 Elaboração dos primers específicos .............................................................. 35

1.4.4.2 Extração do RNA total .................................................................................. 36

1.4.4.3 PCR quantitativo em tempo real $(\mathrm{RTqPCR})$................................................ 37

1.4.4.3.1 Síntese do cDNA para o RTqPCR ................................................................. 37

1.4.4.3.2 Avaliação da expressão gênica do ${ }_{\beta} F \mathrm{FH}$ e do ${ }_{\beta} L \mathrm{H}$......................................... 37

1.4.5 Avaliação do grau de poliadenilação do mRNA do ${ }_{\beta} L H$ (RACE-PAT: Rapid Amplification of cDNA ends - Poly A Test) ............................................... 39

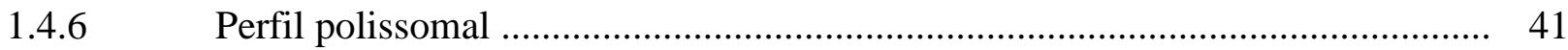

1.4.7 Expressão protéica do ${ }_{\beta} \mathrm{LH}$ e do ${ }_{\beta} \mathrm{FSH}$ (Western Blotting) .............................. 42

1.4.7.1 Extração da proteína total ............................................................................ 42

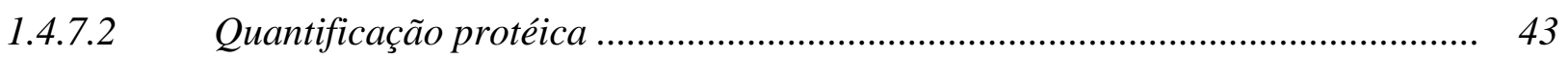

1.4.7.3 Preparo das alíquotas para aplicação no gel ................................................. 43

1.4.7.4 Preparo do gel de poliacrilamida e eletroforese das amostras ......................... 43

1.4.7.5 Transferência das amostras do gel para a membrana ....................................... 43

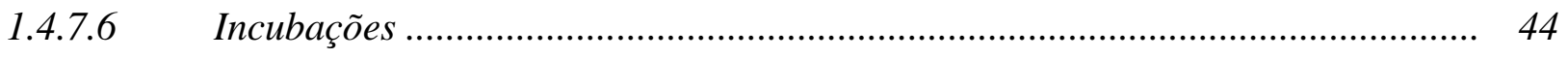

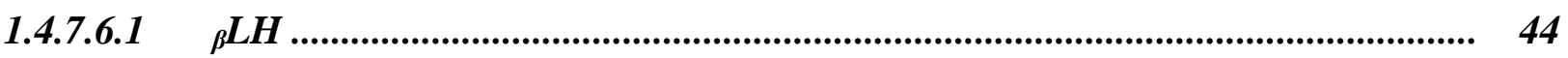


1.4.7.6.2 ${ }_{\beta} \mathrm{FSH}$

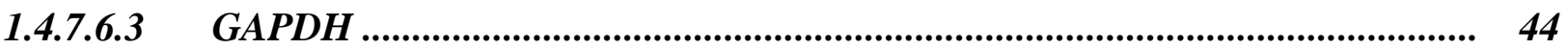

1.4.7.7 Deteç̧ão das bandas e quantificação …………………………………….... 45

1.4.8 Imunohistoquímica ............................................................................... 45

1.4.9 Análise da expressão do mRNA do receptor de andrógenos (AR) e receptor de LH (LHR) ...................................................................................... 46

1.4.9.1 Elaboração dos primers específicos ……………………………………….. 46

1.4.9.2 Extração do RNA total ............................................................................ 47

1.4.9.3 PCR quantitativo em tempo real (RTqPCR) .............................................. 47

1.4.9.3.1 Síntese do cDNA para o RTqPCR ................................................................... 47

1.4.9.3.2 Avaliação da expressão gênica do AR, LHR e RPL 19 nos testículos ............. 47

1.4.9.3.3 Avaliação da expressão gênica do AR e RPL 19 na cabeça, corpo e cauda do epidídimo ........................................................................................................ 51

1.4.10 Análise da expressão protéica do receptor de andrógenos (AR) e do receptor de LH (LHR) por Western Blotting ............................................................... 56

1.4.10.1 Extração de proteínas totais e quantificação protéica ………………………... 56

1.4.10.2 Preparo das alíquotas para aplicação no gel .................................................. 56

1.4.10.3 Preparo do gel de poliacrilamida e eletroforese das amostras ........................ 56

1.4.10.4 Transferência das amostras do gel para a membrana ...................................... 57

1.4.10.5 Incubações ......................................................................................... 57

1.4.10.5.1 Receptor de $\mathrm{LH}$...................................................................................... 57

1.4.10.5.2 Receptor de andrógenos ................................................................................ $\quad 57$

1.4.10.5.3 Alfa-actinina ........................................................................................... 58

1.4.10.6 Deteç̧ão das bandas e quantificação ……………………………………...... 58

1.4.11 Histologia dos túbulos seminíferos …………………………………..... 58

1.4.12 Dosagens séricas hormonais ………………………………………..... 59

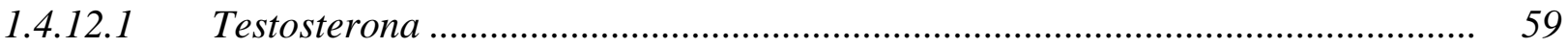

1.4.12.2 Triiodotironina (T3) ............................................................................. 59

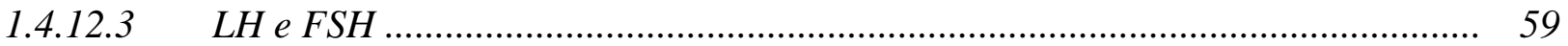

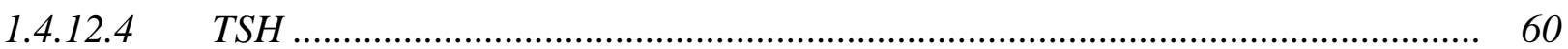

1.4.13 Análise estatística ................................................................................... '1

Capítulo 2 - EFETIVIDADE DO TRATAMENTO ……………………………………..... :

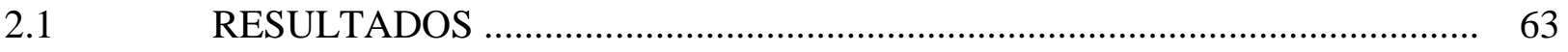

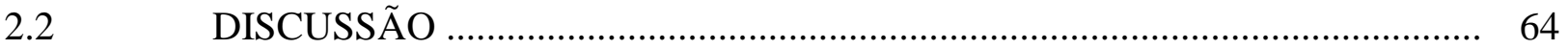


Capítulo 3 - EFEITOS DO HIPOTIREOIDISMO SOBRE O EIXO HIPOTALÂMICO-HIPOFISÁRIO-GONADAL

3.2.1.1 Expressão gênica e protéica e concentrações séricas de ${ }_{\beta} L H$ e ${ }_{\beta} F S H$................ 67

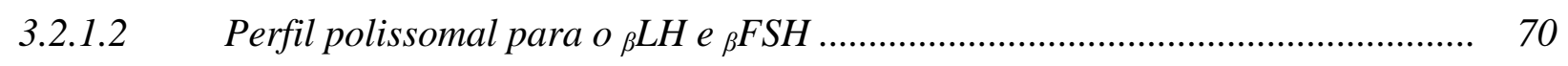

3.2.1.3 Análise da cauda do mRNA do ${ }_{\beta} L H$................................................................ 72

3.2.1.4 Imunohistoquímica do gonadotrofo .............................................................. 73

3.2.2 Repercussões nos órgãos reprodutivos ...................................................... 75

3.2.2.1 Peso dos testículos, epidídimos, vesícula seminal e próstata ventral ................ 75

3.2.2.2 Dosagem sérica de testosterona .................................................................... 77

3.2.2.3 Morfometria dos túbulos seminíferos ................................................................. 77

3.2.2.4 Expressão testicular de receptores de andrógenos e de LH .............................. 78

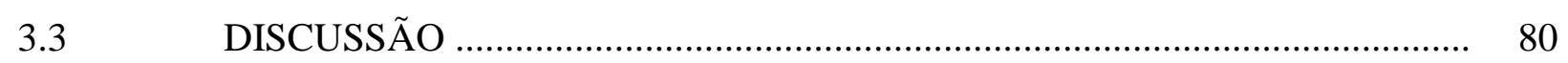

3.3.1 O hipotireoidismo altera mecanismos moleculares da síntese e secreção de

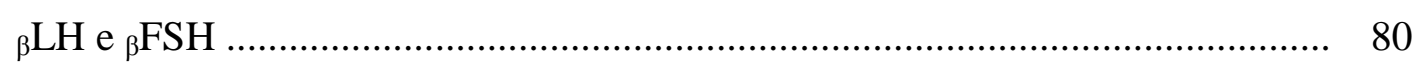

3.3.2 Testosterona sérica reduzida: relação com o elevado LH circulante e repercussões nos tecidos andrógeno-dependentes ........................................... 81

Capítulo 4 - RESPOSTA DO EIXO HIPOTALÂMICO-HIPOFISÁRIO-GONADAL AO TRATAMENTO COM TRIIODOTIRONINA (T3) ............................. 84

DELINEAMENTO EXPERIMENTAL _................................................ 85

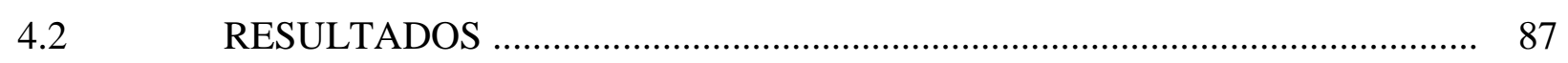

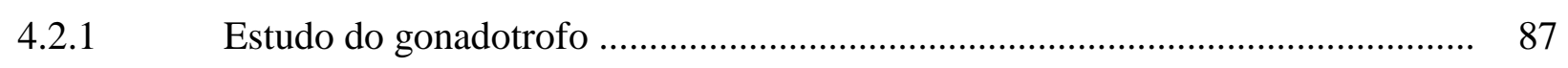

4.2.1.1 Peso hipofisário e recuperação protéica .......................................................... 87

4.2.1.2 Hormônio luteinizante: expressão, produção e secreção ................................... 88

4.2.1.2.1 Expressão gênica e protéica e concentrações séricas ........................................ 88

4.2.1.2.2 Perfil polissomal ....................................................................................... 90

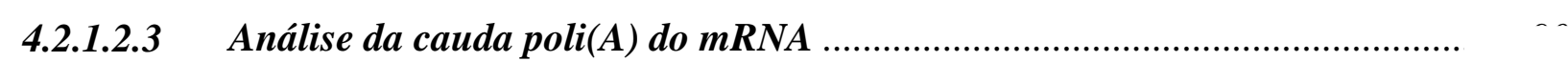

4.2.1.2.4 Morfologia do gonadotrofo por imunohistoquímica

4.2.1.2.5 LH sérico após 1, 2 e 3 horas do tratamento com T3 .................................... 94

4.2.1.3 Hormônio folículo estimulante: expressão, produção e secreção ...................... 95

4.2.1.3.1 Expressão gênica e protéica e concentrações séricas ....................................... 95

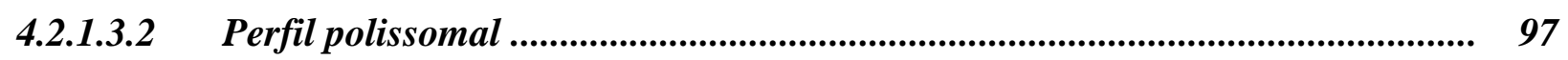


4.2.1.3.3 Morfologia do gonadotrofo por imunohistoquímica ...................................... 98

4.2.1.3.4 FSH sérico após 1, 2 e 3 horas do tratamento com T3 .................................... 100

4.2.2 Estudo dos tecidos periféricos ................................................................. 101

4.2.2.1 Peso dos testículos, epidídimos, vesícula seminal e próstata ventral ................. 101

4.2.2.2 Dosagem sérica de testosterona ....................................................................... 103

4.2.2.3 Expressão testicular de receptores de andrógenos e de $\mathrm{LH}$............................... 103

4.2.2.4 Expressão epididimal de receptores de andrógenos ......................................... 106

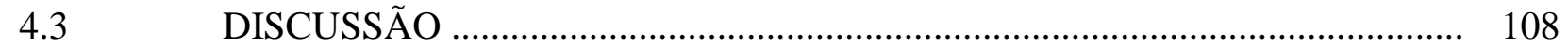

4.3.1 Modulação do ${ }_{\beta} \mathrm{LH}$ pelo hormônio tireoideano …........................................... 108

4.3.2 Modulação do ${ }_{\beta} \mathrm{FSH}$ pelo hormônio tireoideano ............................................ 110

4.3.3 Modulação do citoesqueleto de actina pelo hormônio tireoideano ..................... 110

4.3.4 Modulação da concentração sérica de testosterona e da expressão dos receptores de LH e de andrógenos pelo hormônio tireoideano ......................... 111

Capítulo 5 - CONCLUSÕES ............................................................................................... 114

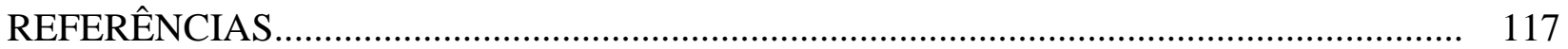


Capítulo 1

\section{CONTEXTUALIZAÇÃO E METODOLOGIA}




\subsection{INTRODUÇÃO}

O gonadotrofo é a célula adenohipofisária responsável pela produção dos hormônios LH (hormônio luteinizante) e FSH (hormônio folículo estimulante), ou gonadotrofinas, sintetizadas e liberadas a partir de estímulo do GnRH hipotalâmico (hormônio liberador de gonadotrofinas), o qual desempenha papel exponencial no controle da reprodução. Diversos fatores podem interferir no funcionamento do eixo hipotalâmico hipofisário gonadal, sendo que alterações de reprodução significativas são observadas em indivíduos que apresentam tanto o hiper quanto o hipotireoidismo.

Apesar de algumas alterações reprodutivas ocorrerem em função de patologias tireoideanas, não se conhece o papel do hormônio tireoideano (HT) sobre a função reprodutiva no indivíduo adulto. No entanto, durante o período pré-natal, infância e prépuberdade esse hormônio influencia uma série de mecanismos que são responsáveis pelo desenvolvimento em diversos aspectos, incluindo os relacionados à função reprodutiva. Nestes indivíduos, a expressão gonadal de receptores de HT é intensa, havendo diversos estudos que procuram elucidar os mecanismos envolvidos nesse processo. Contudo, o indivíduo adulto não apresenta quantidade expressiva de receptores de HT nas gônadas, atribuindo-lhe uma aparente insensibilidade ao hormônio.

Diferentemente do testículo, o gonadotrofo apresenta maior abundância de receptores de HT. Entretanto, como não há elemento responsivo ao hormônio tireoideano (TRE) nas suas unidades gênicas regulatórias, parece que este não participa diretamente da produção das gonadotrofinas.

O HT é capaz de desencadear efeitos que não dependem da sua interação clássica com receptores nucleares. Respostas funcionais são observadas em alguns tipos celulares, com eventual possibilidade da ativação da transcrição gênica, quando o hormônio se liga às integrinas de membrana, ou pela ativação de bomba $\mathrm{Na}^{+} / \mathrm{K}^{+}$ATPase, vias de fosforilação e polimerização de actina, por exemplo. Esses mecanismos são conhecidos como não genômicos e ocorrem, geralmente, num curto prazo de tempo.

Neste trabalho investigamos a possibilidade de o HT exercer algum tipo de modulação sobre o HHG, por meio do estudo da expressão dos genes do ${ }_{\beta} \mathrm{FSH}$ e ${ }_{\beta} \mathrm{LH}$, bem como por análises moleculares, como o real time PCR, Western Blotting, perfil polissomal, e morfológica pela imunohistoquímica; da expressão dos genes dos receptores de LH, de FSH e de andrógenos testiculares, também por real time PCR e Western Blotting; da expressão do 
gene do receptor de andrógenos nos epidídimos; e das concentrações séricas de LH, FSH, e testosterona.

\subsection{REVISÃO DE LITERATURA}

Nesta seção serão abordados alguns aspectos gerais da função testicular e de hormônios tireoideanos, eixo hipotalâmico hipofisário gonadal e relevância clínica da alteração tireoideana sobre o eixo $\mathrm{HHG}$, ressaltando a literatura específica do tema e a justificativa do desenvolvimento do presente projeto.

\subsubsection{Hormônio tireoideano}

Os HTs participam de etapas críticas da diferenciação, crescimento e metabolismo. São produzidos pela glândula tireóide, que se localiza logo abaixo da laringe e é formada por dois lobos lateralizados à traquéia e unidos por um istmo. É composta histologicamente de folículos preenchidos com colóide e revestidos por células epiteliais cúbicas, que secretam no interior desses folículos. O principal constituinte do colóide é a glicoproteína tiroglobulina, que serve de matriz para a síntese de HTs, sendo um reservatório destes. Para serem secretados, esses hormônios precisam retornar ao epitélio e atingir a corrente sanguínea (GUYTON e HALL, 2005; BIANCO e KIMURA, 2008).

A glândula tireóide produz e secreta HTs sob estímulo do TSH hipofisário (Tireotrofina), sob controle do feedback negativo exercido pelo T3 e pelo estímulo do TRH hipotalâmico. Em humanos, a tiroxina (T4) representa cerca de $93 \%$ da sua secreção hormonal, enquanto a triiodotironina (T3) representa os 7\% restantes O T3 apresenta maior bioatividade, sendo nos tecidos o T4 convertido em T3 por ação de desiodases (GUYTON e HALL, 2005; BIANCO e KIMURA, 2008).

O HT age nos tecidos alvo através da interação com TRs, que se apresentam dimerizados, especialmente com os receptores de ácido retinóico X (RXR) e acoplados ao seu elemento responsivo. No núcleo o hormônio interage com o receptor, desencadeando ou bloqueando a transcrição de diversos genes (YEN, 2001).

Mas a descoberta da interação do HT com outros sítios de ligação localizados na membrana celular e no citoplasma confere a esse hormônio a possibilidade de atuação em tecidos onde não se encontram receptores nucleares em abundância ou TRs (DAVIS et al., 2008a; 2008b; 2000). 


\subsubsection{Função testicular e hormônios tireoideanos}

A importância da atividade gonadal masculina sobre a reprodução humana teve maior ênfase a partir do desenvolvimento de biotecnologias como a fertilização in vitro (FIV) e a injeção intracitoplasmática de espermatozóides (ICSI). Para essas biotecnologias, além das condições de excelência de qualidade de ovócitos, é fundamental obter concentrações adequadas de espermatozóides viáveis, que serão maturados in vitro para se tornarem capazes de fertilização. Essa recente maior atenção ao gameta masculino aumentou a necessidade do conhecimento andrológico e, atualmente, já se considera que cerca da metade dos problemas conjugais de reprodução se deve à disfunção masculina (PATRIZIO; SANGUINETI; SAKKAS, 2008).

A espermatogênese é o processo que envolve a multiplicação e a maturação das células espermáticas, além da produção de gametas viáveis em concentrações adequadas, que serão transportados por um sistema reprodutivo necessariamente maduro e eficiente. $\mathrm{O}$ sistema reprodutivo compreende as gônadas masculinas (testículos), epidídimos e órgãos acessórios, como a próstata, as glândulas bulbouretrais e as vesículas seminais. O parênquima testicular compreende os túbulos seminíferos com o epitélio germinativo, onde se realiza a espermatogênese, além das células de Sertoli. Estas envolvem as células germinativas desde a periferia até o lúmen do túbulo, formando a barreira hemato-testicular. O tecido intersticial que ocupa cerca de 5\% do volume testicular total contém as células de Leydig, que são responsáveis pela produção testicular de andrógenos (KERR et al., 2006).

Os epidídimos são formados a partir da convergência dos túbulos seminíferos oriundos dos testículos. Sua principal função é promover um ambiente adequado para a maturação do espermatozóide, uma vez que sua capacidade de fertilização é extremamente baixa no ambiente testicular. Vários tipos celulares compõem os epidídimos, cuja estrutura se modifica ao longo de seu trajeto, até desembocar nos ductos deferentes. Entre as suas características secretórias, destacam-se a alta expressão e a atividade da enzima $5 \alpha$ redutase (que converte testosterona em dihidrotestosterona - DHT), endocitose de substâncias luminais (desprendidas durante a maturação dos espermatozóides), acidificação do meio luminal e reabsorção de água (ROBAIRE; HINTON; ORGEBIN-CRIST, 2006).

Nas glândulas acessórias são produzidos fluidos que comporão o ejaculado. A próstata destaca-se pela produção das proteínas antígeno prostático específico (PSA) e fosfatase ácida prostática (PAP). Ainda expressa grande quantidade de receptores androgênicos, sendo bastante sensível à redução das concentrações hormonais de testosterona e DHT. Nas 
vesículas seminais são produzidas e secretadas frutose, prostaglandinas e enzimas que diminuem a produção das espécies reativas de oxigênio, deletérias aos espermatozóides (RISBRIDGER e TAYLOR, 2006).

O impacto das alterações tireoideanas sobre a reprodução masculina foi assunto controverso durante muitos anos, apesar dos efeitos reconhecidos sobre outros órgãos e tecidos. Em parte, isso se deve ao fato de estudos antigos terem demonstrado que os testículos não eram metabolicamente responsivos ao hormônio tireoideano (HT) e também à baixa presença de receptores de hormônio tireoideano (TR) encontrados no órgão adulto (OPPENHEIMER et al., 1974; BARKER e KLITGAARD, 1952). Entretanto, nas duas últimas décadas, estudos conduzidos comprovaram que os HTs desempenham importante papel no desenvolvimento e na função testicular (WAGNER et al., 2008).

\subsubsection{Eixo hipotalâmico-hipofisário-gonadal}

A reprodução masculina e feminina é consequência de interações que vão desde o sistema nervoso central (hipotálamo) até as gônadas (testículos e ovários), passando pela hipófise. Este complexo mecanismo denominado de eixo hipotalâmico-hipofisário-gonadal sofre influência de diversos sistemas integrados.

A hipófise é formada por duas unidades morfofuncionais diferentes, a neurohipófise e a adenohipófise. A adenohipófise apresenta cinco tipos celulares principais: os somatotrofos, que representam 40 a 50\% do total das células e produzem hormônio do crescimento (GH); os lactotrofos, que representam $15 \%$ do total das células e produzem prolactina (PRL); os corticotrofos, que representam $15 \%$ das células e produzem a pro-opiomelanocortina, um precursor do hormônio adrenocorticotrófico (ACTH); os tireotrofos, que compreendem 5\% das células e produzem o hormônio tirotrófico (TSH); e, finalmente, os gonadotrofos, que compreendem $10 \%$ das células e produzem hormônio luteinizante (LH) e hormônio folículo estimulante (FSH) (NUNES, 2008).

As gonadotrofinas (LH e FSH) são sintetizadas e liberadas a partir de estímulo do GnRH hipotalâmico, o qual desempenha papel fundamental no controle da reprodução. O LH e o FSH atuam na gônada masculina e feminina para a produção de espermatozóides e maturação de ovócitos, em mecanismos onde os hormônios esteróides sexuais, como a testosterona, a progesterona e o estradiol, estão diretamente envolvidos. Essa relação do sistema nervoso central com os órgãos periféricos é estabelecida pelo eixo HHG (EVERETT, 2006). 
Diversos fatores podem interferir no funcionamento desse eixo; mais especificamente, observam-se alterações reprodutivas significativas em indivíduos que apresentam hiper ou hipotireoidismo (HATSUTA et al., 2004; KRASSAS, 2000; MEIKLE, 2004; TONI et al., 2005; VAN DEN BERGHE et al., 2002). Em geral, as alterações reprodutivas identificadas nessa última condição regridem após o tratamento com o HT (MEIKLE, 2004; TONI et al., 2005; WARTOFSKY et al., 2006), indicando que há algum tipo de relação entre o eixo HHG e o eixo hipotalâmico-hipofisário-tireoideano.

O LH e o FSH são glicoproteínas, assim como outro hormônio hipofisário, a tirotrofina TSH. O LH e o FSH são compostos por duas subunidades glicosiladas associadas por ligações não-covalentes, a $\alpha$ (comum) e a $\beta$ (específica), as quais são codificadas por genes distintos, localizados em diferentes cromossomos. As subunidades $\alpha,{ }_{\beta} \mathrm{LH}$ e ${ }_{\beta} \mathrm{FSH}$ estão expressas dentro das mesmas células (gonadotrofos bi-hormonais), embora algumas sejam capazes de secretar apenas um dos hormônios (gonadotrofos mono-hormonais). As etapas precursoras de clivagem e $\mathrm{N}$-glicosilação ocorrem no retículo endoplasmático, onde a tradução dos mRNAs específicos gera os heterodímeros imaturos $\alpha / \beta$. Ao longo do complexo de Golgi ocorre a progressiva aquisição da forma madura do hormônio, por glicosilações, dobramentos específicos e interação dos heterodímeros, que são alcançados no interior dos grânulos de secreção (BOUSFIELD et al., 2006; COUNIS et al., 2005).

As células que secretam FSH são grandes e apresentam grânulos de aproximadamente $200 \mu \mathrm{m}$, retículo endoplasmático rugoso e complexo de Golgi extensos, sendo que nestas estruturas se dá o processo de glicosilação do hormônio. As células que secretam LH apresentam grânulos secretórios menores que se acumulam em um pólo celular, próximo à periferia, e com o complexo de Golgi menos desenvolvido que nas células que secretam FSH. O FSH possui peso molecular de 34 kDa e consiste em 210 resíduos de aminoácidos, ao passo que o LH é uma proteína de peso molecular 28,5 kDa, com 204 resíduos de aminoácidos. A meia-vida plasmática do FSH humano é de aproximadamente 240 minutos e a do LH, 30 minutos (NORMAN e LITWACK, 1997).

A interação do GnRH com os receptores de membrana do gonadotrofo ativa vias de sinalização que geram cFos e cJun, fatores de transcrição que se dimerizam, atuando em genes que apresentam sítio de reconhecimento AP-1. Também ocorre a ativação de Egr-1 (proteína inicial de resposta ao crescimento 1) através da sinalização via PKC e MAPK. Essas vias de sinalização são melhor definidas para a síntese de $\mathrm{LH}$, tendo em vista que os mecanismos envolvidos com a síntese de FSH ainda são pouco conhecidos (COUNIS et al., 2005). 
Além de LH, o gonadotrofo hipofisário produz uma pequena quantidade endógena de GnRH, que auxilia na exocitose dos grânulos de LH pela abertura dos canais de cálcio, contribuindo para os níveis basais de secreção desse hormônio (KRSMANOVIC et al., 2000).

A relação entre HT e eixo gonadal também pode ser evidenciada em estudos desenvolvidos por Lovejoy et al. (1997), que demonstraram que, após três horas do tratamento com T3, ocorre elevação em $42 \%$ da concentração sérica de testosterona e 150\% da globulina transportadora.

Ainda, há evidências de que o número de células germinativas testiculares diminui no hipotireoidismo; em contrapartida, observa-se a sua elevação durante o hipotireoidismo transitório, apesar da quantidade de espermatozóides vivos estar diminuída em ambas as situações. Nesse mesmo estudo, verifica-se a redução da atividade de enzimas testiculares, como a superoxido dismutase, catalase e glutationa peroxidase, sugerindo que o hormônio tireoideano exerça regulação direta sobre a fisiologia e sistema de defesa antioxidante do testículo (SAHOO et al., 2008).

A enzima desiodase do tipo 2 é expressa nos testículos de ratos adultos, mais precisamente nas espermátides alongadas, e sua atividade é induzida pelo hipotireoidismo, sugerindo que o HT possa ter efeito direto na espermatogênese de ratos adultos (WAJNER et al., 2007). A morfologia espermática é alterada no sêmen de indivíduos hipotireóideos, sendo restabelecida após tratamento com o HT (KRASSAS et al., 2008). Ainda assim, é detectada a presença de TRs no epidídimo, principalmente no compartimento citoplasmático, cuja quantidade se eleva em significativa escala no hipotireoidismo (mRNA e proteína) (PAUL et al., 2008).

1.2.4 Relevância clínica da alteração da função tireoideana sobre o eixo hipotalâmicohipofisário-gonadal

Os hormônios tireoideanos desempenham papel conhecido sobre a reprodução, desde a fase de desenvolvimento inicial da gônada. Durante a fase pré-púbere, os testículos são altamente influenciados pelos níveis de HTs, os quais respondem pelo crescimento e pela maturação das células testiculares. Nesse período, o hipotireoidismo leva ao hipergonadismo e à imaturidade celular, ao passo que o hipertireoidismo acarreta hipogonadismo e maturidade celular precoce em ratos (ARIYARATANE et al., 2000; CHAPIN et al., 1996), sendo que os TRs estão presentes nos testículos de ratos desde o período perinatal até a vida adulta (BUZZARD et al., 2000, JANNINI et al., 2000). Durante esse mesmo período também são 
encontradas desiodases nesses tecidos: enzimas que modulam a conversão do T4 a T3, e consequentemente a ação dos HT (WAGNER et al., 2003, WAJNER et al.,2007).

Em meninos com hipotireoidismo, os níveis séricos de PRL (prolactina) e TSH são elevados em função do exagerado estímulo do TRH. Embora as concentrações séricas basais de LH, FSH, estrona e estradiol sejam elevadas, a resposta das gonadotrofinas ao GnRH está atenuada. Como resultado da elevação no FSH ocorre o aumento gonadal, mas a elevada PRL inibe o efeito do LH sobre a célula de Leydig, prejudicando a produção de testosterona. Meninos com hipotireoidismo primário apresentam elevação de TSH, mas somente aqueles com hipergonadismo têm a PRL e gonadotrofinas exageradamente elevadas. Alterações estas revertidas pela terapia de reposição com hormônio tireoideano (MEIKLE, 2004).

A hiperprolactinemia pode se desenvolver em pacientes com hipotireoidismo primário por alguns mecanismos conhecidos: (a) em resposta ao estado hipotireoideo há uma descarga compensatória central hipotalâmica de TRH, resultando na estimulação da produção de PRL; (b) a eliminação da PRL da circulação sistêmica está reduzida, o que contribui ao aumento das suas concentrações; e (c) há diminuição da sensibilidade do lactotrofo ao efeito supressor da dopamina (HEKINSON et al., 2010). Em homens a hiperprolactinemia está mais frequentemente relacionada à presença de macroadenomas hipofisários (DE ROSA et al., 2003).

Entretanto, em homens com hipotireoidismo primário, raramente se observa a hiperprolactinemia (exceto nos casos em que há tumores hipofisários relatados), contrariamente ao que ocorre na mulher. A maioria dos estudos em homens com hipotireoidismo primário e hipogonadismo atesta níveis normais de LH e FSH. Porém, a administração de GnRH a esses pacientes não resulta em liberação de gonadotrofinas hipofisárias, denotando incapacidade do gonadotrofo em responder a esse estímulo (MEIKLE, 2004).

Não há relatos de que a região promotora dos genes que codificam a subunidade $\beta$ específica do LH ou FSH ou ainda do GnRH apresentem TRE (MEIKLE, 2004; TONI et al., 2005). Além disso, a densidade de receptores de HT (TR) é baixa nas regiões hipotalâmicas em que os neurônios do GnRH se encontram (TONI et al., 2005), dados que sugerem que as ações dos HT sobre a hipófise e o hipotálamo ocorreriam predominantemente por modulação da estabilidade ou do processamento pós-transcricional do mRNA das gonadotrofinas ou do GnRH, levando a alterações da sua bioatividade (MEIKLE, 2004), ou ainda por inputs neuroendócrinos em outras regiões do sistema nervoso central, sensíveis ao hormônio tireoideano, que regulariam a síntese e/ou secreção de GnRH (TONI et al., 2005). Entretanto, 
a expressão de TRs em gonadotrofos é bastante representativa, maior até do que em tireotrofos e somatotrofos, o que indica a possibilidade de regulação da função dos gonadotrofos por esse hormônio, por mecanismo ainda desconhecido, já que, como foi comentado, não há TRE na região promotora dos genes que codificam o FSH e LH (ALKEMADE et al., 2006; FLIERS et al., 2006).

Sabe-se que o mRNA do ${ }_{\beta} \mathrm{LH}$ se altera em resposta aos níveis de HT, e que os TRs se expressam numa variedade de outros tipos celulares da hipófise anterior, incluindo lactotrofos e somatotrofos (TONI et al., 2005). Dessa forma, é possível, ainda, que o HT atue de maneira indireta sobre os gonadotrofos, interferindo com a secreção de mediadores a partir das células vizinhas, como o peptídeo vasointestinal (VIP), cuja imunorreatividade se encontra bastante aumentada na hipófise de ratos adultos hipotireoideos. A distribuição das células VIP em torno de células de LH sugere que possa existir uma interação parácrina/justácrina entre elas (TONI et al., 2005).

Tanto em ratos castrados quanto em hipotireóideos observa-se a redução nos níveis de TRH e peptídeos derivados do prepro-TRH em regiões do sistema límbico, o que tem sido relacionado às alterações comportamentais identificadas no hipogonadismo e hipotireoidismo (PEKARY e SATTIN, 2001). Vale ressaltar que, ao contrário do que ocorre em áreas do sistema límbico, a produção de TRH em neurônios que se dirigem à eminência média hipotalâmica e que participam, portanto, do controle da secreção de TSH, encontra-se aumentada no hipotireoidismo. Embora estudos similares ainda não tenham sido desenvolvidos avaliando o papel da testosterona nos neurônios parvocelulares do núcleo paraventricular, sede dos neurônios TRHérgicos que controlam a atividade tireoideana, essa possibilidade não pode ser descartada.

Observou-se que o HT está relacionado à ativação pós-transcricional das convertases 1/3 (PC1/3), primariamente, e secundariamente da 2 (PC2), as quais atuam na conversão do pró-TRH a TRH, de modo que, com a aumento da atividade dessas enzimas em indivíduos hipotireoideos, eleva-se a produção de TRH (PERELLO et al., 2006). Essas convertases parecem atuar no processamento de outros pró-hormônios, já que: (a) camundongos knockout para PC1/3 e PC2 são pequenos devido ao processamento alterado do proGHRH; (b) camundongos knockout para PC2 apresentam distúrbios no processamento do pró-glucagon e (c) pacientes que não expressam $\mathrm{PC} 1 / 3$ apresentam vários distúrbios, entre os quais a infertilidade, o que levanta a possibilidade de que o processamento de pró-GnRH possa estar comprometido no hipotireoidismo, visto que o HT, via convertases, poderia participar desse processamento pós-transcricional. 
Ações não genômicas dos hormônios tireoideanos têm sido descritas em várias células, como alterações no transporte de cálcio, sódio e glicose através da membrana plasmática e promoção da atividade de proteínas-quinases (DAREZZO et al., 2004; DAVIS et al., 2000).

Sobre astrócitos e somatotrofos, o HT atua na organização dos filamentos de F-actina, promovendo a organização do citoesqueleto. Na ausência desse hormônio, os neurônios também são incapazes de promover sinapses adequadas (SIEGRIST-KAISER et al., 1990) e os somatotrofos apresentam comprometimento da síntese e secreção de GH (GOULARTSILVA et al., 2006), por desarranjos no citoesqueleto, bem como em consequência à redução na transcrição desse gene (ação genômica).

Alterações no citoesqueleto de actina não se restringem aos somatotrofos. Observa-se que no hipotireoidismo há um desarranjo generalizado do citoesqueleto de toda a hipófise, indicando a possibilidade de os gonadotrofos serem igualmente afetados. Deste modo, é grande a possibilidade de que nessa situação haja também comprometimento da síntese e liberação dos hormônios gonadotróficos, já que para a síntese protéica há necessidade de direcionamento do mRNA ao ribossomo, bem como de fatores de alongamento que se encontrem ligados ao citoesqueleto de actina, e que, para a secreção hormonal, se faz necessária a mobilização de vesículas em direção à membrana plasmática, processos que dependem de um citoesqueleto organizado.

Com base nas evidências expostas relacionadas às funções tireoideana e gonadal, e reconhecendo a necessidade de abordagem mais detalhada desse tema ainda pouco explorado e bastante controvertido, propomos com este projeto investigar o papel do hormônio tireoideano, na regulação da expressão dos genes do ${ }_{\beta} \mathrm{FSH}$ e ${ }_{\beta} \mathrm{LH}$, por meio de análises moleculares, como real-time PCR e Western Blotting, perfil polissomal, e celulares, como a imunohistoquímica; da expressão dos genes dos receptores de LH, de FSH e de andrógenos testiculares, também por real time PCR e Western Blotting; da expressão do gene do receptor de andrógenos nos epidídimos; e das concentrações séricas de LH, FSH e testosterona. 


\subsection{OBJETIVOS}

\subsubsection{Objetivo geral}

Avaliar a influência do hormônio tireoideano sobre o eixo hipotalâmico-hipofisáriogonadal, através do estudo morfológico e funcional do gonadotrofo, da expressão gênica dos receptores testiculares de $\mathrm{LH}$, e da expressão de receptores de andrógenos testiculares e epididimais.

\subsubsection{Objetivos específicos}

- Avaliar o efeito do hormônio tireoideano em condições de eu, hipo, hipertireoidismo e após administração aguda de $\mathrm{T}_{3}$ :

○ na expressão gênica das gonadotrofinas hipofisárias, por meio da determinação do conteúdo hipofisário do mRNA do ${ }_{\beta} \mathrm{FSH}$ e ${ }_{\beta} \mathrm{LH}$; das proteínas ${ }_{\beta} \mathrm{FSH} \mathrm{e}_{\beta} \mathrm{LH}$, bem como da taxa de tradução destes transcritos, por meio do perfil polissomal;

○ nas concentrações séricas de FSH, LH, testosterona, TSH e T3;

○ em aspectos morfológicos dos gonadotrofos e do citoesqueleto de actina;

○ na expressão gênica do receptor testicular de LH;

○ na expressão gênica dos receptores testiculares e epididimais de andrógenos, pela análise do conteúdo do mRNA e da proteína. 


\subsection{MATERIAL E MÉTODOS}

O capítulo trata da descrição detalhada das metodologias utilizadas para o estudo dos diferentes aspectos deste trabalho. O PCR em tempo real foi utilizado para a análise da expressão gênica das gonadotrofinas hipofisárias $\left({ }_{\beta} \mathrm{FSH} \mathrm{e}_{\beta} \mathrm{LH}\right)$; dos receptores testiculares de LH e de andrógenos; do receptor de andrógenos nos segmentos do epidídimo. O Western Blotting foi utilizado para a avaliação do conteúdo protéico desses mesmos genes. O perfil polissomal foi utilizado para verificar a taxa de tradução dos transcritos das gonadotrofinas. A imunohistoquímica foi utilizada no estudo morfológico dos gonadotrofos e do citoesqueleto de actina. E diferentes metodologias foram utilizadas para a determinação das concentrações séricas de FSH, LH, testosterona, TSH e T3.

\subsubsection{Animais}

Foram utilizados ratos Wistar adultos eutireoideos, que sofreram cirurgia fictícia para remoção da tireóide, ou tireoidectomizados cirurgicamente. Os animais tireoidectomizados receberam uma solução de metimazol $0,03 \%$ e $\mathrm{CaCl}_{2}$,, $5 \%$ na água de beber por vinte e um dias, e os eutireoideos, somente água. Eles foram mantidos nas instalações do biotério do Departamento de Fisiologia e Biofísica do ICB, em sala com temperatura controlada de $23 \pm 1$ ${ }^{\circ} \mathrm{C}$, ciclo claro/escuro: $12 \mathrm{~h} / 12 \mathrm{~h}$, e ração comercial balanceada ad libitum. Cumpre ressaltar que todos os procedimentos estão em conformidade com os princípios éticos na experimentação animal e foram aprovados pelo Comitê de Bioética em Experimentação Animal do Instituto de Ciências Biomédicas - ICB/USP (protocolo 029/55/02).

\subsubsection{Delineamento experimental}

O delineamento experimental utilizado foi o de blocos completos ao acaso (fator para formação de blocos: tratamento e horário), sendo os animais divididos nos seguintes grupos:

1. CONTROLE - animais eutireoideos (sofreram cirurgia fictícia) que receberam solução salina iv (intravenosa), 30 minutos antes da eutanásia;

2. TX - animais tireoidectomizados (TX) que receberam solução salina iv, 30 minutos antes da eutanásia; 
3. TXT3 $_{0,3}$ - animais TX que receberam dose de $T_{3}$ equivalente à dose fisiológica (DILLMANN et al., 1983; 0,3 $\mu \mathrm{g} / 100 \mathrm{~g}$ PC, iv), 30 minutos antes da eutanásia;

4. TXT3 $_{1,5}$ - animais $\mathrm{Tx}$ que receberam dose de $\mathrm{T}_{3}$ equivalente à $5 \mathrm{X}$ a dose fisiológica $(1,5 \mu \mathrm{g} / 100 \mathrm{~g}$ PC, iv), 30 minutos antes da eutanásia;

5. TXT3 $_{15}$ - animais Tx que receberam dose de $\mathrm{T}_{3}$ equivalente à $50 \mathrm{X}$ a dose fisiológica (15 $\mu \mathrm{g} / 100 \mathrm{~g}$ PC, iv), 30 minutos antes da eutanásia;

6. TXT3 $_{\text {crônico }}$ - animais Tx que receberam doses de $\mathrm{T}_{3}(1,5 \mu \mathrm{g} / 100 \mathrm{~g} \mathrm{PC}$, ip) por cinco dias antes da eutanásia;

Os animais foram anestesiados com uma solução de quetamina (10 mg/100 g PC) e xilazina ( $2 \mathrm{mg} / 100 \mathrm{~g}$ PC), para serem submetidos aos procedimentos cirúrgicos, e antes da injeção intravenosa de $\mathrm{T}_{3}$ ou salina.

O hormônio utilizado no tratamento experimental foi a triiodotironina (SIGMAALDRICH, Inc., Saint Louis, MO, USA), dissolvida em $\mathrm{NaOH} 2 \mathrm{M}$ e depois diluída em salina, para as concentrações descritas no planejamento experimental, logo antes do uso.

\subsubsection{Tecidos colhidos e parâmetros avaliados}

Após o período do tratamento, os animais foram decapitados e o sangue colhido em tubo de ensaio. Seguiu-se a sua centrifugação a 2.500 g por 5 minutos, a separação do soro em alíquotas individuais e congelação a $-20{ }^{\circ} \mathrm{C}$ para as posteriores análises hormonais.

As hipófises inteiras (adeno e neuro) foram imediatamente removidas, acondicionadas em tubo tipo eppendorf autoclavado, congeladas em nitrogênio líquido e mantidas a $-70{ }^{\circ} \mathrm{C}$ para as extrações de RNA ou proteína. Para o experimento de imunohistoquímica, as hipófises foram fixadas em paraformaldeído 2\%, emblocadas em Tissue Freezing Medium (Triangle Biomedical Sciences, Durham, NC, USA) e rapidamente congeladas em 2-metilbutano a -80 ${ }^{\circ} \mathrm{C}$.

Os testículos, epidídimos, vesícula seminal e próstata ventral foram colhidos e pesados; a seguir, esses dados foram convertidos a pesos relativos $(\mathrm{mg} / 100 \mathrm{~g}$ de peso corporal) e analisados. Colheram-se também amostras de testículos para estudo histológico. Amostras de testículos e epidídimos também foram retiradas, congeladas em nitrogênio líquido e mantidas a $-70 .{ }^{\circ} \mathrm{C}$ para estudos de mRNA e proteína. 
O coração foi retirado, pesado e mantido em estufa a $36{ }^{\circ} \mathrm{C}$, por 24 horas para desidratação e nova pesagem. Os valores foram transformados na proporção em mg para cada $100 \mathrm{~g}$ de peso corporal $(\mathrm{mg} / 100 \mathrm{~g} \mathrm{PC})$.

\subsubsection{Análise da expressão do mRNA do ${ }_{\beta} \mathrm{LH}$ e do ${ }_{\beta} \mathrm{FSH}$}

A metodologia para a análise da expressão do mRNA do LH e do FSH envolveu a construção dos primers específicos, extração do RNA total e PCR em tempo real (RTqPCR). O detalhamento dessas metodologias está apresentado nos subitens a seguir.

\subsubsection{Elaboração dos primers específicos}

As sequências do mRNA do ${ }_{\beta} \mathrm{FSH}$ e do ${ }_{\beta} \mathrm{LH}$ foram obtidas no banco de dados do National Center for Biotechnology Information - NCBI (http://www.ncbi.nih.nlm.gov), e o registro dessas sequências utilizadas no presente estudo é o seguinte:

- NM_012858 Rattus norvegicus ${ }_{\beta} \mathrm{LH}$ variante 1, com 533 pb (última atualização em 16/03/2008);

- NM_001007597 Rattus norvegicus ${ }_{\beta} \mathrm{FSH}$, com 393 pb (última atualização em 20/04/2008).

Essas sequências foram submetidas aos seguintes procedimentos: a) construção de primers sense e antisense através da utilização do programa Primer (http://www.ncbi.nih.nlm.gov); b) análise da especificidade das sequências sense e antisense obtidas aos mRNAs de estudo pela comparação com outras sequências do banco de dados do NCBI através do programa BLAST (http://www.ncbi.nih.nlm.gov); e c) análise da estabilidade desses primers pelo programa OligoAnalyzer (34L34P://www.idtdna.com/analyzer/ applications/oligoanalyzer). Atendidas todas as exigências, as seguintes sequências de $20 \mathrm{pb}$ (pares de bases) foram elaboradas pela Invitrogen Life Technologies (Camarillo, CA, USA), conforme se observa no Quadro 1.1. 
Quadro 1.1 - Primers sense e antisense utilizados para o ensaio de realtime PCR dos genes ${ }_{\beta} \mathrm{FSH},{ }_{\beta} \mathrm{LH}$ e RPL19 (constitutivo)

\begin{tabular}{|cc|}
\hline Primers & Sequência \\
\hline Sense: beta FSH & 5'-AAGTCGATCCAGCTTTGCAT-3' \\
Antisense: beta FSH & 5'-GTCCCAGGCCTCTTACAGTG-3' \\
Sense: beta LH & 5'-ATGAGTTCTGCCCAGTCTGC-3', \\
Antisense: beta LH & 5'-GTGGGTGGGCATCAGAAGAG-3' \\
Sense: RPL19 & 5'-AGTATGCTTAGGCTACAGAA-3' \\
Antisense: RPL19 & 5'-TCCCTTAGACCTGCTTGGTC-3',
\end{tabular}

\subsubsection{Extração do RNA total}

A hipófise retirada do animal foi imediatamente depositada num tubo tipo eppendorff de 2,0 mL, congelada em nitrogênio líquido e armazenada no freezer a $-70{ }^{\circ} \mathrm{C}$ para a posterior extração. A extração do RNA total foi baseada na metodologia da guanidina-fenolclorofórmio e precipitação com isopropanol (CHOMCZYNSKI et al., 1987).

Esse método é dividido em três etapas, as quais consistem na homogeneização em solução D (4 M tiocianato de guanidina; $25 \mathrm{Mm}$ citrato de sódio, $\mathrm{pH}$ 7,0; 0,5 \% lauril sarcosinato de sódio e 0,1 M 2-mercaptoetanol), extração em fenol saturado em água e clorofórmio, precipitação em isopropanol e lavagem em etanol 75\%. Ao final desse processo obteve-se um extrato de RNA total, que foi dessecado em SpeedVack, com temperatura e vácuo controlados, mantendo a integridade do RNA extraído.

$\mathrm{O}$ pellet resultante da secagem foi ressuspendido em $40 \mu \mathrm{L}$ de água DEPC $0,01 \%$ inativada por autoclavagem, colocado em banho-maria a $65{ }^{\circ} \mathrm{C}$ por 15 minutos e mantido em gelo por 5 minutos. Diluiu-se uma alíquota em outro eppendorff na proporção de 1:18 e fez-se a leitura em espectrofotômetro. Foi utilizada a absorbância de $260 \mathrm{~nm}$ para o cálculo de concentração do RNA, tendo como referência o valor de $40 \mu \mathrm{g} / \mathrm{mL}$ para cada unidade de densitometria óptica. As amostras também foram lidas em $280 \mathrm{~nm}$, comprimento de onda em que proteínas e afins também podem ser mensuradas. Apenas as amostras que apresentaram a razão 260/280 > 1,7 foram utilizadas no estudo. A concentração foi expressa em $\mu \mathrm{g} / \mu \mathrm{L}$. O RNA total extraído ressuspendido foi conservado em freezer a $-70{ }^{\circ} \mathrm{C}$. 
A integridade do RNA foi confirmada pela visualização das bandas do RNA ribossomal $28 \mathrm{~S}$ e $18 \mathrm{~S}$, no transiluminador, após eletroforese em gel de agarose a $1 \%$, e corado com brometo de etídio.

\subsubsection{PCR quantitativo em tempo real (RTqPCR)}

A expressão do mRNA do ${ }_{\beta} \mathrm{FSH}$ e do ${ }_{\beta} \mathrm{LH}$ foi avaliada pelo método do PCR quantitativo em tempo real (RTqPCR). Esse método utiliza corantes fluorescentes que combinam as etapas de amplificação e detecção da reação de PCR. O aumento do sinal fluorescente é proporcional à quantidade de DNA produzida durante cada ciclo do PCR. Reações individuais são caracterizadas por um ciclo de PCR no qual o primeiro pico de fluorescência ultrapassa um limite definido, parâmetro conhecido como threshold cycle $\left(C_{t}\right)$, que será utilizado para quantificar a reação (NOLAN et al., 2006).

\subsection{Síntese do cDNA para o RTqPCR}

A partir de $1 \mu \mathrm{g}$ do RNA total, foi realizado o ensaio de reação de transcrição reversa (RT) com oligo(dT) para a síntese de uma fita de DNA complementar ao mRNA (ssDNA). Para isto, adicionou-se em cada amostra $1 \mu \mathrm{L}$ de oligo(dT) $(0,5 \mu \mathrm{g} / \mu \mathrm{L}$; Invitrogen, Corp., Camarillo, CA, USA) e incubou-se a $65^{\circ} \mathrm{C}$ por $10 \mathrm{~min}$, para abertura da fita de RNA. Em seguida acrescentou-se a seguinte mistura: $1 \mu \mathrm{L}$ de RNAse Out (inibidor de RNAse $-25 \mathrm{U}$ ), 4 $\mu \mathrm{L}$ tampão da enzima (250 mM de Tris- $\mathrm{HCl} \mathrm{pH} 8,3 ; 375 \mathrm{mM}$ de $\mathrm{KCl}, 15 \mathrm{mM}$ de $\mathrm{MgCl}_{2}, 50$ mM DTT), $1 \mu \mathrm{L}$ mistura de dNTPs (10 mM cada; Invitrogen, Corp., Camarillo, CA, USA), 1 $\mu \mathrm{L}$ da enzima M-MLV Reverse Transcriptase (Promega Corp, WI, EUA), em volume final de $20 \mu \mathrm{L}$, completos com $\mathrm{H}_{2} 0$ DEPC, e incubou-se por 1 hora a $42{ }^{\circ} \mathrm{C}$. A inativação ocorreu a $70{ }^{\circ} \mathrm{C}$ por 15 minutos e, após este período, as amostras foram estocadas a $-20{ }^{\circ} \mathrm{C}$ até a realização da próxima etapa.

\subsection{Avaliação da expressão gênica do ${ }_{\beta} F S H$ e do ${ }_{\beta} L H$}

Conforme procedimentos descritos por Nolan (2006), o produto de RT foi diluído e a eficiência da ligação dos primers foi avaliada para se escolher a melhor proporção para o ensaio com as amostras de teste. Para o LH, o coeficiente de determinação (cd) foi de 0,98 e a eficiência, 0,84. Para o FSH, o cd foi de 0,98 e a eficiência foi de 1,11. A eficiência ideal deve 
estar entre 0,8 e 1,2. Após essas verificações, as seguintes diluições dos RTs foram utilizadas: 1:100 (FSH), 1:1.000 (LH) e 1:100 (RPL 19) (Fig. 1.1).

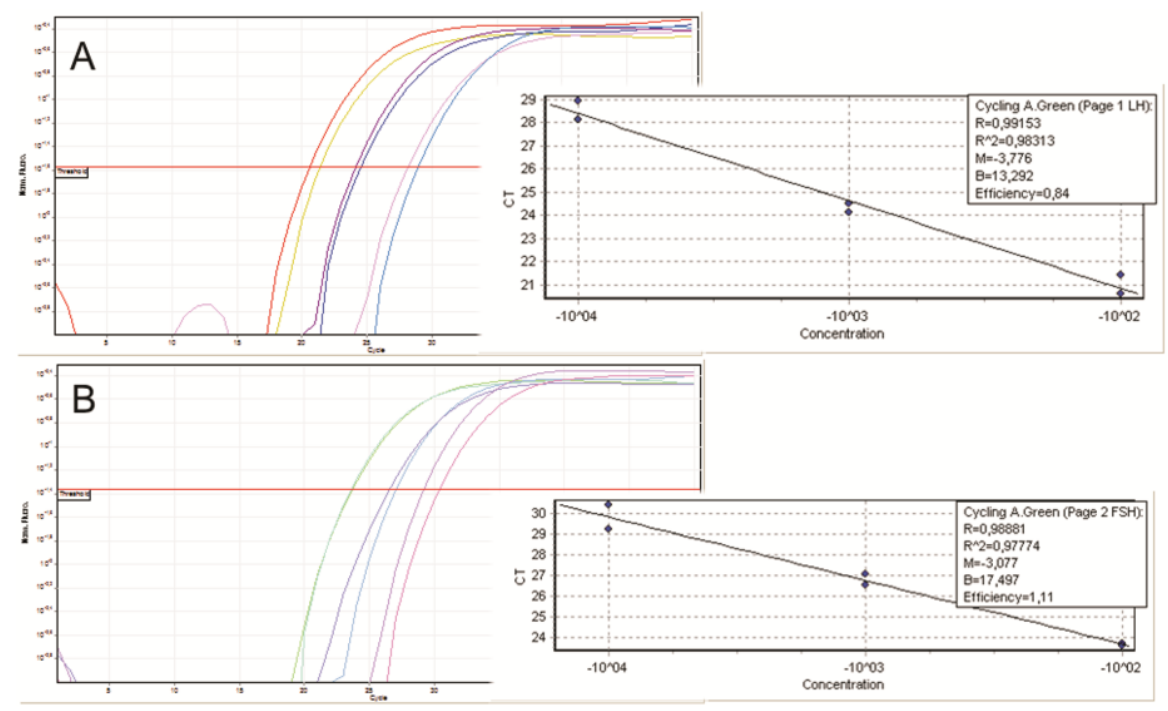

Figura 1.1 - Eficiência de diluição para o estudo do mRNA. As figuras do lado esquerdo mostram a curva de ciclos para as diluições de 1:100, 1:1.000 e 1:10.000 para o LH (A) e FSH (B); as figuras da direita mostram a análise da eficiência dessas diluições.

Seguiu-se a reação utilizando-se o reagente Platinum ${ }^{\circledR} \mathrm{SYBR}^{\circledR}$ green qPCR SuperMix UDG (Invitrogen, Corp., Camarillo, CA, USA) no equipamento Corbett Research (Corbett Life Sciences, Australia). A curva de ciclos/temperatura utilizada foi a seguinte: 2 min a 95 ${ }^{\circ} \mathrm{C}$; e 50 ciclos a $95{ }^{\circ} \mathrm{C}$ por $15 \mathrm{~s}, 60{ }^{\circ} \mathrm{C}$ por 1 min e $72{ }^{\circ} \mathrm{C}$ por $20 \mathrm{~s}$. A especificidade da reação com SYBR ${ }^{\circledR}$ green foi confirmada pela análise da curva de dissociação, tomando-se como base a temperatura de dissociação (melting point), que consiste no aquecimento lento das amostras de $58{ }^{\circ} \mathrm{C}$ (pareamento/alongamento) para $95{ }^{\circ} \mathrm{C}$, e que deve resultar em somente um amplicon por amostra. A presença de mais de um amplicon por amostra indica contaminação com DNA genômico (Fig. 1.2). 

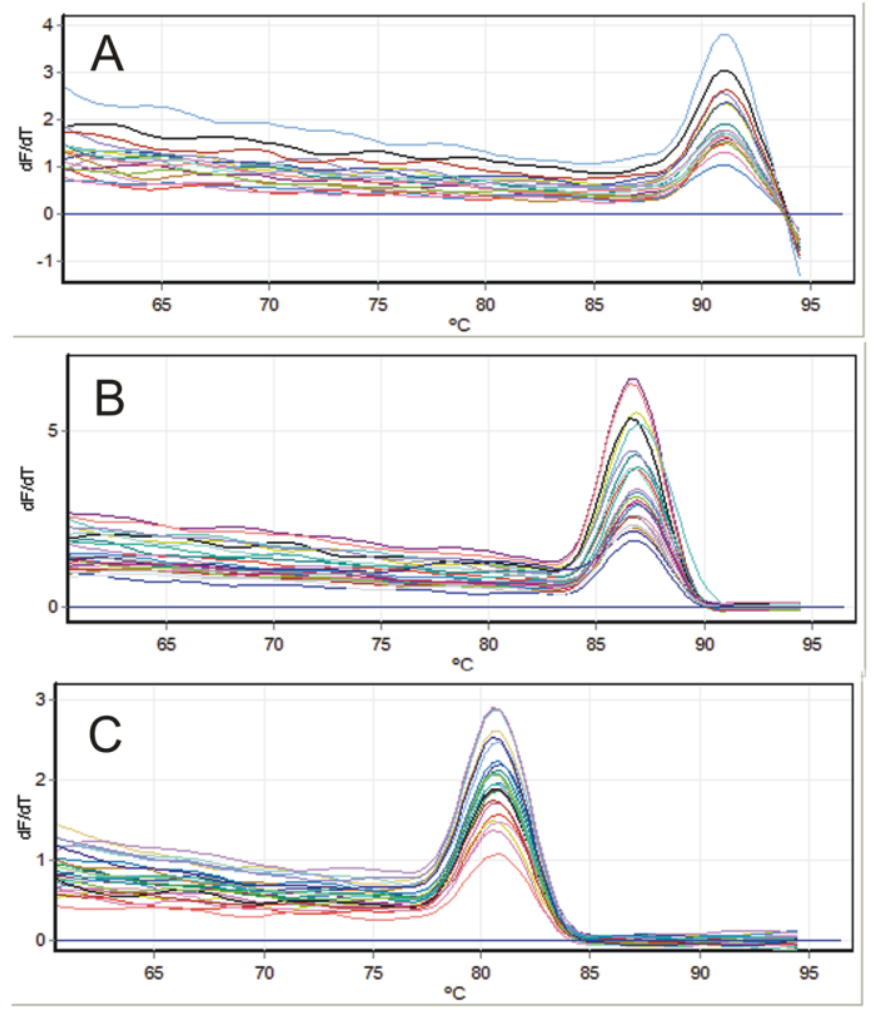

Figura 1.2 - Curva de melt para os ensaios do ${ }_{\beta} \mathrm{LH}(\mathrm{A}),{ }_{\beta} \mathrm{FSH}(\mathrm{B})$ e RPL19 (C). Nos três ensaios podese observar apenas um amplicon, o que é reflexo da especificidade do primer utilizado.

Prosseguiram-se as análises para as amostras de teste com essas diluições, realizandose os ensaios da mesma forma (condições de ciclo/temperatura) que a descrita para a padronização. $\mathrm{O}$ cálculo para a quantificação do mRNA ( $\Delta \Delta \mathrm{Ct}$, cycle threshold) foi desenvolvido conforme Pfaffl (2001). O resultado foi normalizado pelo mRNA RPL19 (constitutivo), na diluição de 1:100 (já previamente padronizado).

1.4.5 Avaliação do grau de poliadenilação do mRNA do ${ }_{\beta} L H$ (RACE-PAT: Rapid Amplification of cDNA ends - Poly A Test)

O tamanho da cauda poli(A) é um dos pré-requisitos para a formação de um mRNA estável, visando à eficiência no seu processo de tradução (GALLIE, 1998). Para análise do estado de poliadenilação desses mRNAs foi utilizado o método RACE-PAT, descrito por Salles et al., 1999 e modificado por Serrano-Nascimento et al. (2010). O RACE-PAT envolve a amplificação da porção terminal 3' do mRNA, onde se localiza a cauda poli-A do mRNA. Esta região é transcrita reversamente, utilizando-se um excesso de oligo(dT) ligado a um 
oligonucleotídeo ancorador (sequência ancoradora de G/C). A fita de DNA formada é submetida ao PCR com um primer específico para o gene de estudo, localizado próximo à região da cauda poli(A) ao sítio de poliadenilação,, e novamente com oligo(dT) ancorador (5' GCGAGCTCCGCGGCCGCGT $_{12}$ ), desta vez servindo como primer antisense para a amplificação.

Esse ensaio é extremamente acurado para a quantificação do comprimento da cauda poli-A, independentemente do tamanho do mRNA. Por fim, como o ensaio RACE-PAT utiliza como primers os oligos(dT), os resultados obtidos indicam, de fato, o estado de poliadenilação do transcrito (SALLÉS et al., 1999). A figura 1.3 exemplifica como os fragmentos são gerados e visualizados por este método.

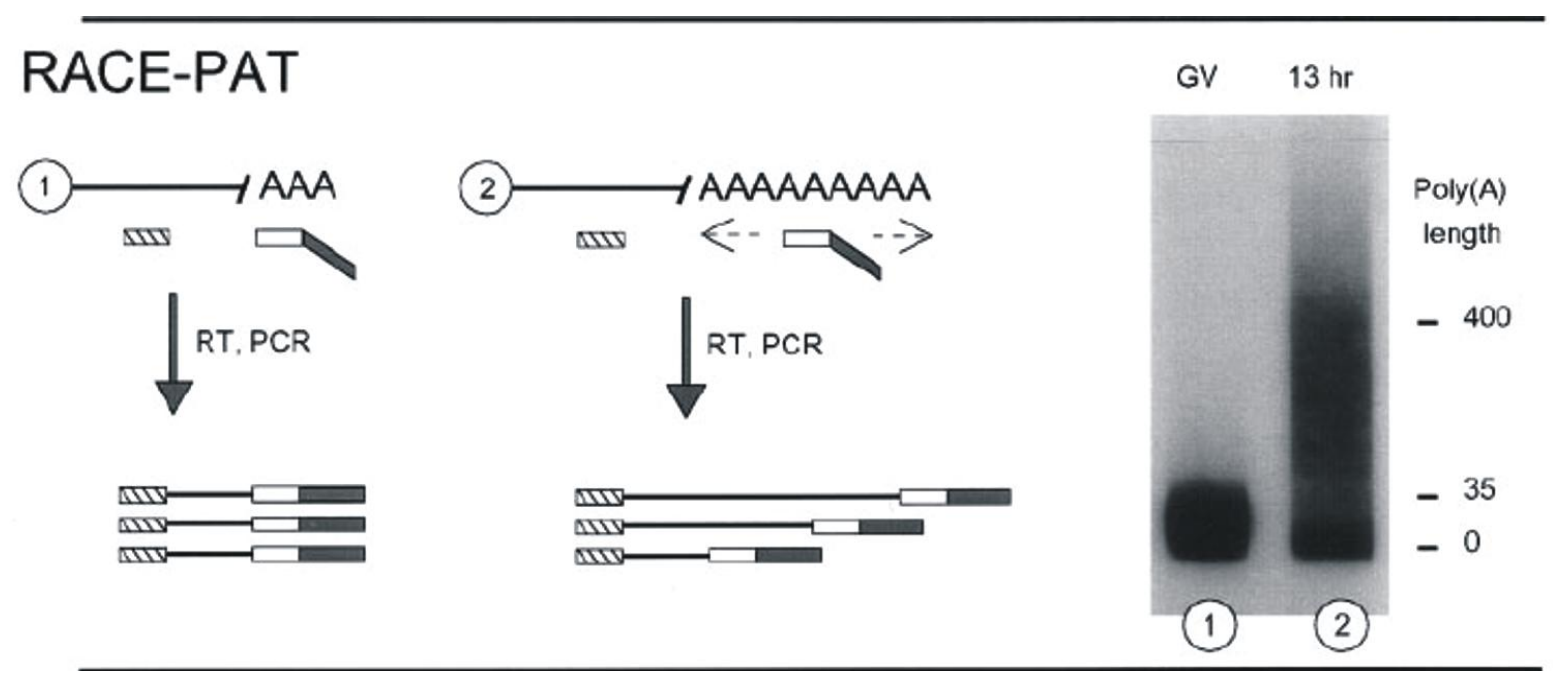

Figura 1.3 - Método de RACE-PAT. A sequência 1 corresponde à amplificação de uma cauda poli(A) com a sequência ancoradora ligando-se a um ponto fixo, próximo ao sítio de poliadenilação gerando fragmentos de tamanho único. Já na sequência 2 , a maior cauda poli-A possibilita que a sequência ancoradora se ligue a diferentes posições, gerando fragmentos de diversos tamanhos. Os fragmentos são visualizados após a eletroforese em gel de agarose a $2,5 \%$, corado com brometo de etídeo e comparados ao peso molecular correspondente

Fonte: Modificado de Sallés et al. (1999).

Para a reação de transcriptase reversa $2 \mu \mathrm{g}$ de RNA foram preincubadas com $200 \mathrm{ng}$ de oligo (dT) âncora (5'-GCGAGCTCCGCGGCCGCG-T 12 ) por 5 minutos a $70{ }^{\circ} \mathrm{C}$, seguido de 1 hora a $42{ }^{\circ} \mathrm{C}$ em um mix contendo $10 \mathrm{mM}$ de cada dNTP, $5 \mathrm{X}$ first-strand buffer, $0,01 \mathrm{M}$ de DTT, $1 \mu \mathrm{l}$ de $200 \mathrm{U} / \mu \mathrm{l}$ de transcriptase reverse MMLV (Invitrogen Life Technologies, Camarillo, CA, USA). 
Três microgramas do produto da reação de RT foram misturados numa reação contendo $25 \mathrm{mM} \mathrm{MgCl}_{2}, 10 \mathrm{mM}$ de cada dNTP, 25 pmol de cada primer (LH: 5'CCAATGACCTGTGACCTTCC e âncora: 5'-GCGAGCTCCGCGGCCGCG-T 12 ), 1,25 U de GoTaq Flexi DNA Polymerase e 5X Green GoTaq Flexi Buffer Migration Pattern (Promega Corp., Madison, WI, EUA). As condições de PCR foram as seguintes: 5 min a $95{ }^{\circ} \mathrm{C}$ (denaturação inicial), seguidos por 40 ciclos de $30 \mathrm{~s}$ a $95{ }^{\circ} \mathrm{C}, 1 \mathrm{~min}$ a $68^{\circ} \mathrm{C}$ (anelamento), 1 min a $72^{\circ} \mathrm{C}$ (extensão), e terminando com 7 min de extensão final a $72^{\circ} \mathrm{C}$. Os produtos de PCR foram analisados eletroforeticamente em gel de agarose-TBE a 2,5\% e corado por brometo de etídeo.

O mínimo fragmento esperado (amplicon) foi de 128 pb e a análise das amostras foi estimada por densitometria e comparada com DNA ladder de 100 pb (Invitrogen Life Technologies, Camarillo, CA, USA), utilizando-se o software ImageMaster 1D-Pharmacia Biotech SW (Pharmacia Biotech, Uppsala, Sweden).

\subsubsection{Perfil polissomal}

A análise do perfil polissomal tem como objetivo central determinar a parcela de um mRNA; no caso, os mRNAs do LH e do FSH, que estão sendo traduzidos no momento estudado, seguindo-se a metodologia abaixo.

As hipófises foram removidas e homogeneizadas em baixa rotação, em tampão de extração contendo Tris- $\mathrm{HCl} 15$ mM ph 7,4, $\mathrm{MgCl}_{2} 15$ mM, NaCl 300 mM, Triton X-100 1\%, ciclohexamida $1 \mathrm{mg} / \mathrm{mL}$, DTT (dithiotheitol) $0,33 \mathrm{mM}$ e heparina $1 \mathrm{mg} / \mathrm{mL}$, reconstituídos em água DEPC. Para cada grupo experimental foi utilizado um pool de 10 hipófises que foram homogeneizadas em $600 \mu \mathrm{L}$ individualmente, ou seja, à medida que foram removidas. Para a preservação dos polissomos, o extrato foi mantido todo o tempo em gelo. Após esse procedimento, o extrato foi centrifugado a $10.000 \mathrm{~g} \mathrm{a} 4{ }^{\circ} \mathrm{C}$ por $10 \mathrm{~min}$. O sobrenadante foi colhido e transferido para outro eppendorf identificado. O conteúdo de ácidos nucléicos do extrato total foi quantificado em comprimento de onda de $260 \mathrm{~nm}$ e, em seguida, $14 \mathrm{U} / \mathrm{mL}$ (unidades de absorbância/mL) da amostra foram aplicadas no topo de um gradiente de sacarose (com 7\% na primeira fase, passando a 7,1\%, 7,2\% até atingir 47\%) contendo: Tris$\mathrm{HCl} 15 \mathrm{mM}$ ph 7,4, $\mathrm{MgCl}_{2} 15 \mathrm{mM}, \mathrm{NaCl} 300 \mathrm{mM}$, ciclohexamida $1 \mathrm{mg} / \mathrm{mL}$, DTT (dithiotheitol) 0,33 mM. O gradiente de sacarose foi montado com auxílio de um aparelho específico (Biocomp-gradiente master ip). Os tubos com as amostras foram balanceados, colocados no rotor SW41Ti (Beckman) e submetidos a ultracentrifugação a 39.000 rpm a 
$4^{\circ} \mathrm{C}$, por tempo correspondente a $02 \mathrm{~h} 30$. Após a ultracentrifugação, as diferentes frações do gradiente foram colhidas em alíquotas de $900 \mu \mathrm{L}$, a partir do topo, por meio de um coletor de frações (model 2110 Bio-Rad) acoplado a um detector de UV em um comprimento de onda de $254 \mathrm{~nm}$, com auxílio de uma bomba peristáltica injetando sacarose a 60\% na base do tubo (que continha a sacarose a $47 \%$ ).

As alíquotas das amostras colhidas a partir do gradiente de sacarose foram descongeladas em gelo, diluídas em $2 \mathrm{~mL}$ de tiocianato de guanidina $4 \mathrm{M}$ e $3 \mathrm{~mL}$ de etanol $100 \%$, incubadas a $-20{ }^{\circ} \mathrm{C}$ overnight. Os RNAs foram precipitados através de centrifugação a $10.000 \mathrm{~g}$ a $4{ }^{\circ} \mathrm{C}$ por $30 \mathrm{~min}$, o sobrenadante foi desprezado e os pellets, lavados em etanol $75 \%$ e mantidos a $4{ }^{\circ} \mathrm{C}$ por $30 \mathrm{~min}$. Cada pellet foi ressuspenso em $400 \mu \mathrm{L}$ de água DEPC por agitação mecânica, aquecido a $65{ }^{\circ} \mathrm{C}$ por $15 \mathrm{~min}$ e transferido para um eppendorf devidamente identificado, ao qual foram acrescentados $50 \mu \mathrm{L}$ de acetato de sódio $2 \mathrm{M} \mathrm{pH} \mathrm{4,0,}$ $1 \mathrm{~mL}$ de etanol 100\% e 7,5 $\mu \mathrm{L}$ de heparina (40 mg/mL). Após a centrifugação a $13.000 \mathrm{rpm}$ (Eppendorf model 5415R) a $4{ }^{\circ} \mathrm{C}$ por 20 min, o sobrenadante foi desprezado e o pellet lavado com $500 \mu \mathrm{L}$ de etanol 75\%. As amostras contendo os RNAs foram centrifugadas a $10.000 \mathrm{~g} \mathrm{a}$ $4{ }^{\circ} \mathrm{C}$ por $5 \mathrm{~min}$, secas por 6 min em Speed-Vack e submetidas aos procedimentos de PCR em tempo real, utilizando-se os mesmos primers, diluições e curva de temperatura descritos anteriormente.

\subsubsection{Expressão protéica do ${ }_{\beta} \mathrm{LH}$ e do ${ }_{\beta} \mathrm{FSH}$ (Western Blotting)}

\subsubsection{Extração da proteína total}

As hipófises foram homogeneizadas individualmente em $300 \mu \mathrm{L}$ de tampão contendo 0,25 M de sacarose, $2 \mathrm{mM} \mathrm{MgCl}_{2}$ e $20 \mathrm{mM}$ de Tris- $\mathrm{HCl}$ e, após centrifugação por $10 \mathrm{~min}$ a $100 \mathrm{~g} \mathrm{a} 4{ }^{\circ} \mathrm{C}$, o sobrenadante foi transferido para outro eppendorf e o pellet ressuspendido em $200 \mu \mathrm{L}$ do tampão. Após nova centrifugação nas mesmas condições, o sobrenadante foi adicionado à fração transferida anteriormente, sendo a amostra resultante centrifugada a $800 \mathrm{~g}$ por 10 min a $4{ }^{\circ} \mathrm{C}$. O sobrenadante obtido foi transferido para um eppendorf novo, e seguiu-se a quantificação protéica. 


\subsubsection{Quantificação protéica}

A quantificação foi realizada pelo método de Bradford (1976) (Dye Reagent Concentrate, Bio-Rad Laboratories Inc., USA). As amostras e o reagente de Bradford foram diluídos na proporção de 1:5 em água deionizada. A curva foi calculada a partir de amostras de albumina sérica bovina, nas concentrações de 0,2-0,4-0,6-0,8-1,0 $\mu \mathrm{g} / \mu \mathrm{L}$. Aplicaram-se 6 $\mu \mathrm{L}$ de cada amostra nos fossos da placa de Elisa, em triplicata para as amostras e em duplicata para a curva e $300 \mu \mathrm{L}$ de reagente de Bradford diluído. A placa foi deixada por 10 min no escuro e procedeu-se a leitura em espectrofotômetro a $595 \mathrm{~nm}$.

\subsubsection{Preparo das alíquotas para aplicação no gel}

Após a leitura, $30 \mu \mathrm{g}$ de cada amostra foram aliquotadas e liofilizadas. Adicionou-se à alíquota $1 \mu \mathrm{L}$ de Laemmli $(62,5 \mathrm{mM}$ de Tris- $\mathrm{HCl} \mathrm{pH}$ 6,8; $20 \%$ de glicerol; $10 \%$ de mercaptoetanol; 4\% SDS; $0,08 \%$ de bromofenol blue) e $1 \mu \mathrm{L}$ de Tris totalizando $20 \mu \mathrm{L}$ por amostra; colocou-se em banho fervente por 10 min e aplicou-se no gel.

\subsubsection{Preparo do gel de poliacrilamida e eletroforese das amostras}

O gel para o ensaio de Western Blotting consiste de duas fases: gel de stacking (ou de empacotamento), que possibilita o alinhamento das proteínas, preparado à base de poliacrilamida a 6\%, e o gel de separação, preparado a 15\%, além de Tris pH 8,8, SDS 20\%, persulfato de amônia (APS), Temed e água deionizada.

Após a aplicação das amostras no gel, a eletroforese iniciou-se a $40 \mathrm{mV}$ até a completa saída das amostras das casas e completou-se a $90 \mathrm{mV}$. O tampão de eletroforese utilizado foi elaborado à base de Tris-base $25 \mathrm{mM}, 193 \mathrm{mM}$ de glicina, 0,1\% de SDS e água destilada.

\subsubsection{Transferência das amostras do gel para a membrana}

Após o término da eletroforese, o sistema foi retirado da cuba, o gel desmontado e remontado no sistema de transferência. O suporte para a transferência foi preenchido por duas esponjas, dois pedaços de papel Whatman, o gel invertido, a membrana de nitrocelulose, mais dois pedaços de papel Whatman e duas esponjas embebidas em tampão de transferência (Trisbase $25 \mathrm{mM}, 192 \mathrm{mM}$ de glicina, metanol $20 \%$ e água destilada). O sistema foi fechado, 
colocado na cuba de transferência Semi-Dry (Bio-Rad Laboratories Inc., USA) a 15 mV por uma hora.

O sistema foi desmontado, o gel foi corado com staining solution por $30 \mathrm{~min}$ e colocado em solução descorante por três dias. A membrana foi corada com Ponceau por um minuto, lavada com PBS $1 \mathrm{X} /$ Tween $0,1 \%$ e dividida em duas porções, uma que contém proteínas a partir de $40 \mathrm{kDa}$ e outra com as proteínas de peso molecular inferior a $40 \mathrm{kDa}$.

\subsubsection{Incubações}

\subsubsection{1 ${ }_{\beta} L H$}

A membrana foi pré-incubada com tampão de bloqueio (5\% leite em pó desnatado, 2,7 $\mathrm{mM} \mathrm{KCl}, 137 \mathrm{mM} \mathrm{NaCl}, 8 \mathrm{mM}$ NaHPO4, 1,4 mM KPO4, e 0,1\% Tween 20) overnight a $4{ }^{\circ} \mathrm{C}$ para reduzir ligações inespecíficas. Seguiu-se incubação a temperatura ambiente por $3 \mathrm{~h}$ com anticorpo anti-LH de rato gerado em coelho (1:1.500, NIDDKD, National Hormone and Pituitary Program, National Institute of Diabetes and Digestive and Kidney Diseases, Torrance, CA, USA) diluído em $5 \%$ de leite em pó desnatado, $2,7 \mathrm{mM} \mathrm{KCl}, 137 \mathrm{mM} \mathrm{NaCl}, 8$ mM NaHPO4, 1,4 mM KPO4, e 0,1\% Tween 20.

\subsubsection{2 ${ }_{\beta} F S H$}

A membrana foi pré-incubada com tampão de bloqueio, conforme descrito, seguindose incubação em temperatura ambiente por $3 \mathrm{~h}$, com anticorpo anti-FSH de rato gerado em coelho (1:500, NIDDKD) diluído em 2,7 mM KCl, 137 mM NaCl, 8 mM NaHPO $4,1,4 \mathrm{mM}$ $\mathrm{KPO}_{4}$, e 0,1\% Tween 20.

\subsection{GAPDH}

A membrana foi pré-incubada com tampão de bloqueio, conforme descrito, seguindose incubação overnight a $4{ }^{\circ} \mathrm{C}$ com anticorpo anti-GAPDH de rato gerado em camundongo (1:1.000, Santa Cruz Biotechnology, Santa Cruz, CA, USA), em 2,7 mM KCl, 137 mM NaCl, $8 \mathrm{mM} \mathrm{NaHPO}_{4}, 1,4 \mathrm{mM} \mathrm{KPO}_{4}$, e 0,1\% Tween 20. A proteína GAPDH foi escolhida como constitutiva. 


\subsubsection{Detecção das bandas e quantificação}

A detecção das bandas foi realizada utilizando-se anticorpo secundário conjugado à peroxidase, elaborado conforme a espécie empregada na confecção do anticorpo primário (1:5.000; Santa Cruz Biotechnology, Santa Cruz, CA, USA) em 2,7 mM KCl, 137 mM NaCl, $8 \mathrm{mM} \mathrm{NaHPO}_{4}, 1,4 \mathrm{mM} \mathrm{KPO}_{4}$, e 0,1\% Tween 20 buffer, por $1 \mathrm{~h}$ em temperatura ambiente, e kit ECL (Amersham Biosciences, Buckinghamshire, UK). Os blots foram analisados com o software Image J 1.42q (National Institutes of Health, NIH, USA). Os dados foram normalizados com o GAPDH e os resultados expressos em unidades arbitrárias (UA).

\subsubsection{Imunohistoquímica}

As hipófises foram fixadas por 30 minutos em paraformaldeído a 2\% em PBS (2.7mM $\mathrm{KCl}, 137 \mathrm{mM} \mathrm{NaCl}, 8 \mathrm{mM}$ NaHPO4, 1.4mM KPO4), emblocadas em Tissue Freezing Medium (Triangle Biomedical Sciences, Durham, NC, USA) e rapidamente congeladas a $-80{ }^{\circ} \mathrm{C}$ imersas em 2-Metilbutano (CAS 78-78-4, Spectrum, Gardena, CA, USA). Os cortes de $5 \mu \mathrm{m}$ foram obtidos em criostato, posicionados em lâminas previamente gelatinizadas e secos em estufa a $37{ }^{\circ} \mathrm{C}$ por uma hora. Para a padronização, foram utilizados cortes de todos os segmentos da hipófise e não foram observadas diferenças regionais na localização dos gonadotrofos.

Os sítios não-específicos foram bloqueados com soro normal de cabra diluído 1:1 em PBS/BSA $10 \%$ por $1 \mathrm{~h}$, em temperatura ambiente. A incubação com anticorpo secundário anti-rato FSH ou LH (1:100 diluído em PBS/TWEEN 20 0.3\%) foi realizada overnight a $4{ }^{\circ} \mathrm{C}$. Seguiram-se três lavagens em PBS por 3 min e incubação com anticorpo secundário conjugado com FITC (Fluorescein isothiocyanate conjugated; 1:200, SIGMA-ALDRICH Inc, Saint Louis, MO, USA) por 90 min em temperatura ambiente. Os cortes foram lavados novamente sob as mesmas condições anteriores e seguiu-se a coloração para actina-F, utilizando-se faloidina-rodamina (1:40, Invitrogen Life Technologies, Camarillo, CA, USA) por $60 \mathrm{~min}$ em temperatura ambiente. Os cortes foram cobertos com Prolong ${ }^{\circledR}$ Gold com DAPI (4,6-diamino-2-phenylindole) (Invitrogen Life Technologies, Camarillo, CA, USA) para coloração nuclear, montagem com lamínula e vedação com esmalte.

O microscópio Nikon Eclipse E600 foi utilizado para a observação dos cortes. As imagens foram capturadas com o auxílio de uma câmera digital (Cool SNAP-Procf color; 
Roper Scientific, Trenton, New Jersey, USA) e do software Image Pro Plus (Media Cybernetics, Silver Spring, Maryland, USA).

1.4.9 Análise da expressão do mRNA do receptor de andrógenos (AR) e do receptor de LH (LHR)

A expressão dos mRNAs dos receptores de LH foi estudada nos testículos e a expressão do receptor de andrógenos foi estudada nos testículos e nas três porções epididimais. A metodologia para o estudo destes genes envolveu a construção dos primers específicos, extração do RNA total e PCR em tempo real (RTqPCR). O detalhamento dessas metodologias está apresentado nos subitens a seguir.

\subsubsection{Elaboração dos primers específicos}

O procedimento foi o mesmo utilizado anteriormente para a elaboração dos primers de LH e FSH, utilizando-se as seguintes sequências gênicas:

- NM_012502.1 Rattus norvegicus androgen receptor (Ar)

- NM_012978.1 Rattus norvegicus luteinizing hormone/choriogonadotropin receptor (Lhcgr)

Os primers utilizados estão demonstrados no Quadro 1.2. 
Quadro 1.2-Primers sense e antisense utilizados para o ensaio de realtime PCR

\begin{tabular}{|cc|}
\hline Primers & Sequência \\
\hline Sense: AR & 5'-GCCATGGGTTGGCGGTCCTT -3' \\
Antisense: AR & 5'- AGGTGCCTCATCCTCACGCACT -3' \\
Sense: LHR & 5'-AGTGGAGCCTTCCAGGGGGC -3' \\
Antisense: LHR & 5'- AGGAAGACAGGGCGATGAGCGT -3' \\
Sense: RPL19 & 5'-AGTATGCTTAGGCTACAGAA-3' \\
Antisense: RPL19 & 5'-TCCCTTAGACCTGCTTGGTC-3' \\
\hline
\end{tabular}

\subsubsection{Extração do RNA total}

As amostras de testículos e epidídimos foram pulverizadas em nitrogênio líquido e uma porção (30 mg de tecido) depositada num tubo tipo eppendorff de 2,0 mL e submetida à extração do RNA total, baseada na metodologia da guanidina-fenol-clorofórmio e precipitação com isopropanol (CHOMCZYNSKI et al., 1987), conforme procedimentos já descritos previamente.

\subsubsection{PCR quantitativo em tempo real (RTqPCR)}

\subsection{Síntese do cDNA para o RTqPCR}

A partir de $1 \mu \mathrm{g}$ do RNA total, foi realizado o ensaio de reação de transcrição reversa (RT) com oligo(dT) para a síntese de uma fita de DNA complementar ao mRNA (ssDNA), conforme procedimentos já descritos anteriormente.

\subsection{Avaliação da expressão gênica do AR, LHR e RPL 19 nos testículos}

Conforme procedimentos descritos por Nolan (2006), o produto da reação de RT foi diluído e a eficiência da ligação dos primers foi avaliada para se escolher a melhor proporção para o ensaio com as amostras de teste. Para o AR, o coeficiente de determinação (cd) foi de 
0,98 e a eficiência 0,90 (Fig. 1.4 A). Para o rLH, o cd foi de 0,98 e a eficiência de 1,11 (Fig. 1.4 B). Para o RPL 19 (constitutiva), o cd foi de 0,99 e a eficiência de 0,82 (Fig. 1.4 C). A eficiência ideal deve estar entre 0,8 e 1,2. As diluições utilizadas para todas as amostras foram: concentrado, 1:5, 1:10 e 1:20; sendo que os quatro genes obtiveram melhor resultado na diluição 1:10, que foi a escolhida para o prosseguimento dos ensaios com os grupos experimentais.

Seguiu-se a reação utilizando-se o reagente Platinum ${ }^{\circledR} \mathrm{SYBR}^{\circledR}$ green qPCR SuperMix UDG (Invitrogen, Corp., Camarillo, CA, USA) no equipamento Corbett Research (Corbett Life Sciences, Australia) na mesma curva de ciclos/temperatura utilizada para o LH e FSH.. A curva de melt está representada na Fig. 1.5. 

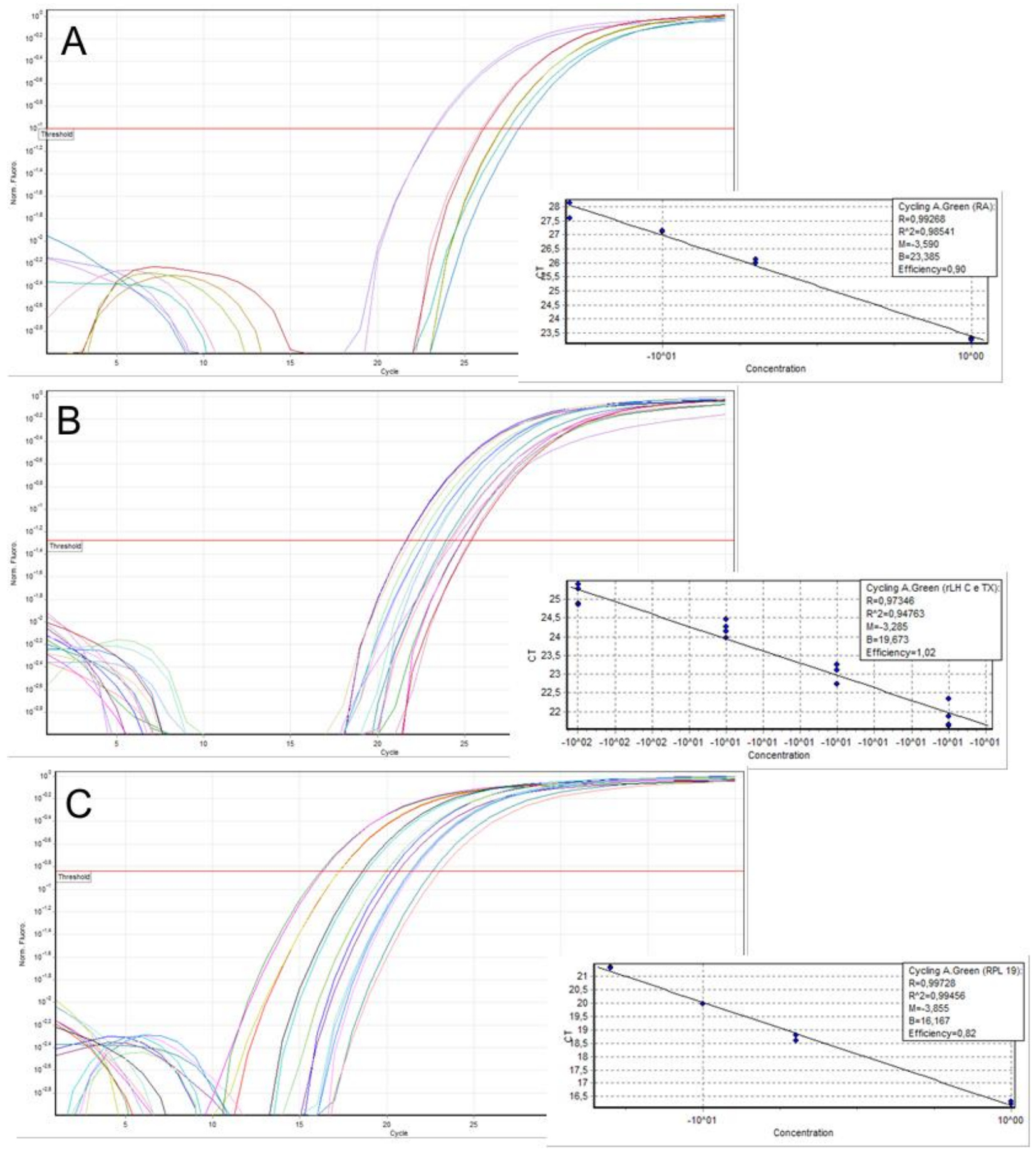

Figura 1.4 - Eficiência de diluição para o estudo do mRNA para os genes de AR (A), LHR (B) e RPL 19 (C) em amostras de testículos. A figura da esquerda representa a curva de ciclos e a da direita a equação de eficiência dos primers. 

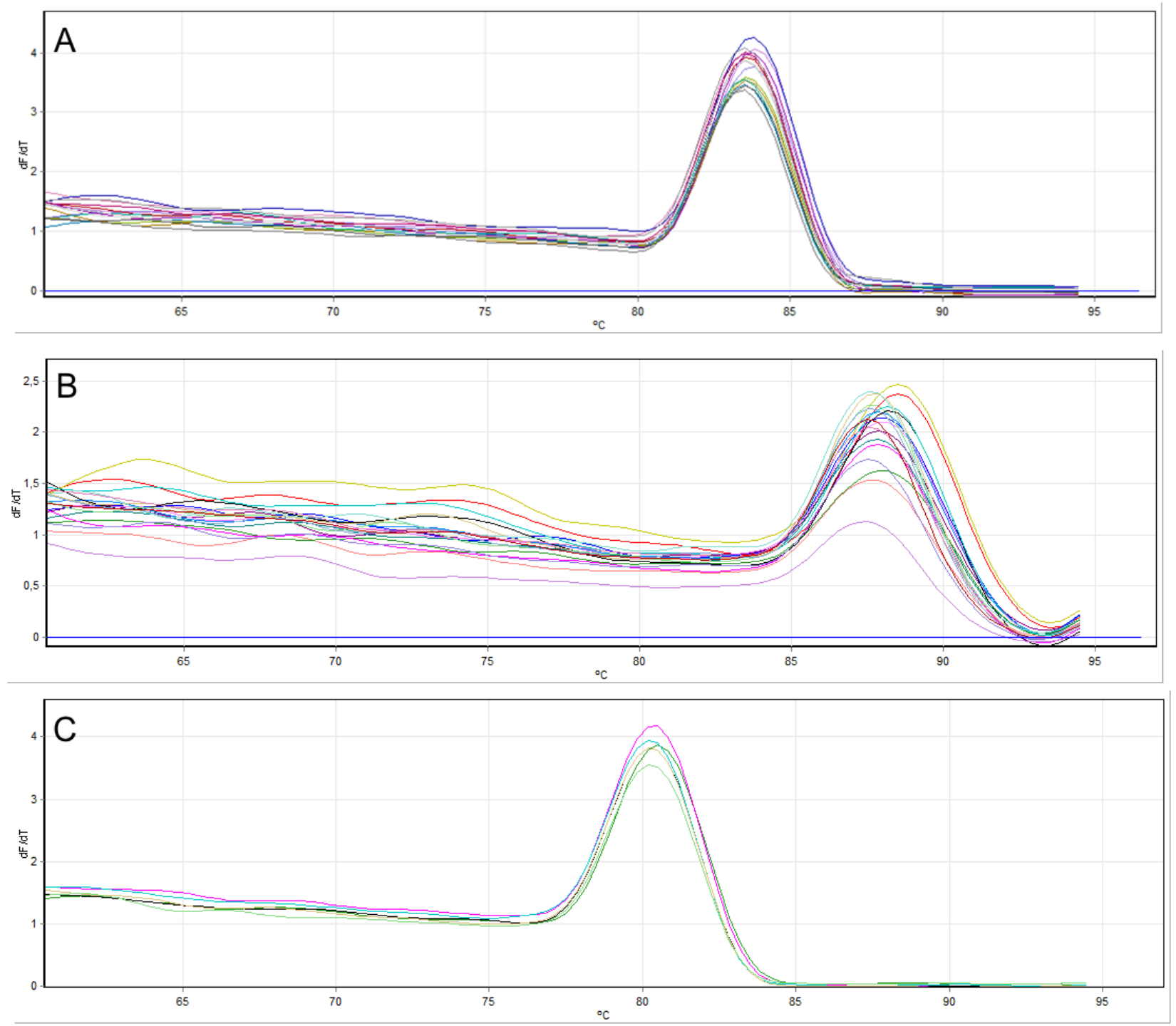

Figura 1.5 - Curva de melt para os ensaios do AR (A), LHR (B) e RPL 19 (C) em amostras de testículos. Nos três ensaios pode-se observar apenas um amplicon, o que é reflexo da especificidade do primer utilizado

Prosseguiram-se as análises para as amostras de teste com essas diluições, realizandose os ensaios da mesma forma (condições de ciclo/temperatura) que a descrita para a padronização. O cálculo para a quantificação do mRNA ( $\Delta \Delta \mathrm{Ct}$, cycle threshold) foi desenvolvido conforme Pfaffl (2001). O resultado foi normalizado pelo mRNA RPL19. 


\subsection{Avaliação da expressão gênica do AR e RPL 19 na cabeça, corpo e cauda do epidídimo}

Os procedimentos foram realizados da mesma forma que para os genes estudados nos testículos. A eficiência dos primers esteve entre 0,8 e 1,2 para todos os genes. As diluições utilizadas dos produtos de RT foram: concentrado, 1:5, 1:10 e 1:20; sendo que os quatro genes obtiveram melhor resultado na diluição 1:5, que foi a escolhida para o prosseguimento dos ensaios com os grupos experimentais.

As figuras 1.6 e 1.8 representam a curva de ciclos e cálculo da eficiência dos primers e as figuras 1.7 e 1.9 representam a curva de melt para o AR e RPL 19 para cabeça (A), corpo (B) e cauda (C) do epidídimo, respectivamente.

Prosseguiram-se as análises para as amostras de teste com essas diluições, realizandose os ensaios da mesma forma (condições de ciclo/temperatura) que a descrita para a padronização. 

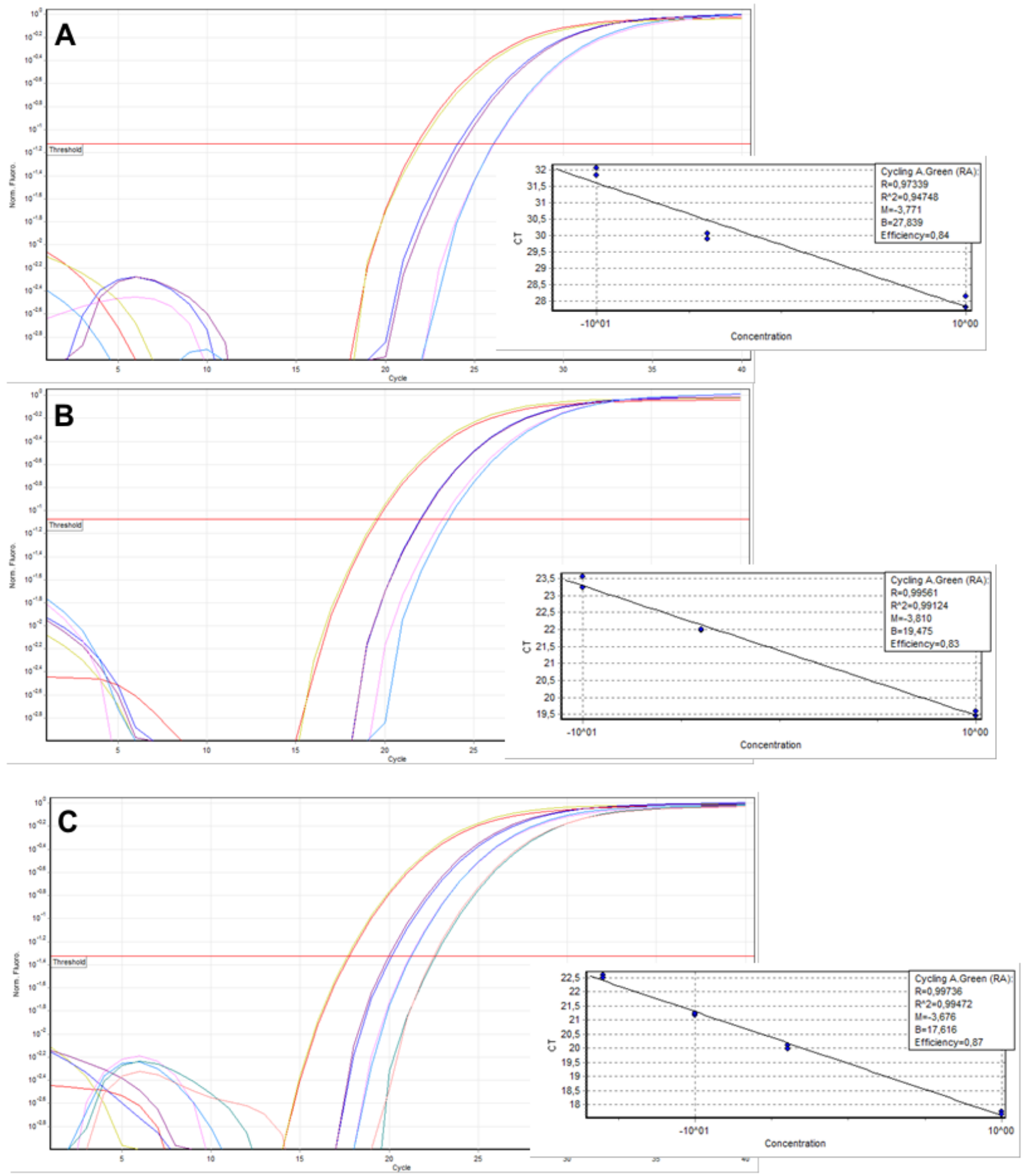

Figura 1.6 - Eficiência de diluição para o estudo do mRNA para o gene de AR em amostras de cabeça (A), corpo (B) e cauda (C) do epidídimo. A figura da esquerda representa a curva de ciclos, e a da direita, a equação de eficiência dos primers. 

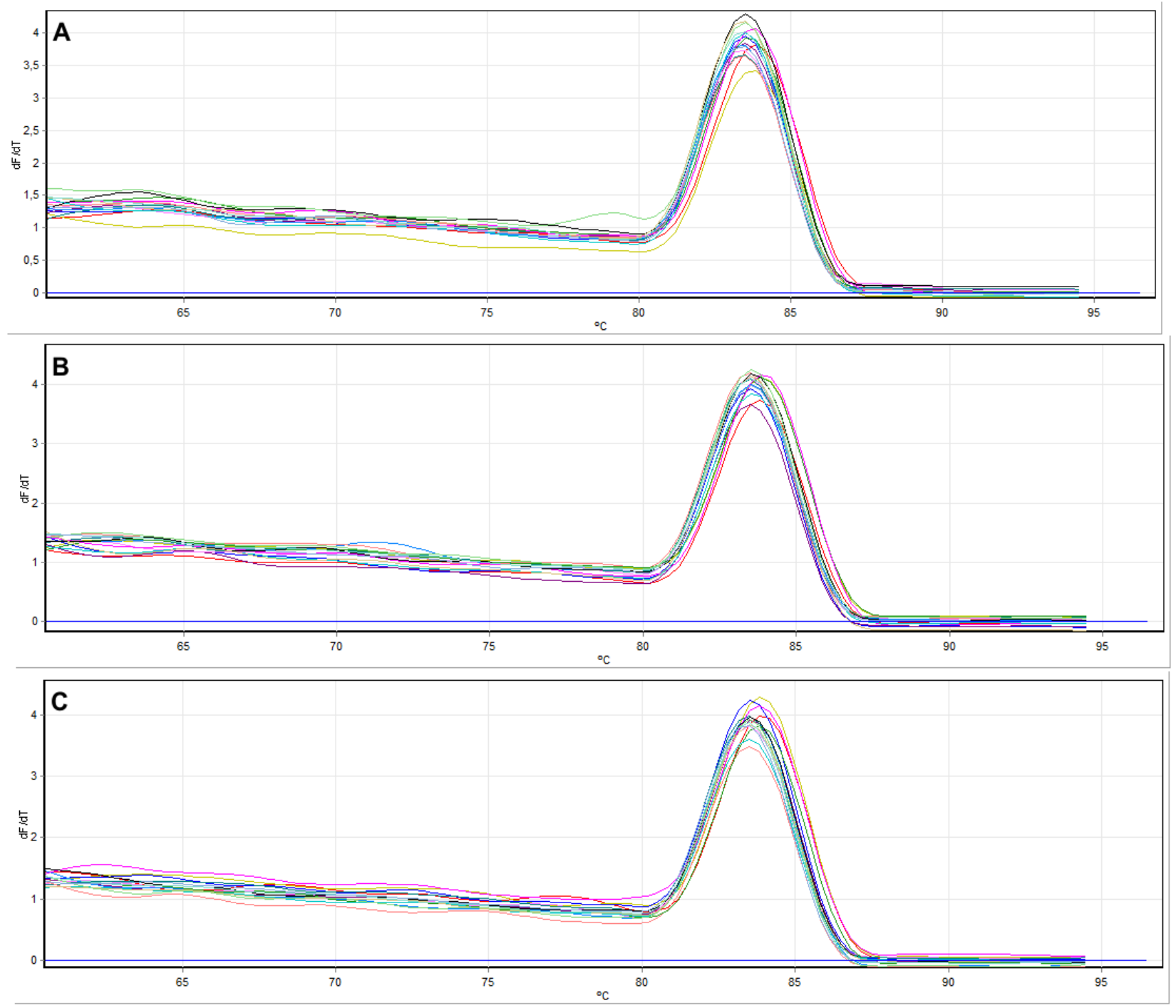

Figura 1.7 - Curva de melt para os ensaios do AR em amostras de cabeça (A), corpo (B) e cauda (C) do epidídimo Nos três ensaios pode-se observar apenas um amplicon, o que é reflexo da especificidade do primer utilizado. 

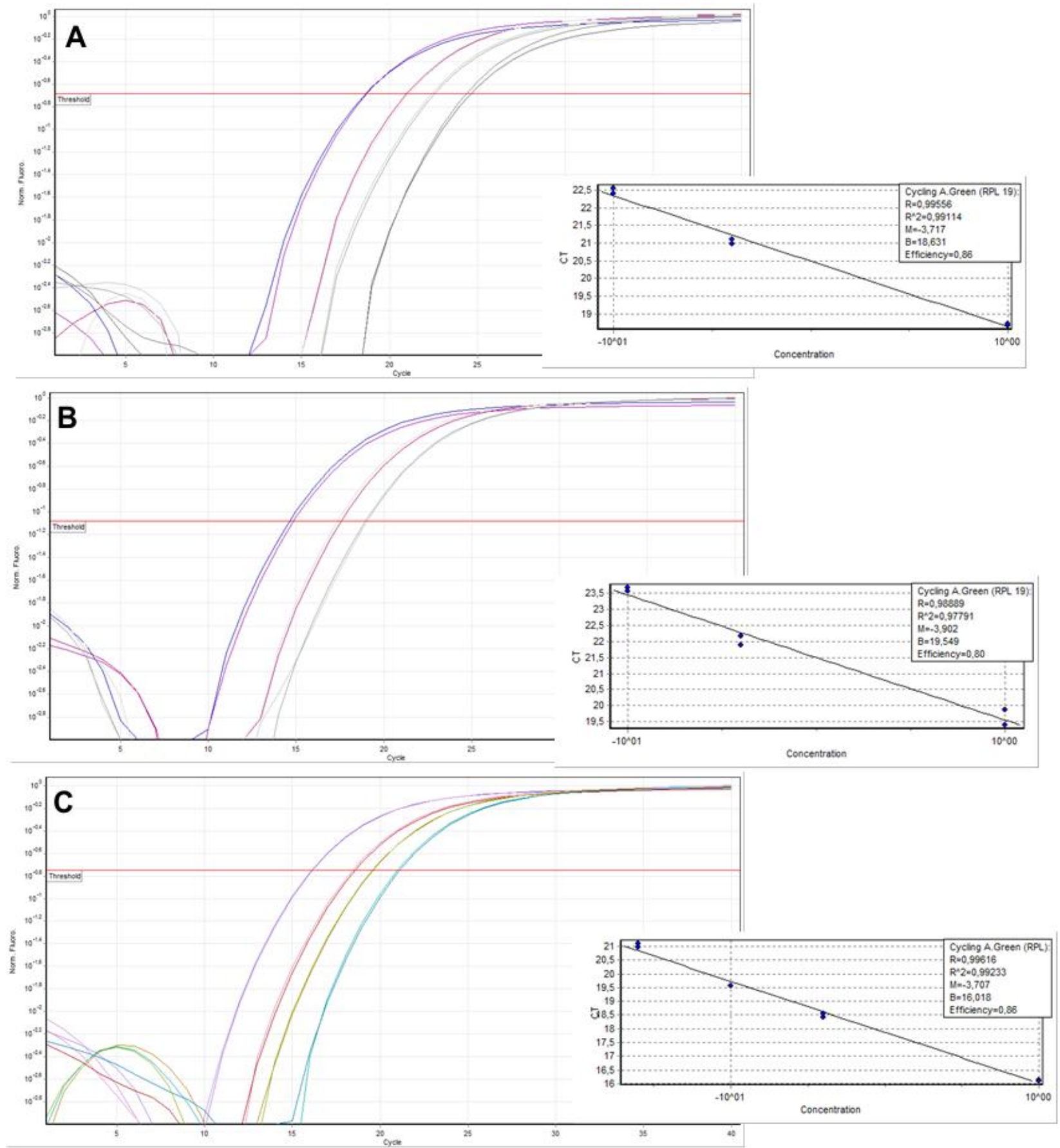

Figura 1.8 - Eficiência de diluição para o estudo do mRNA para o gene de RPL 19 em amostras de cabeça (A), corpo (B) e cauda (C) do epidídimo. A figura da esquerda representa a curva de ciclos, e a da direita, a equação de eficiência dos primers. 

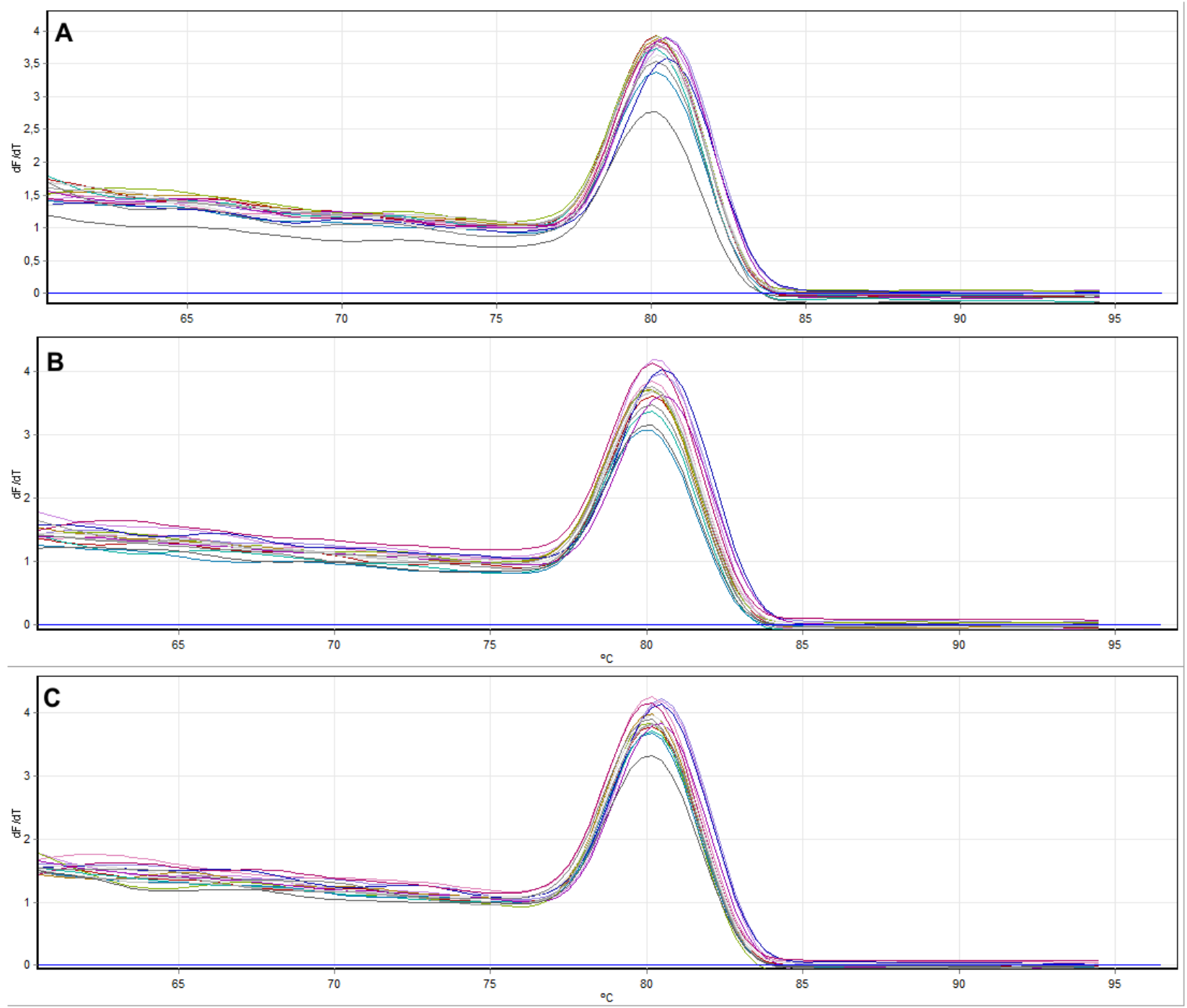

Figura 1.9 - Curva de melt para os ensaios do gene de RPL 19 em amostras de cabeça (A), corpo (B) e cauda (C) do epidídimo. Nos três ensaios pode-se observar apenas um amplicon, o que é reflexo da especificidade do primer utilizado. 
1.4.10 Análise da expressão protéica do receptor de andrógenos (AR) e do receptor de LH (LHR) por Western blotting

\subsubsection{Extração de proteínas totais e quantificação protéica}

Os testículos e os segmentos de epidídimo foram pulverizados em nitrogênio líquido e uma fração (80 a $120 \mu \mathrm{g}$ ) foi homogeneizada em tampão RIPA (3 $\mu \mathrm{L} / \mathrm{mg}$ tecido; 1\% NP-40, $\mathrm{v} / \mathrm{v}, 0.5 \%$ sodium deoxicolate, $\mathrm{v} / \mathrm{v}, 0,1 \%$ sodium duodecyl sulphate, w/v em PBS) adicionado de inibidores de proteases $(20 \mu \mathrm{g} / \mathrm{mL}$ leupeptin, $10 \mu \mathrm{g} / \mathrm{mL}$ aprotinin, $10 \mu \mathrm{g} / \mathrm{mL}$ pepsptatin $\mathrm{A}$, $1 \mathrm{mM}$ phenylmethylsulfonil fluoride, $0,5 \mathrm{mM}$ pefabloc) e $5 \mathrm{mM}$ DTT no gelo, em homogeneizador tipo dounce. Seguiu-se incubação a $4{ }^{\circ} \mathrm{C}$ por $30 \mathrm{~min}$. As amostras foram centrifugadas duas vezes a $10.000 \mathrm{~g}$ por $10 \mathrm{~min}$. $\mathrm{O}$ sobrenadante foi aliquotado $\mathrm{e}$ imediatamente congelado a $-70{ }^{\circ} \mathrm{C}$ para as posteriores análises.

A quantificação foi realizada pelo método de Bradford (Dye Reagent Concentrate, Bio-Rad Laboratories Inc., USA) como previamente descrita para os extratos protéicos de hipófises.

\subsubsection{Preparo das alíquotas para aplicação no gel}

Após a leitura, $100 \mu \mathrm{g}$ de cada amostra foram diluídas em $20 \mu \mathrm{L}$ de tampão Laemmli (62,5 mM de Tris-HCl pH 6,8; $20 \%$ de glicerol; $10 \%$ de mercaptoetanol; 4\% SDS; 0,08\% de bromofenol blue) e $1 \mu \mathrm{L}$ de Tris, e colocadas em banho fervente por $10 \mathrm{~min}$ e aplicou-se no gel.

\subsubsection{Preparo do gel de poliacrilamida e eletroforese das amostras}

O gel de stacking foi à base de poliacrilamida a $4 \%$ e o gel de separação a $8 \%$. Após a aplicação das amostras no gel, a eletroforese iniciou-se a $40 \mathrm{mV}$, até a completa saída das amostras das casas, e completou-se a $90 \mathrm{mV}$. O tampão de eletroforese utilizado foi elaborado à base de Tris-base $25 \mathrm{mM}, 193 \mathrm{mM}$ de glicina, 0,1\% de SDS e água destilada. 


\subsubsection{Transferência das amostras do gel para a membrana}

Após o término da eletroforese, o sistema foi retirado da cuba, o gel desmontado e remontado no sistema de transferência. $\mathrm{O}$ suporte para a transferência foi preenchido por duas esponjas, papel Whatman, o gel invertido, a membrana de PVDF (previamente ativada em metanol por 15 segundos), papel Whatman e duas esponjas, embebidas em tampão de transferência (Tris-base 25 mM, 192 mM de glicina, metanol 20\% e água destilada ). O sistema foi fechado, colocado na cuba de transferência Semi-Dry (Bio-Rad Laboratories Inc., USA) a $15 \mathrm{mV}$ por uma hora.

O sistema foi desmontado, o gel foi corado com staining solution por 30 minutos e colocado em solução descorante por três dias. A membrana foi corada com Ponceau por um minuto, lavada com PBS $1 \mathrm{X} /$ Tween $0,1 \%$.

\subsubsection{Incubações}

\subsection{Receptor de $\mathrm{LH}$}

A membrana foi preincubada com tampão de bloqueio (3\% BSA, $5 \mathrm{mM}$ Tris -HCL pH 7,5, $150 \mathrm{mM} \mathrm{NaCl}, 0,5 \%$ Tween 20 e 0,5\% NP-40) por 2 h a TA. Seguiu-se incubação overnight a $4{ }^{\circ} \mathrm{C}$ com anticorpo anti-receptor de LH (1:200, anti-LH receptor H-50, Santa Cruz, CA, USA) diluído em 1\% BSA, 5 mM Tris -HCL pH 7,5, $150 \mathrm{mM} \mathrm{NaCl,} \mathrm{0,5 \%} \mathrm{Tween}$ 20 e $0,5 \%$ NP-40.

\subsection{Receptor de andrógenos}

A membrana foi preincubada com tampão de bloqueio (3\% BSA, $5 \mathrm{mM}$ Tris -HCL pH 7,5, $150 \mathrm{mM} \mathrm{NaCl}, 0,5 \%$ Tween 20 e 0,5\% NP-40) por 2 h a TA. Seguiu-se incubação com anticorpo anti-receptor de andrógenos (1:300 para as amostras de testículos e 1:600 para as amostras de epidídimos, anti-AR N-20, Santa Cruz, CA, USA) diluído em 1\% BSA, 5 mM Tris -HCL pH 7,5, $150 \mathrm{mM} \mathrm{NaCl,} \mathrm{0,5 \%} \mathrm{Tween} 20$ e 0,5\% NP-40. 


\subsection{Alfa-actinina}

A membrana foi preincubada com tampão de bloqueio, conforme descrito, seguindose incubação overnight a $4{ }^{\circ} \mathrm{C}$ com anticorpo anti-alfa actinina (1:1.000, Santa Cruz Biotechnology, Santa Cruz, CA, USA), diluído em 1\% BSA, 5 mM Tris -HCL pH 7,5, 150 $\mathrm{mM} \mathrm{NaCl}, 0,5 \%$ Tween 20 e $0,5 \%$ NP-40.

\subsubsection{Detecção das bandas e quantificação}

A detecção das bandas foi realizada da mesma forma que para o LH e FSH.

\subsubsection{Histologia dos túbulos seminíferos}

Amostras de testículos de animais dos grupos controle e tireoidectomizado foram colhidas para estudo histológico. Assim que retirados do animal, os testículos foram fixados em solução de Bouin por $8 \mathrm{~h}$ e incluídos em parafina (protocolo convencional). Os blocos foram então cortados em micrótomo na espessura de $5 \mu \mathrm{m}$, os cortes colocados sobre lâmina e corados por hematoxilina e eosina.

Esses cortes foram submetidos à morfometria linear dos túbulos seminíferos, realizada pela mensuração do diâmetro tubular (medida considerada da lâmina basal até a outra lâmina basal no sentido oposto), espessura epitelial (da lâmina basal até o final da cabeça das espermátides alongadas) e diâmetro luminal, observados na magnitude de 100X. Selecionaram-se os campos com cortes histológicos no sentido transversal dos túbulos, desconsiderando-se aqueles em sentido longitudinal. Essas medições foram realizadas com auxílio do software tpsDig2 (ROHLF, 2006). Esse procedimento foi previamente descrito por Robertson et al. (1999) e Goyal et al. (2001). 
1.4.12 Dosagens séricas hormonais

\subsubsection{Testosterona}

O kit utilizado nesse experimento foi o de radioimunoensaio em fase sólida marcado com ${ }^{125}$ I designado para a dosagem quantitativa da testosterona total em soro sem extração da MPBiomedicals (Solon, OH, USA) (LAN et al., 2009). O hormônio marcado com ${ }^{125} \mathrm{I}$ compete por um período fixo de tempo com o hormônio da amostra para os sítios do anticorpo. O tubo é decantado, para separar a forma ligada da livre, e contado em um contador gama acoplado a um microcomputador. A quantidade de hormônio presente na amostra é determinada a partir de uma curva de calibração obtida pela dosagem dos calibradores que fazem parte do kit. A sensibilidade do teste foi de $0,008 \mathrm{ng} / \mathrm{mL}$. O coeficiente de variação intraensaio foi $<5 \%$. Os resultados foram expressos em $\eta \mathrm{g} / \mathrm{mL}$.

\subsubsection{Triiodotironina (T3)}

O T3 foi dosado através do kit comercial T3 Total Coat-A-Count (Siemens Medical Solutions Diagnostics, Los Angeles, CA, USA) por radioimunoensaio (técnica previamente descrita para a testosterona) (RASMUSSEN, 2003). Os resultados foram expressos em $\mathrm{ng} / \mathrm{mL}$, sendo o coeficiente de variação intraensaio $<4,7 \%$ e a sensibilidade mínima 0,41 $\eta \mathrm{g} / \mathrm{mL}$.

\subsubsection{LH e FSH}

O ensaio para a dosagem sérica de FSH e LH foi realizado através do kit comercial Lincoplex, Millipore, USA no Laboratório de Dosagens Hormonais da Genese Produtos Diagnósticos Ltda. Esse ensaio utiliza a tecnologia Luminex Corporation's хMAРтм (MAP=Multiple Analyte Profiling, $\mathrm{x}=$ analitos) que envolve um processo que cora internamente microesferas de poliestireno com dois fluorocromos espectrais distintos. Cada esfera é conjugada a um anticorpo analito específico. Estas microesferas são então combinadas em um único poço de reação e podem dosar até 100 analitos simultaneamente. A próxima etapa é a adição do anticorpo de detecção biotinilado.

Cada conjunto de microesferas está acoplado com anticorpo de captura específico. O anticorpo de captura, por sua vez, liga-se ao analito específico e então o anticorpo de detecção 
biotinilado se liga ao analito específico. O resultado final é amplificado através de incubação com o conjugado estreptavidina-ficoeritrina (AS-PE reporter), que emite sinal fluorescente. As microesferas são lidas no equipamento Luminex 100 através de sistema duplo de lasers que incide sob as microesferas, à medida que estas fluem através do fluxo celular. Um feixe de laser detecta a microesfera (o código de cor específico para o ensaio) e o outro laser quantifica o sinal de reporter em cada microesfera. As microesferas passam através do fluxo celular Luminex; cada microesfera é identificada, e o sinal SA-PE associado a elas é quantificado.

Os resultados foram expressos em $\mathrm{pg} / \mathrm{mL}$ para ambos os hormônios, sendo a sensibilidade para o LH de 2,91 pg/mL e para o FSH de $31 \mathrm{pg} / \mathrm{mL}$. O coeficiente de variação intraensaio foi $<2,5 \%$ para o $\mathrm{LH} \mathrm{e}<4,7 \%$ para o FSH.

\subsubsection{TSH}

O TSH sérico foi analisado por radioimunoensaio específico utilizando-se TSH de rato para iodação e preparação de curva padrão. O anticorpo primário foi obtido do National Hormone and Peptide Program/NIDDK (Bethesda, MD, USA). A sensibilidade foi de 0,18 $\mathrm{ng} / \mathrm{mL}$ e o coeficiente intraensaio foi $<4.3 \%$. Esse ensaio foi realizado no laboratório da Prof. ${ }^{a}$ Dr. ${ }^{\text {a }}$ Carmen Cabanelas Pazos de Moura, docente na UFRJ.

\subsubsection{Análise estatística}

Os resultados foram inicialmente avaliados quanto a sua distribuição pelo teste de Kolmogorov-Smirnov e quanto à homogeneidade de variâncias pelo teste de Bartlett. As variáveis que se comportaram de forma não-paramétrica foram transformadas em seu logaritmo natural correspondente, tendo retornado à sua característica paramétrica por definição. As comparações entre controle e TX foram realizadas pelo método teste t-Student, ao passo que as comparações entre mais de dois grupos foram realizadas pela análise de variâncias (ANOVA). A comparação entre a variável vesícula seminal e vesícula seminal drenada foi realizada pelos procedimentos teste t-Student para medidas repetidas e pela ANOVA para medidas repetidas. Quando a ANOVA apontou diferenças entre grupos, optouse pelo pós-teste de Tukey HSD (Honest Significant Diference) para tamanhos amostrais diferentes (SPJOTVOLL e STOLINE, 1973) ou iguais, conforme o caso. Considerou-se diferença estatística quando $\mathrm{p}<0,05$. Os dados estão expressos em média e erro padrão da 


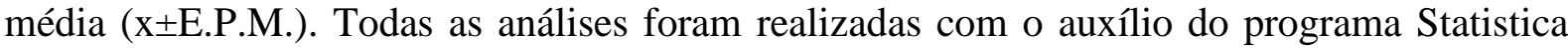
7.0, Statsoft. Utilizaram-se o total de 376 ratos, e cada procedimento ou parâmetro avaliado foi resultante de três experimentos distintos. 
Capítulo 2

\section{EFETIVIDADE DO TRATAMENTO}




\section{$2.1 \quad$ RESULTADOS}

A efetividade do tratamento foi comprovada pelas alterações no TSH e T3 séricos e no peso ventricular cardíaco dos animais em estudo. Os animais com hipotireoidismo (TX) apresentaram menor peso muscular cardíaco, tanto úmido quanto desidratado, em relação ao peso corporal, quando comparados aos animais controle e também o TSH sérico elevado. Os tratamentos agudos não alteraram esses parâmetros em relação aos animais hipotireoideos. Já para os animais com hipertireoidismo, tratados por cinco dias com triiodotironina (TXT3 $\left.3_{\text {crônico}}\right)$, o TSH apresentou-se reduzido e a massa muscular cardíaca aumentada, em relação ao peso corporal. O T3 total sérico apresentou-se reduzido no grupo TX, elevando-se nos grupos tratados com as diferentes doses de T3. Esses resultados estão registrados na tabela 2.1 .

Tabela 2.1 - Peso cardíaco úmido (PCU, mg/100 g PC), peso cardíaco desidratado (PCD, mg/100g $\mathrm{PC})$, concentração sérica de TSH $(\eta \mathrm{g} / \mathrm{mL})$ e de T3 total $(\eta \mathrm{g} / \mathrm{mL})$ nos ratos controle, TX e tratados com $\mathrm{T}_{3}$

\begin{tabular}{|c|c|c|c|c|}
\hline Grupos & $\begin{array}{c}\text { PCU (mg/100 g } \\
\text { PC) }\end{array}$ & PCD (mg/100 g PC) & 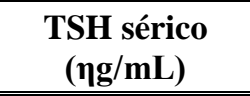 & $T 3$ total sérico $(\eta g / m L)$ \\
\hline Controle & $305,1 \pm 10,1^{\mathrm{a}}$ & $88,9 \pm 6,4^{c}$ & $1,47 \pm 0,25^{\mathrm{a}, \mathrm{c}}$ & $0,54 \pm 0,06^{\mathrm{a}, \mathrm{c}}$ \\
\hline $\mathrm{TX}$ & $272,6 \pm 28,1^{b}$ & $70,5 \pm 2,8^{\mathrm{d}}$ & $22,86 \pm 1,46^{\mathrm{d}}$ & $0,20 \pm 0,06^{\mathrm{b}, \mathrm{c}}$ \\
\hline $\mathrm{TXT}_{0,3}$ & $272,5 \pm 28,5^{b}$ & $72,4 \pm 32,8^{d}$ & $17,87 \pm 2,33^{\mathrm{d}}$ & $6,02 \pm 0,30^{\mathrm{d}}$ \\
\hline $\mathrm{TXT}_{1,5}$ & $277,1 \pm 8,3^{\mathrm{b}}$ & $72,7 \pm 5,6^{\mathrm{d}}$ & $20,91 \pm 2,11^{\mathrm{d}}$ & $9,24 \pm 0,09^{d}$ \\
\hline $\mathrm{TXT}_{15}$ & $249,9 \pm 5,8^{b}$ & $66,1 \pm 2,1^{\mathrm{d}}$ & $20,11 \pm 2,95^{\mathrm{d}}$ & $10,04 \pm 0,09^{d}$ \\
\hline TXT3 $3_{\text {rônico }}$ & $381,1 \pm 7,5^{\mathrm{b}}$ & $103,8 \pm 1,5^{\mathrm{d}}$ & $0,39 \pm 0,07^{\mathrm{b}}$ & $0,82 \pm 0,11^{\mathrm{a}, \mathrm{c}}$ \\
\hline
\end{tabular}




\subsection{DISCUSSÃO}

O modelo experimental utilizado neste estudo reproduz um quadro de hipotireoidismo primário por deficiência tireoideana, provocando elevados níveis de TSH circulantes e redução de $\mathrm{T}_{3}$ e $\mathrm{T}_{4}$. Assim, as dosagens séricas desses hormônios confirmam a adequação do modelo experimental.

As disfunções tireoideanas produzem alterações na contratilidade do coração, consumo de oxigênio, débito cardíaco, pressão arterial e resistência vascular sistêmica. $\mathrm{O} \mathrm{T}_{3}$ age no coração tanto através da interação com receptores clássicos quanto por mecanismos não genômicos, ativando a síntese de proteínas do tecido cardíaco, como a $\alpha$-MHC (cadeia pesada da miosina) (DANZI e KLEIN, 2005), a SERCa2 (Ca-ATPase do retículo sarcoplasmático) (GLOSS et al., 2005), receptor adrenérgico $\beta 1$, hormônio natriurético atrial, canais de potássio dependentes de voltagem, e ainda regulando negativamente a expressão da $\beta$-MHC, fosfolamban, subunidades catalíticas da adenilil ciclase, $\alpha 1-\mathrm{TR}$ (receptor tireoideano) e trocador $\mathrm{Na}^{+} / \mathrm{Ca}^{++}$(KLEIN e DANZI, 2007). O hipertireoidismo culmina numa hipertrofia cardíaca, enquanto o hipotireoidismo reduz a capacidade de contração do coração e diminui seu tamanho. As duas patologias produzem efeitos diametralmente opostos nas características descritas (KLEIN e DANZI, 2007; PORTMAN, 2008).

Em razão de o hipotireoidismo alterar o peso do coração, na proporção entre a sua musculatura e os líquidos intersticiais, torna-se ele um dos parâmetros utilizados para a verificação da efetividade do tratamento deste estudo. Conforme o esperado, os animais hipotireóideos (TX) apresentaram redução no peso cardíaco, tanto úmido quanto desidratado, assim como os animais tratados agudamente com $\mathrm{T}_{3}$. Já os animais tratados com a dose suprafisiológica de $5 \mathrm{X}$ por cinco dias $\left(\mathrm{TXT} 3_{\text {crônico }}\right)$ desenvolveram hipertireoidismo e apresentaram aumento no peso cardíaco.

Também é relevante a influência do grau de severidade do hipotireoidismo, a idade dos pacientes acometidos e o sexo sobre os parâmetros estudados (MEIKLE, 2004). No modelo experimental utilizado neste trabalho, os animais foram submetidos ao hipotireoidismo severo, pela remoção da glândula tireóide. Resta ainda salientar que o model utilizado é o masculino, uma vez que o sexo pode interferir com os parâmetros estudados, por ser crescente o interesse pela andrologia humana. 
Capítulo 3

\section{EFEITOS DO HIPOTIREOIDISMO SOBRE O EIXO HIPOTALÂMICO-HIPOFISÁRIO-GONADAL}


Este capítulo trata especificamente do hipotireoidismo, visando caracterizar o modelo experimental utilizado a partir dos parâmetros reprodutivos avaliados. O conteúdo é apresentado em três seções: delineamento experimental, resultados e discussão.

\subsection{DELINEAMENTO EXPERIMENTAL}

Para o estudo dos efeitos do hipotireoidismo sobre o eixo hipotalâmico hipofisário gonadal foi utilizado o delineamento da figura 3.1. Os animais foram tireoidectomizados cirurgicamente ou falso-operados e, após 21 dias de tratamento com metimazol ou água, os tecidos foram colhidos e submetidos às análises laboratoriais. O detalhamento dessa metodologia está descrito no capítulo 1.

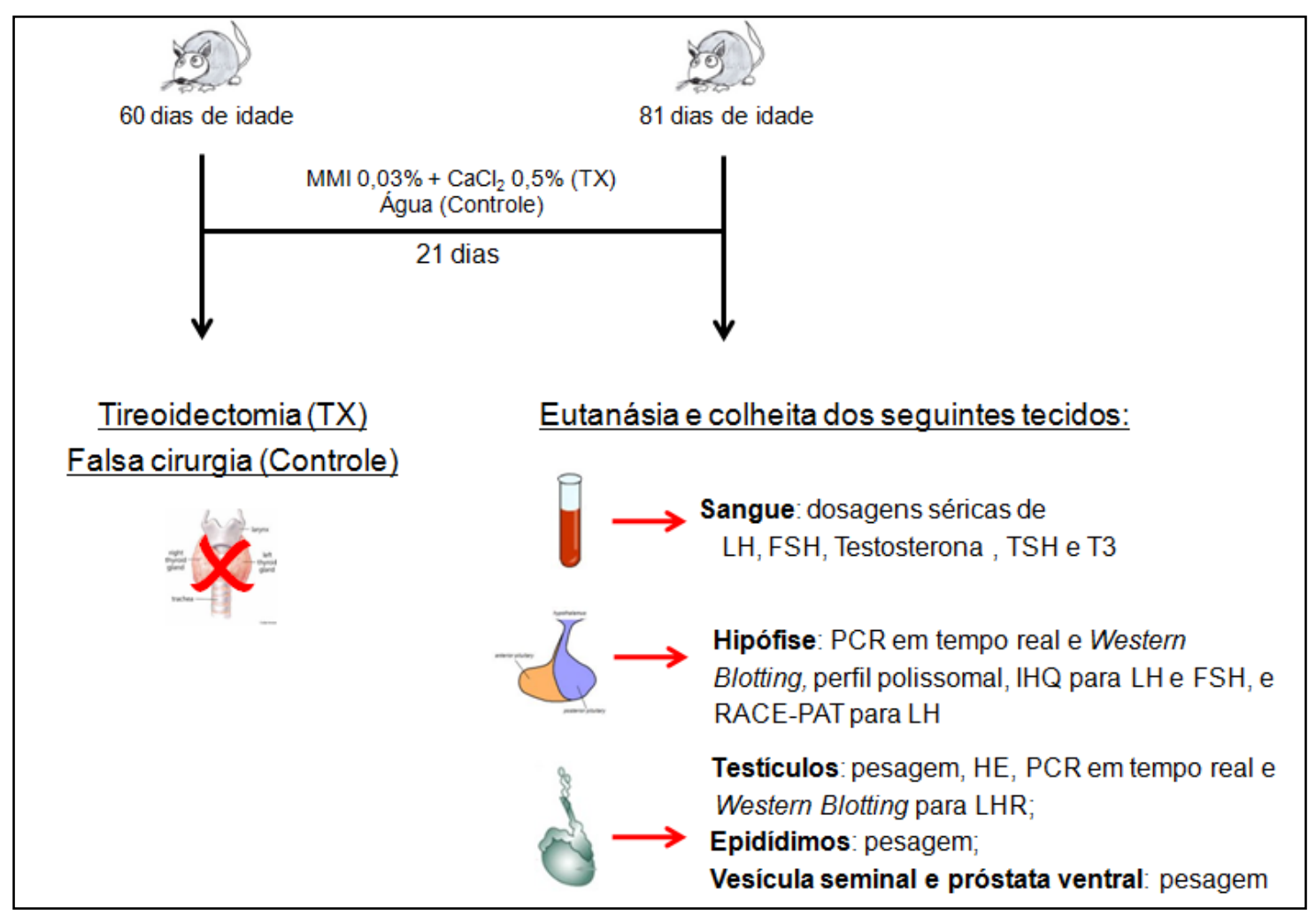

Figura 3.1 - Delineamento experimental utilizado para o estudo do hipotireoidismo. 


\subsection{RESULTADOS}

O hipotireoidismo causou várias alterações no eixo hipotalâmico hipofisário gonadal. Embora, desde o início, o objetivo principal deste trabalho tenha sido a investigação da glândula hipofisária, as alterações periféricas observadas macroscopicamente foram de tal evidência, que o seu estudo não pode ser negligenciado. Assim, alguns parâmetros para esses tecidos foram adicionados ao estudo principal. Os resultados estão divididos em duas seções principais: estudo hipofisário e tecidos periféricos.

O estudo hipofisário para o hipotireoidismo envolveu a análise da expressão gênica (mRNA e proteína), concentrações séricas e perfil polissomal para o ${ }_{\beta} \mathrm{LH}$ e ${ }_{\beta} \mathrm{FSH}$, análise da cauda poli(A) do mRNA do ${ }_{\beta} \mathrm{LH}$ e morfologia do gonadotrofo por imunohistoquímica para detecção de ${ }_{\beta} \mathrm{LH}$ e ${ }_{\beta} \mathrm{FSH}$.

O estudo dos tecidos periféricos envolveu a pesagem dos testículos, epidídimos, próstata ventral e vesícula seminal, dosagem da testosterona sérica, morfometria dos túbulos seminíferos e análise da expressão testicular (mRNA e proteína) de receptores de LH.

\subsubsection{Estudo do gonadotrofo}

\subsubsection{Expressão gênica e protéica e concentrações séricas de ${ }_{\beta} L H$ e ${ }_{\beta} F S H$}

O mRNA, a proteína hipofisária e a concentração sérica diferiram no hipotireoidismo tanto para $o_{\beta} \mathrm{FSH}$ quanto para $\mathrm{o}_{\beta} \mathrm{LH}$, quando comparados ao grupo controle. Com relação ao ${ }_{\beta} \mathrm{FSH}$, a expressão do mRNA mostrou-se elevada (Fig 3.2 A, p<0,05). Já o conteúdo protéico (Fig 3.2 B) e a concentração sérica (Fig 3.2 C) apresentaram-se reduzidos ( $p<0,05$ e p<0,01, respectivamente).

Com relação ao ${ }_{\beta} \mathrm{LH}$, a expressão do mRNA (Fig 3.3 A) e a concentração sérica (Fig $3.3 \mathrm{C}$ ) elevaram-se no hipotireoidismo ( $\mathrm{p}<0,05$ e $\mathrm{p}<0,01$, respectivamente), ao passo que o conteúdo protéico foi reduzido (Fig $3.3 \mathrm{~B}, \mathrm{p}<0,05)$.. 

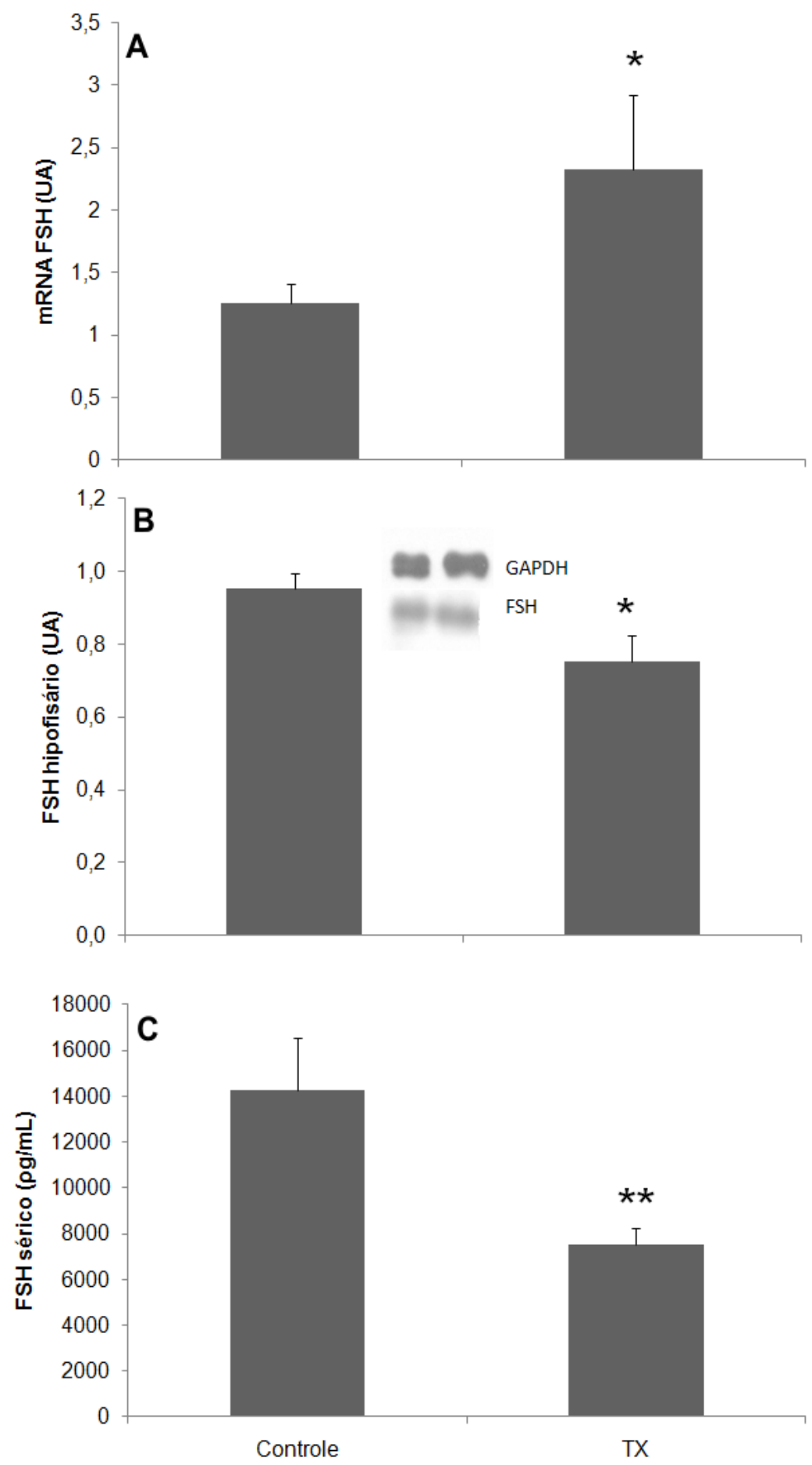

Figura 3.2 - Quantificações do mRNA (A), da proteína (B) e da concentração sérica (C) de ${ }_{\beta} \mathrm{FSH}$ em animais controle e hipotireoideos (TX). A expressão do mRNA apresentou-se elevada no TX, ao passo que o conteúdo protéico e o sérico apresentaram-se reduzidos. Os valores estão expressos em média \pm E.P.M. Teste $t$-Student, ${ }^{*} \mathrm{p}<0,05$ e $* * \mathrm{p}<0,01, \mathrm{n}=9$ a 11 animais/grupo/procedimento 

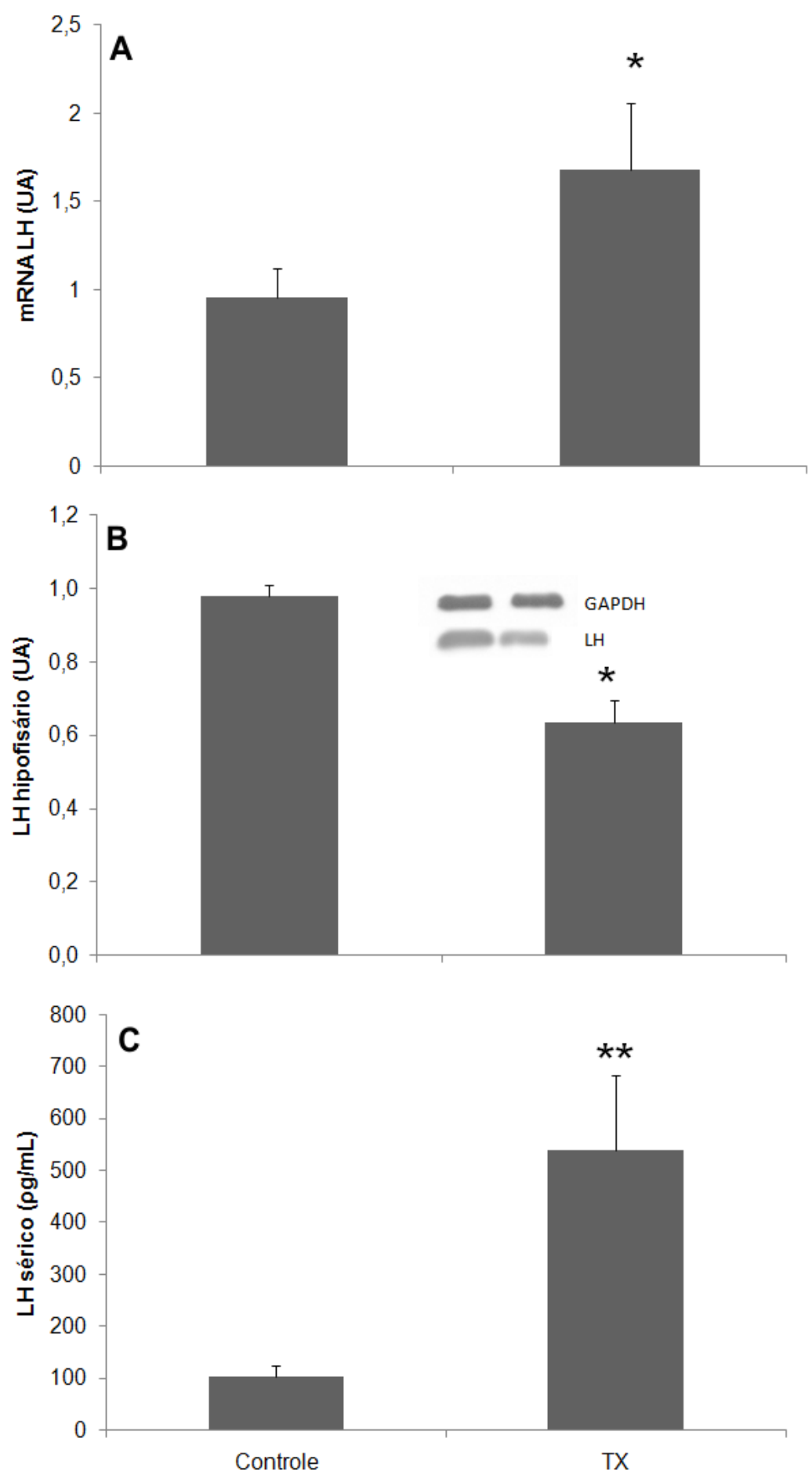

Figura 3.3 - Quantificações do mRNA (A), da proteína (B) e da concentração sérica (C) de LH em animais controle e hipotireoideos (TX). A expressão do mRNA e a concentração sérica apresentaram-se elevadas no TX, ao passo que o conteúdo protéico está reduzido. Os valores estão expressos em média \pm E.P.M. Teste $t$-Student, ${ }^{*} \mathrm{p}<0,05$ e ${ }^{* *} \mathrm{p}<0,01, \mathrm{n}=9$ a 11 animais/grupo/procedimento 
Com o objetivo de verificar se o tamanho da hipófise estaria alterando o resultado do Western Blotting, avaliou-se a recuperação protéica desse tecido nessas condições. As hipófises de animais hipotireoideos (TX) apresentaram maior peso do que as provenientes de animais controle. No entanto, a recuperação protéica não diferiu entre essas condições. Os dados estão expressos na Tabela 3.1.

Tabela 3.1 - Peso hipofisário e recuperação protéica hipofisária em ratos controle e hipotireóideos (TX)

\begin{tabular}{ccc}
\hline Grupos & $\begin{array}{c}\text { Peso hipofisário } \\
(\mathbf{m g} / 100 \text { g PC })\end{array}$ & $\begin{array}{c}\text { Recuperação protéica } \\
(\boldsymbol{\mu g} / \mathbf{m g} \text { tecido })\end{array}$ \\
\hline \hline Controle & $2,43 \pm 0,3^{\mathrm{a}}$ & $77,7 \pm 6,9$ \\
TX & $3,72 \pm 0,2^{\mathrm{b}}$ & $65,2 \pm 2,7$ \\
\hline
\end{tabular}

Os valores estão expressos em média \pm E.P.M.

Teste $t$-Student, a e b diferem entre si $\mathrm{p}<0,05, \mathrm{n}=9$ a 11 animais/grupo

\subsubsection{Perfil polissomal para o ${ }_{\beta} \mathrm{LH} e_{\beta} F S H$}

Neste estudo avaliou-se o conteúdo dos mRNAs de ${ }_{\beta} \mathrm{FSH}$ e ${ }_{\beta} \mathrm{LH}$ ancorados aos ribossomos, o que permite inferir o quanto de transcritos está sendo recrutado para a tradução naquele momento. Apesar de o perfil polissomal não apresentar nenhuma alteração entre os diferentes grupos experimentais, a quantidade de transcrito associado aos polissomos mostrou-se intensamente alterada. O hipotiroidismo provocou uma clara diminuição na quantidade de transcritos de beta-FSH e beta-LH ancorados aos polissomos; portanto, redução do recrutamento desses mRNAs à maquinaria traducional (Fig 3.4 e 3.5). 


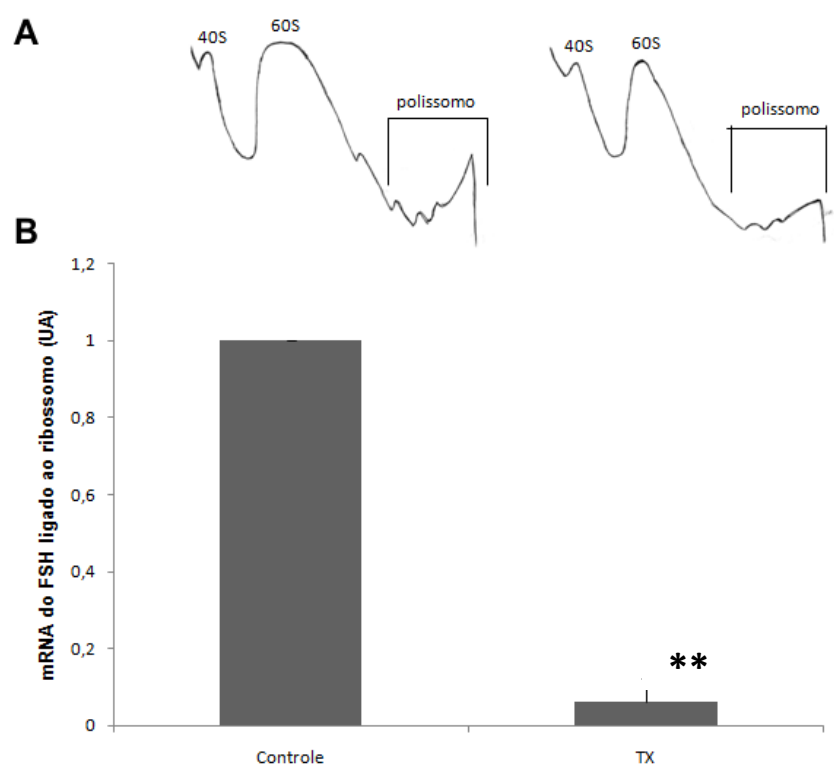

Figura 3.4 - O hipotireoidismo reduziu o conteúdo de mRNA do ${ }_{\beta} \mathrm{FSH}$ ligado ao ribossomo. Em (A) e (B) observa-se o perfil polissomal de mRNA do ${ }_{\beta} \mathrm{FSH}$ avaliado por PCR em tempo real. As subunidades ribossomais estão indicadas no perfil polissomal nos picos $40 \mathrm{~S}$ e $60 \mathrm{~S}$, seguidos pelo pico 80S monossomal e polissomal. Os valores estão expressos em média \pm E.P.M. Teste $t$-Student, $* * \mathrm{p}<0,01, \mathrm{~N}=3$ (x 10 hipófises/grupo)

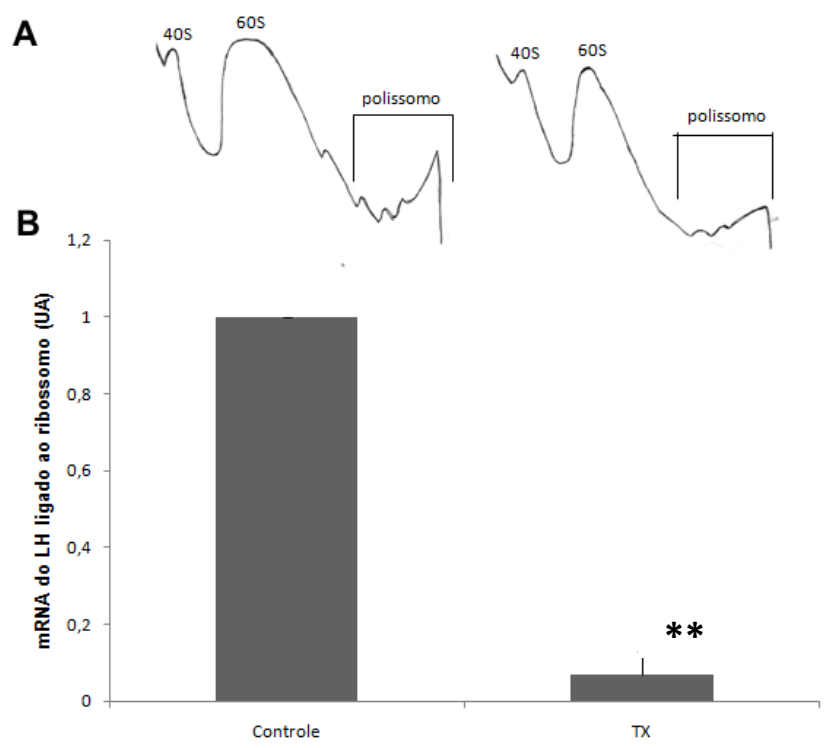

Figura 3.5 - O hipotireoidismo reduziu o conteúdo de mRNA do ${ }_{\beta} \mathrm{LH}$ ligado ao ribossomo. Em (A) e (B) observa-se o perfil polissomal de mRNA do ${ }_{\beta} \mathrm{LH}$ avaliado por PCR em tempo real. As subunidades ribossomais estão indicadas no perfil polissomal nos picos $40 \mathrm{~S}$ e $60 \mathrm{~S}$, seguidos pelo pico $80 \mathrm{~S}$ monossomal e polissomal. Os valores estão expressos em média \pm E.P.M. Teste $t$-Student, ${ }^{* *} \mathrm{p}<0,01, \mathrm{~N}=3$ (x 10 hipófises/grupo) 


\subsubsection{Análise da cauda do mRNA do ${ }_{\beta} L H$}

A análise do comprimento da cauda poli(A) do mRNA do ${ }_{\beta} \mathrm{LH}$ realizada pelo método de RACE-PAT mostrou que no hipotireoidismo houve redução do seu comprimento em relação ao controle $(\mathrm{p}<0,05)$. A figura 3.6 do lado esquerdo mostra o padrão de smear dos produtos de PCR em gel de agarose a 2,5\% corado com brometo de etídeo, e o lado direito da figura representa o comprimento da cauda poli(A) nos dois grupos experimentais. O tamanho mínimo do amplicon esperado foi de 128 pares de bases, que é relativo ao tamanho do fragmento de mRNA amplificado a partir da posição 389 da sua sequência gênica, até o sítio de poliadenilação. A cauda poli(A), portanto, corresponde ao comprimento total do fragmento gerado na amplificação do mRNA da amostra, subtraindo-se 128 pb.

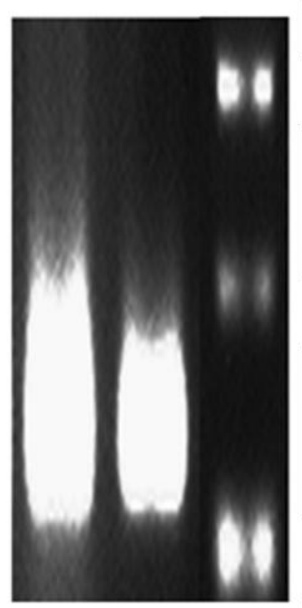

(A) (B)

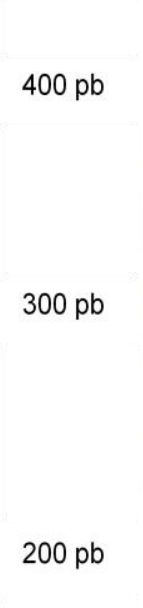

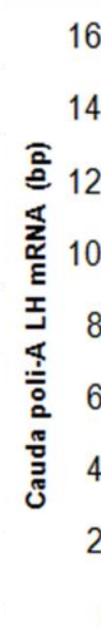

Figura 3.6 - Análise do comprimento da cauda poli(A) do mRNA do ${ }_{\beta} \mathrm{LH}$ pelo método de RACEPAT. Observa-se que há significativa redução no seu comprimento nos animais do grupo TX. Os valores estão expressos em média \pm E.P.M. Teste $t$-Student, $* \mathrm{p}<0,05$, $\mathrm{n}=8 / 9$ animais/grupo

\subsubsection{Imunohistoquímica do gonadotrofo}

Na imunohistoquímica das hipófises visualiza-se em azul o núcleo das células; em verde, os gonadotrofos marcados para ${ }_{\beta} \mathrm{LH}$ ou para ${ }_{\beta} \mathrm{FSH}$; em vermelho, o citoesqueleto de actina (a intensidade do vermelho corresponde ao seu grau de polimerização). 
Na marcação para ${ }_{\beta} \mathrm{LH}$ (Figura 3.7) observam-se alguns gonadotrofos distribuídos pelo campo, localizados ao redor de vasos sanguíneos (VS). Há acúmulo de grânulos na região perivascular (seta, A), associados com a polimerização de actina (B, C). No hipotireoidismo (TX) os gonadotrofos tiveram seu tamanho reduzido (D), estando a actina desorganizada (E) e com menor associação aos gonadotrofos (F).

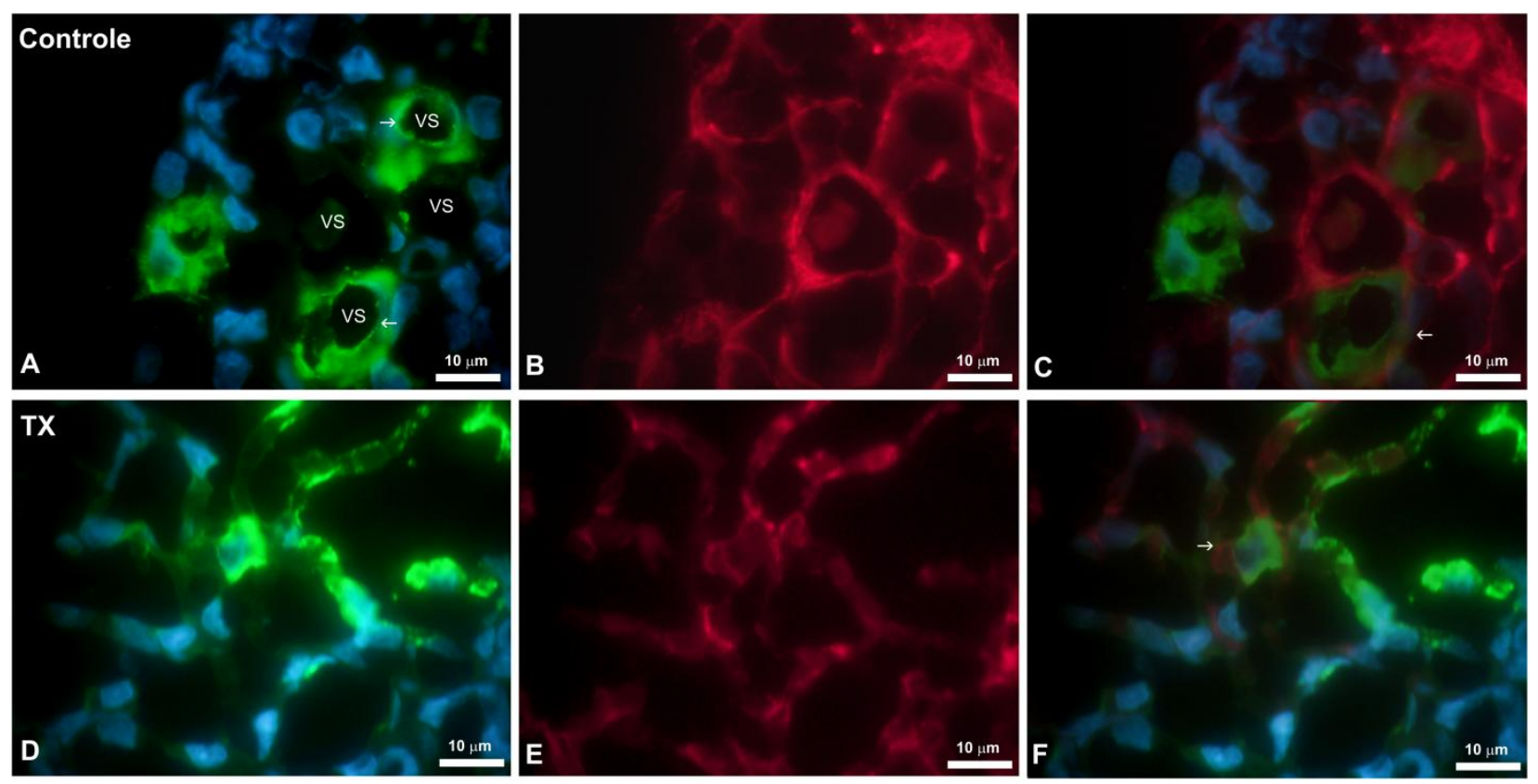

Figura 3.7 - Imunohistoquímica da hipófise para detecção de gonadotrofos em animais controle e hipotireoideos (TX) marcados para ${ }_{\beta}$ LH. Observa-se em azul o núcleo das células; em verde, os gonadotrofos marcados para ${ }_{\beta} \mathrm{LH}$; em vermelho, o citoesqueleto de actina polimerizado. $n=5 / 6$ animais por grupo. Magnitude 100X. Barra de escala: $10 \mu \mathrm{m}$

A figura 3.8 refere-se ao ${ }_{\beta} \mathrm{FSH}$. No grupo controle há grande quantidade de grânulos de ${ }_{\beta} \mathrm{FSH}$ distribuídos pelo citoplasma (A), o citoesqueleto de actina está organizado (B) e há associação de áreas granulares de hormônio e actina polimerizada (C). No grupo TX há intensa redução na marcação (D), desorganização do citoesqueleto de actina (E) e pouca associação da actina polimerizada aos grânulos de secreção (F). 


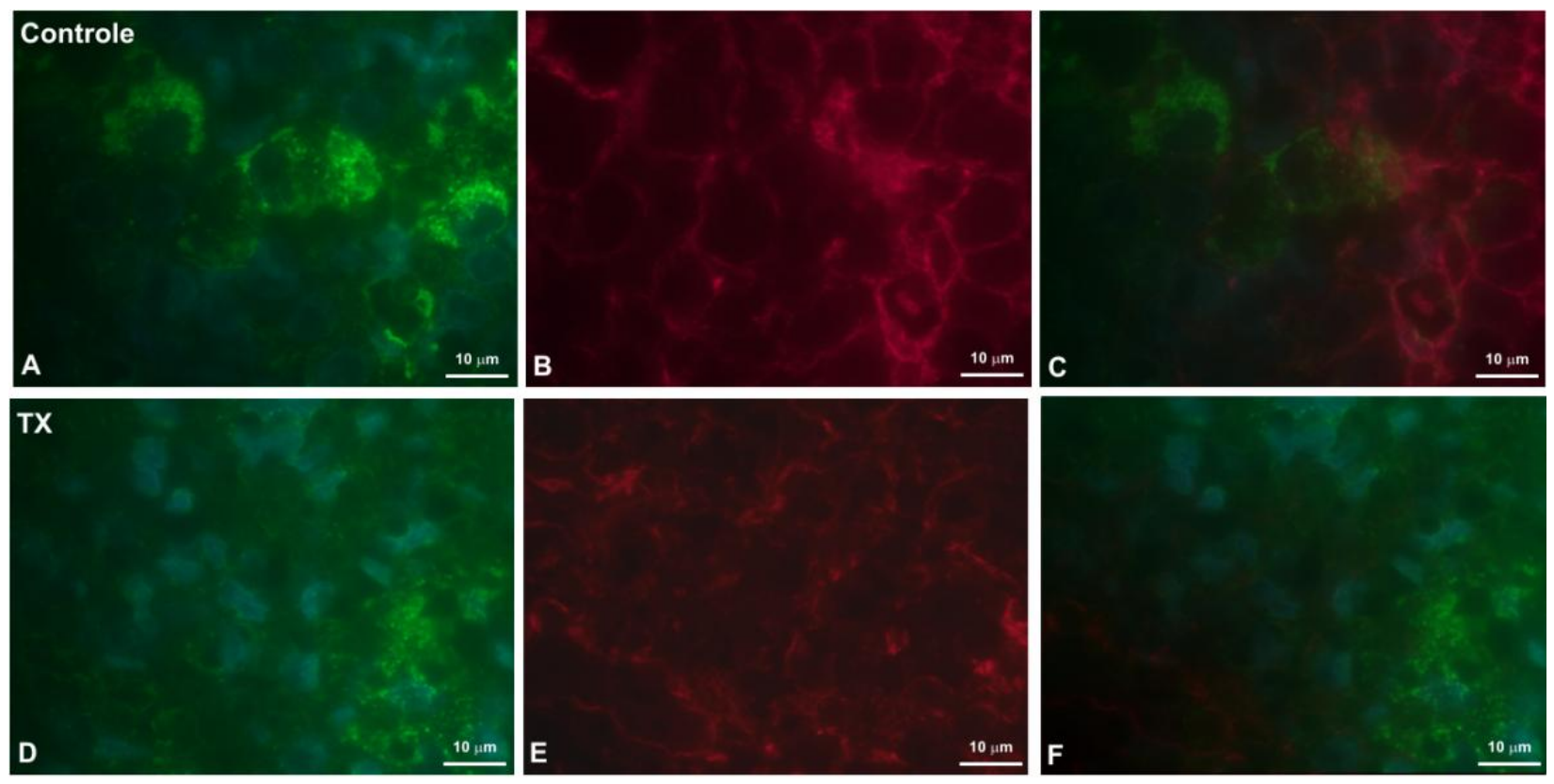

Figura 3.8 - Imunohistoquímica da hipófise para detecção de gonadotrofos em animais controle e hipotireoideos (TX) marcados para ${ }_{\beta} \mathrm{FSH}$. Observa-se em azul o núcleo das células; em verde, os gonadotrofos marcados para FSH; em vermelho, o citoesqueleto de actina polimerizado. $n=5 / 6$ animais por grupo. Magnitude 100X. Barra de escala: $10 \mu \mathrm{m}$

A figura 3.9 corresponde ao ensaio de IHQ sem a utilização do anticorpo primário, cujo objetivo é a verificação da especificidade do anticorpo utilizado. Assim, visualizam-se somente os núcleos das células marcados em azul pelo DAPI.

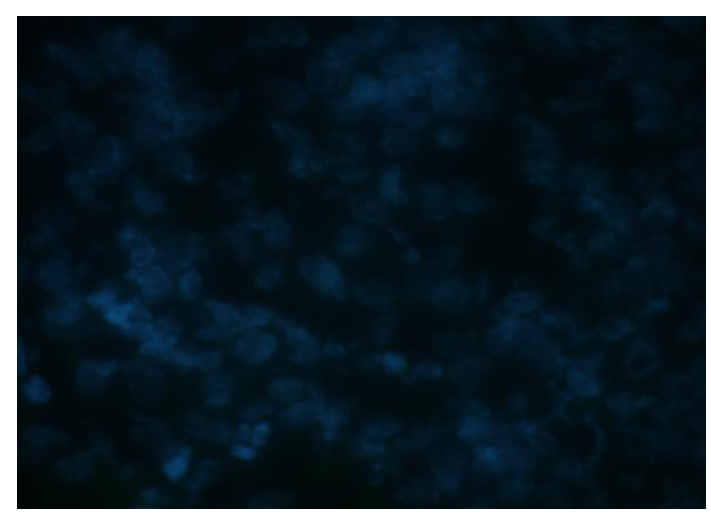

Figura 3.9 - Imunohistoquímica da hipófise para confirmação da especificidade do anticorpo (controle negativo). Observa-se em azul o núcleo das células. $\mathrm{n}=5 / 6$ animais por grupo. Magnitude 100X. Barra de escala: $10 \mu \mathrm{m}$ 


\subsubsection{Repercussões nos órgãos reprodutivos}

\subsubsection{Peso dos testículos, epidídimos, vesícula seminal e próstata ventral}

O efeito do HT sobre os órgãos reprodutivos foi avaliado pelos pesos relativos dos testículos, epidídimos, vesicular seminal e próstata ventral. Os pesos dos testículos $(p>0,05)$ e dos epidídimos $(\mathrm{p}=0,1)$ não se alteraram no hipotireoidismo. Já a vesícula seminal, além de muito menor $(\mathrm{p}<0,05)$, conteve menor quantidade de fluido seminal. A próstata ventral também apresentou redução de peso nos animais com hipotireoidismo $(\mathrm{p}<0,001)$. Os resultados estão apresentados nas Figuras 3.10 e 3.11.

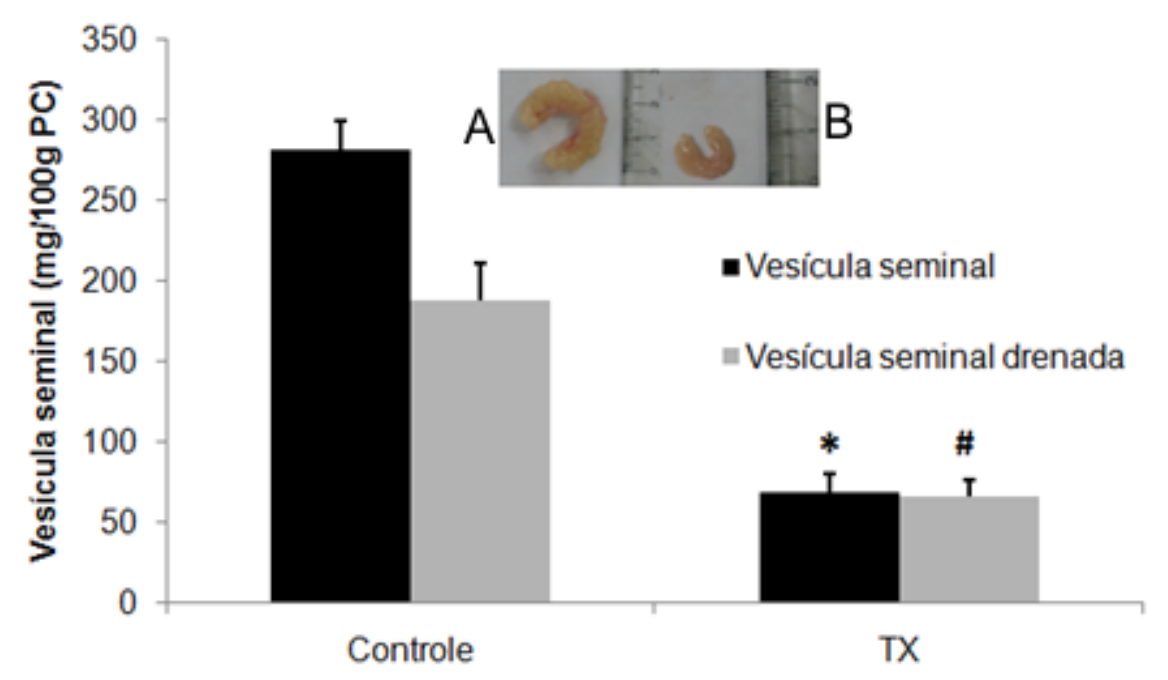

Figura 3.10 - Peso da vesícula seminal drenada e não drenada (mg/100g PC) nos ratos controle (A) e com hipotireoidismo (TX, B). Os valores estão expressos em média \pm E.P.M. Teste $t$ Student pareado, $\mathrm{n}=8 / 9$ animais/grupo * $p<0,05$ vesícula seminal controle e \# $p<0,01$ vesícula seminal drenada controle 

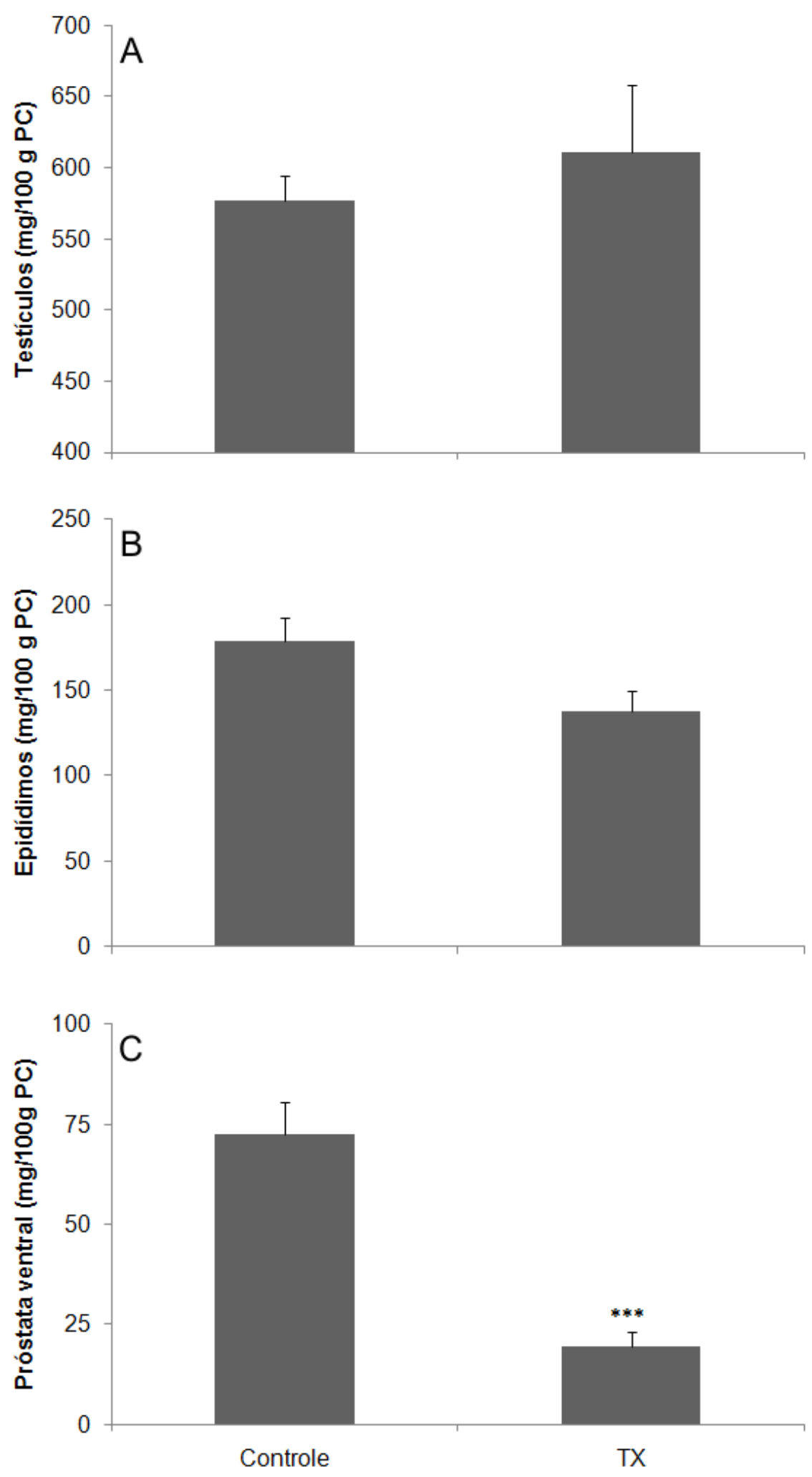

Figura 3.11 - Peso dos testículos (A), epidídimos (B) e próstata ventral (C) em mg/100 g PC nos ratos controle e com hipotireoidismo (TX). Os valores estão expressos em média \pm E.P.M. Teste $t$-Student, $* * * \mathrm{p}<0,001, \mathrm{n}=8 / 9$ animais/grupo 


\subsubsection{Dosagem sérica de testosterona}

Para verificar se o efeito do hipotireoidismo sobre o peso dos órgãos reprodutivos estava sendo mediado por alterações androgênicas, realizou-se a dosagem sérica de testosterona nos animais em estudo. A testosterona é produzida pelas células intersticiais testiculares de Leydig, sob estímulo do LH; de fato, sua concentração reduziu-se no hipotireoidismo $(\mathrm{p}<0,01)$, como registrado na figura 3.12 .

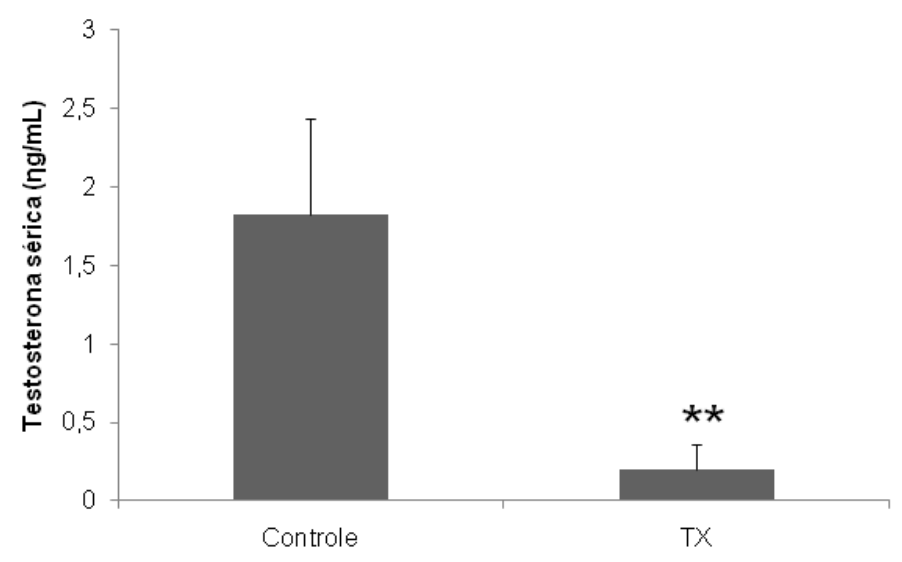

Figura 3.12 - Testosterona sérica em animais controle e hipotireóideos (TX). Os valores representam média \pm E.P.M., em ng/mL. Teste $t$-Student, $\mathrm{n}=8 / 9$ animais/grupo. ${ }^{*} * \mathrm{p}<0,01$

\subsubsection{Morfometria dos túbulos seminíferos}

Os testículos foram avaliados histologicamente quanto à morfometria linear dos túbulos seminíferos. Houve redução na espessura do epitélio germinativo $(p<0,01)$ e aumento no diâmetro luminal dos animais hipotireoideos $(\mathrm{p}<0,05)$. Já o diâmetro tubular total permaneceu inalterado. A descrição desses resultados está apresentada na tabela 3.2 e indicada na figura 3.13 . 
Tabela 3.2 - Morfometria linear dos túbulos seminíferos em ratos controle e tireoidectomizados.

\begin{tabular}{ccc}
\hline Parâmetro & Controle & TX \\
\hline \hline Diâmetro tubular $(\mu \mathrm{m})$ & $232,7 \pm 5,1$ & $217,9 \pm 5,6$ \\
Espessura epitelial $(\mu \mathrm{m})$ & $128,2 \pm 3,3^{\mathrm{c}}$ & $97,5 \pm 5,5^{\mathrm{d}}$ \\
Diâmetro luminal $(\mu \mathrm{m})$ & $104,3 \pm 4,0^{\mathrm{a}}$ & $120,4 \pm 2,7^{\mathrm{b}}$ \\
\hline
\end{tabular}

Os valores estão expressos em média \pm E.P.M.

Teste $t$-Student, a e b diferem entre si $\mathrm{p}<0,05$ e $\mathrm{c}$ e $\mathrm{d}<0,01, \mathrm{n}=4$ animais/grupo

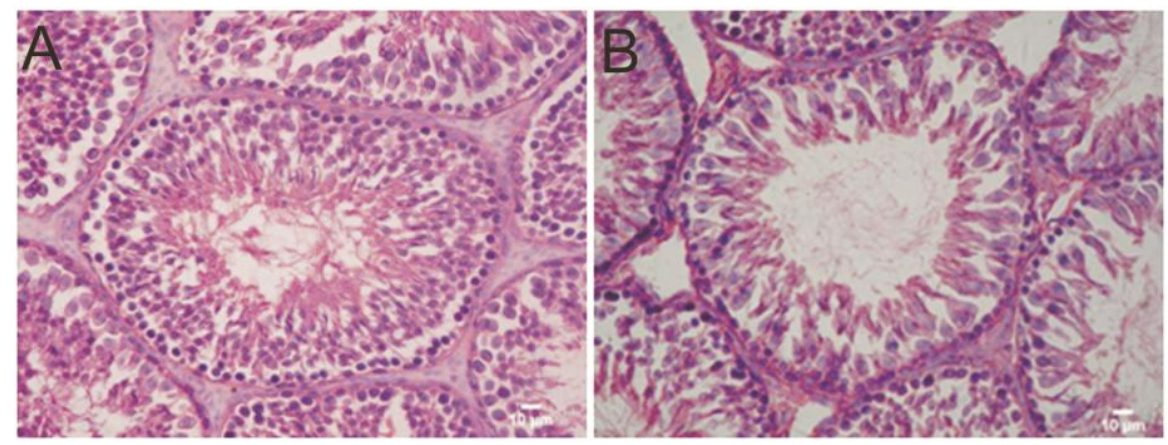

Figura 3.13 - Corte histológico de testículo de animal do grupo controle (A) e hipotireoideo (TX). Observam-se grande quantidade de células germinativas no epitélio e espermatozóides na luz tubular para o grupo controle, ao passo que no hipotireoidismo é evidente menor quantidade de células germinativas no epitélio, que ainda apresenta menor espessura e poucos espermatozóides na luz tubular. HE. Magnitude 100X

\subsubsection{Expressão testicular de receptores de andrógenos e de LH}

Um importante parâmetro para a constatação da ação hormonal é a expressão dos seus receptores nos tecidos alvo. Assim, avaliou-se a expressão do receptor de LH. A expressão do seu mRNA foi maior no hipotireoidismo ( $\mathrm{p}<0,05$, Figura $3.14 \mathrm{~A}$ ), ao passo que a quantidade de proteína foi reduzida ( $<<0,05$, Figura 3.14 B). 

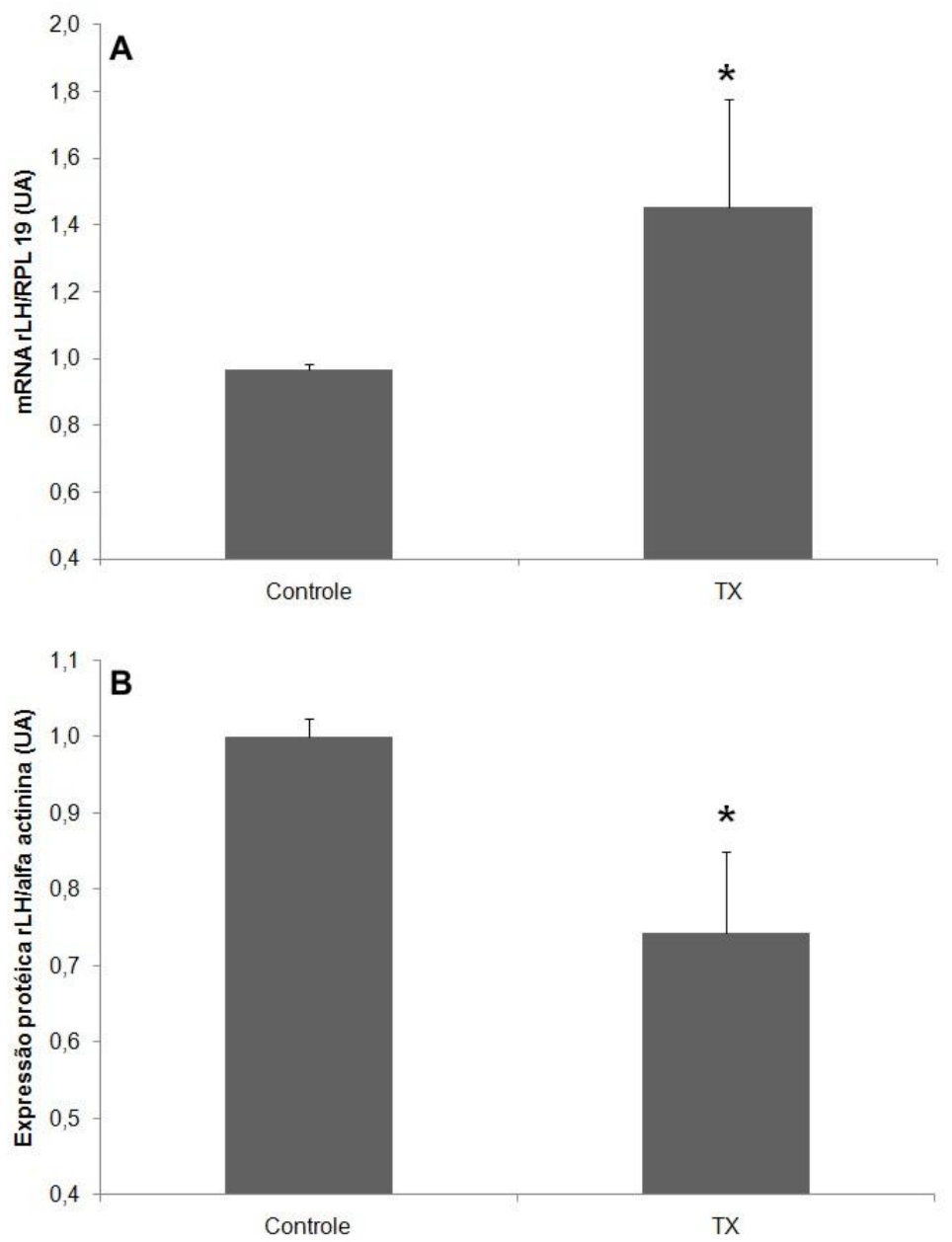

Alfa actinina $(100 \mathrm{Kda})$

] $\operatorname{rLH}(85 \mathrm{Kda})$

Figura 3.14 - Expressão testicular de receptores de LH em animais controle e TX. Em (A) observa-se o mRNA e em (B), o conteúdo protéico. Os valores representam média \pm E.P.M, Teste $t$-Student, ${ }^{*} \mathrm{p}<0,05, \mathrm{n}=10$ a 12 animais/grupo/procedimento 


\subsection{DISCUSSÃO}

3.3.1 O hipotireoidismo altera mecanismos moleculares da síntese e secreção de ${ }_{\beta} \mathrm{LH}$ e ${ }_{\beta} \mathrm{FSH}$

No hipotireoidismo primário prolongado, a hiperplasia dos tireotrofos pode resultar no aumento da hipófise e na expansão sobre a sela turcica, tanto em adultos quanto em crianças (JOSHI e WOOLF, 2005). Além desse efeito sobre os tireotrofos, o TRH estimula de forma significativa os lactotrofos, contribuindo para o aumento no tamanho da hipófise (FEKETE e LECHAN, 2007). Esse efeito sobre o tamanho hipofisário foi observado neste estudo nos ratos com hipotireoidismo. Apesar do tamanho aumentado, a recuperação protéica total foi equivalente entre os animais controle e hipotireoidismo, indicando que a proporção entre a produção de proteínas e o volume celular foi mantida.

Os efeitos do hipotireoidismo sobre a produção de gonadotrofinas são controversos na literatura. Toni et al. (2005) relatam que o hipotireoidismo em ratos pode tanto reduzir os níveis basais da secreção de LH e FSH, quanto estimulados por GnRH, bem como reduzir o tamanho e número de gonadotrofos, ou ainda não produzir nenhum efeito sobre a secreção ou número de células. Essa variabilidade de manifestações, como citado anteriormente (MEIKLE, 2004), poderia estar relacionada à severidade do hipotireoidismo.

No hipotireoidismo induzido nesse experimento foi observado aumento no conteúdo do mRNA dos hormônios ${ }_{\beta} \mathrm{LH} \mathrm{e}{ }_{\beta} \mathrm{FSH}$, embora não haja relatos de que a região promotora dos genes que codificam as subunidades $\beta$ específicas do LH ou FSH hipofisário, ou mesmo o GnRH hipotalâmico, apresentem TRE (MEIKLE, 2004; TONI et al., 2005). Entretanto, a expressão de receptores de HT em gonadotrofos é bastante representativa, maior até do que em tireotrofos e somatotrofos, o que indica a possibilidade de regulação da função dos gonadotrofos por esse hormônio, possivelmente por uma via indireta (ALKEMADE et al., 2006; FLIERS et al., 2006).

Apesar de o conteúdo do mRNA estar aumentada, o conteúdo de FSH hipofisário e a sua concentração sérica apresentaram-se diminuídos no hipotireoidismo. Tohei et al. (1997) também observaram redução no FSH hipofisário. Além disso, o gonadotrofo marcado para FSH mostrou menor quantidade de células reativas, bem como apontou, no perfil polissomal, menor associação do mRNA do FSH aos ribossomos, sugerindo que a sua taxa de tradução esteja reduzida, o que explica a menor concentração hipofisária e sérica desse hormônio (GOULART-SILVA et al., 2010). 
A diminuição da síntese de FSH pode estar relacionada com a ação parácrina de foliculostatina no gonadotrofo, como observado por Oride et al. (2009) em cultivo celular misto de LßT2 (linhagem murina imortalizada de gonadotrofo) e GH3 (linhagem celular que sintetiza e secreta prolactina e hormônio do crescimento). O hipotireoidismo induziu as células GH3 a sintetizarem foliculostatina, que inibiu a produção de FSH pelo gonadotrofo (LßT2).

Em paralelo ao aumento do mRNA do ${ }_{\beta} \mathrm{LH}$, houve redução do comprimento da sua cauda poli(A), o que sugere que o transcrito de LH esteja mais vulnerável à ação de nucleases e com comprometimento da sua tradução, já que esses processos estão diretamente relacionados com o tamanho dessa cauda (BAGALOPAL e PARKER, 2009; BUCHAN e PARKER, 2009). Além disso, a análise do perfil polissomal revelou uma menor associação do LH aos ribossomos, o que também relaciona a uma menor taxa de tradução (PROUD, 2007). De fato, foi detectada redução do conteúdo hipofisário de LH e do tamanho dos gonadotrofos, resultados esses também descritos por Tohei et al. (1997). Ao contrário do previsto por meio destes resultados, o LH sérico está aumentado, e isso poderia decorrer de alterações nos mecanismos envolvidos na manutenção desse hormônio na circulação, bem como de redução da concnetração da testosterona sérica, o que será detalhado no próximo ítem. Sabe-se que o hipotireoidismo provoca alterações renais como a diminuição da filtração glomerular, hiponatremia, diminuição da capacidade de diluição da urina, diminuição da reabsorção de sódio, diminuição do fluxo renal e elevação da creatinina sérica (IGLESIAS e DIEZ, 2009) e como a excreção do LH é renal, isso poderia resultar na elevação da sua concentração sérica (GAY, 1974; KRETSER et al., 1973).

3.3.2 Testosterona sérica reduzida: relação com o elevado LH circulante e repercussões nos tecidos andrógeno-dependentes

Apesar dos altos níveis circulantes de LH, o qual se pressupõe que se ligue ao seu receptor e estimule a produção de testosterona, houve uma intensa redução na testosterona sérica nos animais hipotireoideos, com reflexos diretos nos órgãos sexuais acessórios, verificado pelo baixo peso da vesícula seminal e da próstata ventral. Esses tecidos são dependentes da ação de testosterona e, na sua ausência, o seu funcionamento fica comprometido. Nas glândulas acessórias são produzidos fluidos que comporão o ejaculado. A próstata expressa grande quantidade de receptores androgênicos, sendo bastante sensível à redução das concentrações hormonais de testosterona e DHT. Na vesícula seminal são 
produzidas e secretadas frutose, prostaglandinas e enzimas que diminuem a produção das espécies reativas de oxigênio, deletérias aos espermatozóides (RISBRIDGER e TAYLOR, 2006). Assim, a baixa atividade observada dessas glândulas pode ajudar a explicar alterações espermáticas observadas no hipotireoidismo.

O peso testicular relativo não foi alterado pela falta de hormônio tireoideano, embora seja observado durante a fase pré-púbere que o hipotireoidismo leva ao hipergonadismo e à imaturidade celular em testículos de ratos (ARIYARATANE et al., 2000; CHAPIN et al., 1996). Contudo, no início do experimento os animais já se encontravam na idade adulta e o desenvolvimento testicular já havia se completado. Portanto, a ação do HT sobre o crescimento e diferenciação gonadal se desenrolou de forma normal desde a fase neonatal.

A célula de Sertoli produz os fatores que são fundamentais para o desenvolvimento normal da espermatogênese, na diferenciação da espermatogônia ao espermatozóide, apresentando receptores para FSH e testosterona, que são os principais reguladores da espermatogênese (SOFIKIS et al., 2008; WALKER e CHENG, 2005). Relata-se alteração na espermatogênese em animais que não expressam receptores de FSH e de andrógenos (O'SHAUGHNESSY et al., 2009) e também associada à concentração sérica inadequada de gonadotrofinas, com prejuízo na produção de testosterona (LENZI et al., 2009).

Assim, a redução da espessura epitelial dos túbulos seminíferos pode estar correlacionada ao menor FSH e testosterona séricos. A testosterona é responsável pela proliferação inicial da espermatogônia no epitélio seminífero ao se ligar ao receptor de andrógeno da célula de Sertoli. A sua transformação em estradiol, em pequenas quantidades, atua paracrinamente nas espermatogônias e espermatócitos em desenvolvimento, estimulando os eventos que proporcionam a sua diferenciação a espermatozóide (RISBRIDGER e TAYLOR, 2006). Logo, a redução na testosterona pode causar danos à arquitetura testicular (ROMANO et al., 2010).

Problemas na espermatogênese, devido ao hipotireoidismo, também foram observados em pacientes humanos, nos quais a diminuição do número de células germinativas, diminuição do número de espermatozóides vivos (SAHOO et al., 2008) e o aumento da patologia espermática foram detectados, sendo restabelecida após tratamento com o HT (KRASSAS et al., 2008).

Considerando-se que o receptor de LH media a atividade do LH, investigou-se se a sua expressão é afetada pelo hipotireoidismo. E, apesar de o mRNA do receptor de LH ter aumentado, houve uma redução significativa do seu conteúdo protéico, que pode auxiliar na explicação da baixa resposta ao elevado LH circulante. Esses dados sugerem que o HT regula 
a expressão do receptor de LH, possivelmente por um mecanismo pós transcricional. Ressalte-se que a exposição de células testiculares a altas concentrações de LH ou hCG reduz tanto o mRNA quanto a proteína do receptor de LH (ASCOLI et al., 2002).

É curioso que algumas ações do HT sobre o crescimento, diferenciação e esteroidogênese das células de Leydig e de Sertoli supostamente ocorrem apenas antes da vida adulta (MARAN, 2003). Entretanto, algumas disfunções das células de Leydig ocasionadas pelo hipotireoidismo são reversíveis pela suplementação com HT na vida adulta (ANTONY et al., 2005; VALENTI et al., 1997), o que é altamente sugestivo que o HT aja no testículo adulto. Apesar dessas evidências, a atividade do HT nas gônadas é ainda controversa, pois pequenas quantidades de TR estão presentes nos testículos de animais adultos, que são classicamente considerados como não responsivos ao HT (JANNINI et al., 1990, 1995). 
Capítulo 4

RESPOSTA DO EIXO HIPOTALÂMICO-HIPOFISÁRIOGONADAL AO TRATAMENTO COM TRIIODOTIRONINA (T3) 
A fim de se avaliar o efeito do HT sobre o eixo hipotalâmico hipofisário gonadal, administrou-se triiodotironina (T3) aos animais com hipotireoidismo. As doses, períodos e tecidos colhidos estão demonstrados no delineamento experimental; seguem-se a eles os resultados e a discussão.

\subsection{DELINEAMENTO EXPERIMENTAL}

O estudo do efeito do T3 sobre o eixo hipotalâmico hipofisário gonadal foi realizado com a administração desse hormônio aos animais com hipotireoidismo. Três delineamentos foram utilizados: (1) administração de T3 nas doses de 0,3, 1,5 e $15 \mu \mathrm{g} / 100 \mathrm{~g}$ PC e eutanásia após 30 min (Fig. 4.1); (2) administração de T3 na dose de 1,5 $\mu \mathrm{g} / 100$ g PC por 5 dias (Fig 4.2); e (3) administração de T3 nas doses de 0,3, 1,5 e $15 \mu \mathrm{g} / 100 \mathrm{~g}$ PC e eutanásia após 1, 2 e 3 horas (Fig. 4.3). O detalhamento das metodologias pode ser encontrado no capítulo 1.

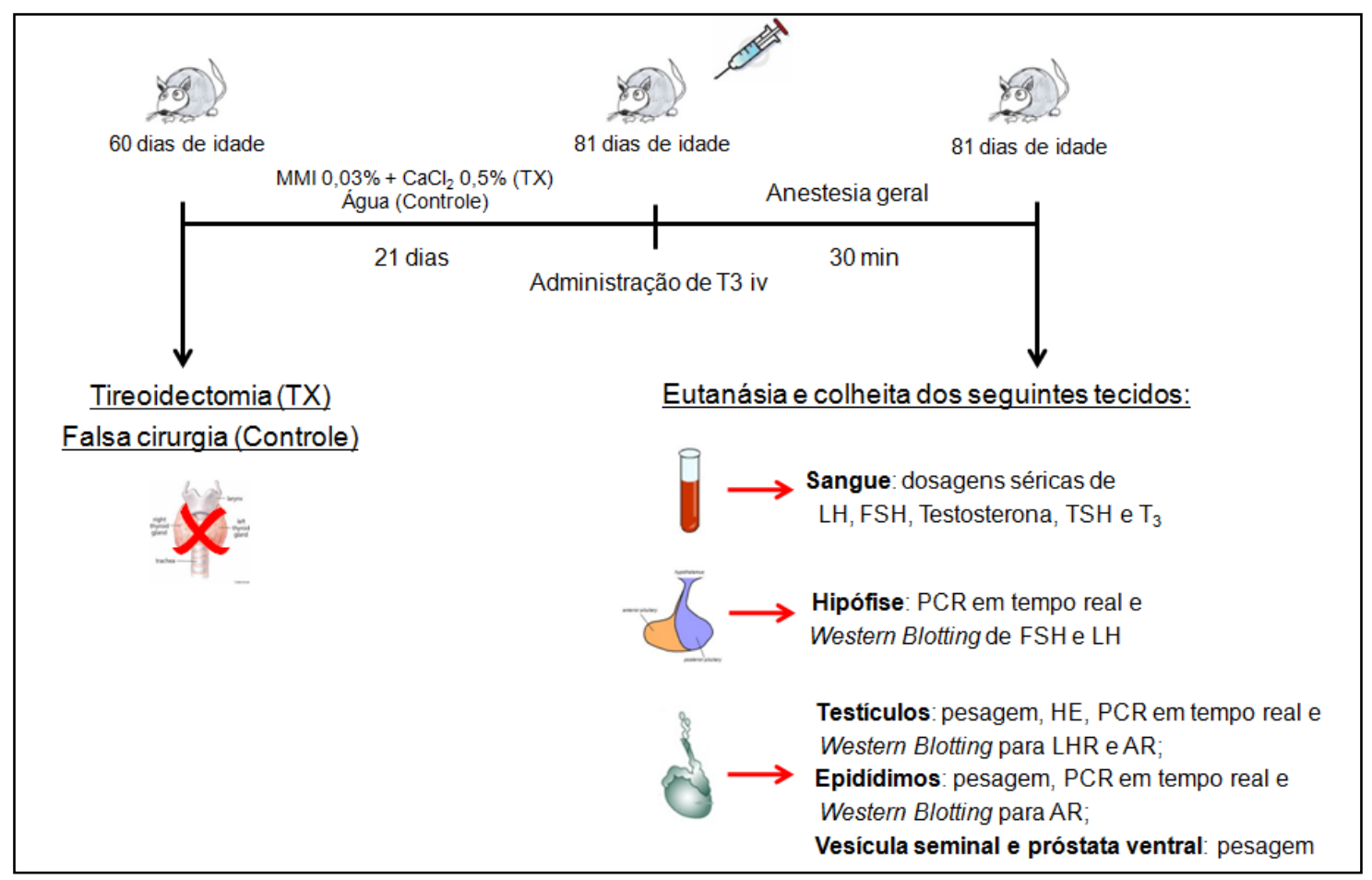

Figura 4.1 - Delineamento experimental para a avaliação do efeito do T3 após 30 min. 


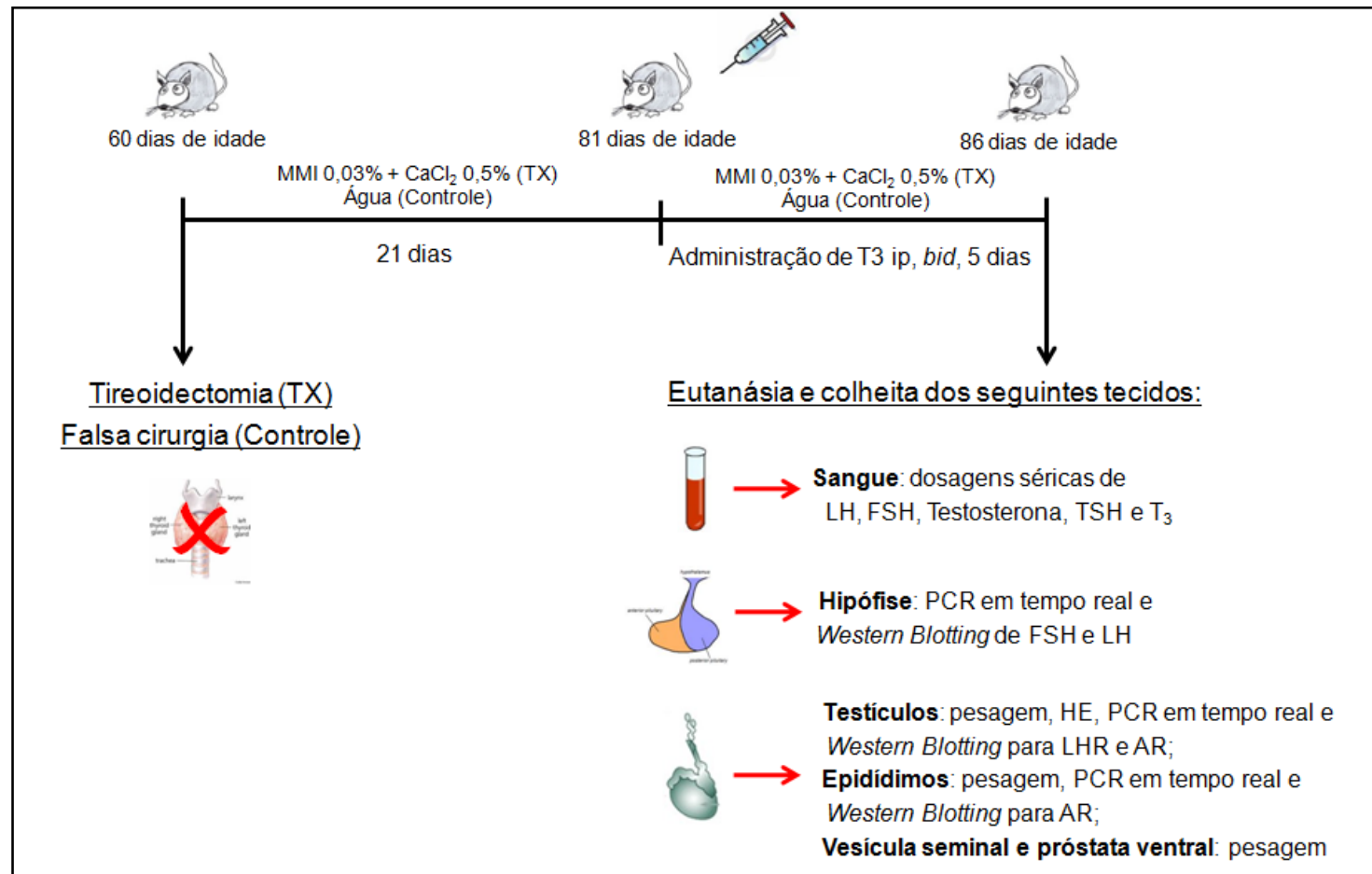

Figura 4.2 - Delineamento experimental para a avaliação do efeito do T3 após 5 dias de tratamento.

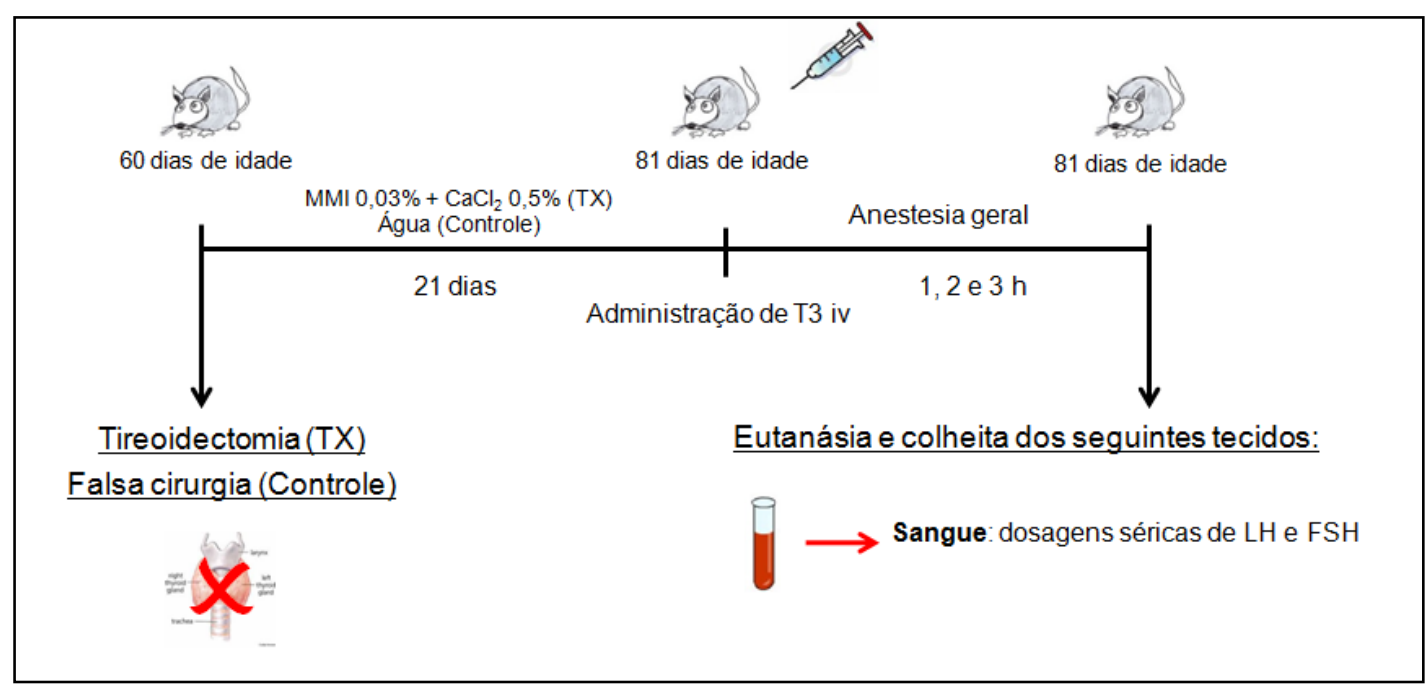

Figura 4.3 - Delineamento experimental para a avaliação do efeito do T3 após 1, 2 e 3 horas do tratamento. 


\subsection{RESULTADOS}

Os resultados estão divididos em duas seções principais, da mesma forma que a adotada no capítulo 3: estudo hipofisário e tecidos periféricos.

O estudo hipofisário para a avaliação dos efeitos do tratamento com T3 envolveu a análise da expressão gênica (mRNA e proteína), concentrações séricas e perfil polissomal para o ${ }_{\beta} \mathrm{LH}$ e ${ }_{\beta} \mathrm{FSH}$, análise do comprimento da cauda poli(A) do mRNA do ${ }_{\beta} \mathrm{LH}$ e morfologia do gonadotrofo por imunohistoquímica para detecção de ${ }_{\beta} \mathrm{LH} e_{\beta} \mathrm{FSH}$. Os resultados referentes ao LH são apresentados primeiramente; em seguida, apresentar-se-ão os resultados referentes ao FSH.

O estudo dos tecidos periféricos envolveu a pesagem dos testículos, epidídimos, próstata ventral e vesícula seminal, dosagem da testosterona sérica, análise da expressão testicular (mRNA e proteína) de receptores de andrógenos e receptores de LH e ainda expressão epididimal (mRNA e proteína) de receptores de andrógenos.

\subsubsection{Estudo do gonadotrofo}

\subsubsection{Peso hipofisário e recuperação protéica}

As hipófises de animais hipotireóideos (TX) e tratados com T3 são mais pesadas do que as provenientes de animais controle. No entanto, a recuperação protéica não diferiu entre essas condições (Tabela 4.1). Assim, o tamanho da hipófise não alterou o resultado do Western Blotting, 
Tabela 4.1 - Peso hipofisário (mg/100 g PC, x \pm EPM) e recuperação protéica hipofisária $(\mu \mathrm{g} / \mathrm{mg}$ tecido, $\mathrm{x} \pm \mathrm{EPM})$ em ratos controle, hipotireóideos e tratados com T3

\begin{tabular}{ccc}
\hline Grupos & $\begin{array}{c}\text { Peso hipofisário } \\
(\mathbf{m g} / \mathbf{1 0 0} \mathbf{g} \text { PC })\end{array}$ & $\begin{array}{c}\text { Recuperação protéica } \\
(\boldsymbol{\mu g} / \mathbf{m g} \text { tecido) }\end{array}$ \\
\hline \hline Controle & $2,43 \pm 0,3^{\mathrm{a}}$ & $77,7 \pm 6,9$ \\
TX & $3,72 \pm 0,17^{\mathrm{b}}$ & $65,2 \pm 2,7$ \\
TXT3-0,3 & $3,18 \pm 0,18^{\mathrm{b}}$ & $65,4 \pm 2,3$ \\
TXT3-1,5 & $3,57 \pm 0,16^{\mathrm{b}}$ & $69,7 \pm 4,3$ \\
TXT3-15 & $3,27 \pm 0,37^{\mathrm{b}}$ & $57,8 \pm 2,8$ \\
TXT3 crônico & $3,18 \pm 0,14^{\mathrm{b}}$ & $61,2 \pm 11,6$ \\
\hline \multicolumn{2}{c}{ Teste ANOVA e pós-teste de Tukey; a e b diferem entre si $\mathrm{p}<0,05, \mathrm{n}=9$ a 11 animais/grupo }
\end{tabular}

4.2.1.2 Hormônio luteinizante: expressão, produção e secreção

\subsection{Expressão gênica e protéica e concentrações séricas}

A análise da expressão gênica do ${ }_{\beta} \mathrm{LH}$ por meio da quantificação do seu mRNA demonstrou que os tratamentos agudos com T3 diminuíram seus conteúdos $(p<0,01)$ tanto em relação ao grupo controle quanto em relação ao grupo TX. Já o tratamento crônico com T3 reduziu o conteúdo do mRNA do ${ }_{\beta} \mathrm{LH}$ aos observados no grupo controle $(\mathrm{p}<0,05$ vs TX) (Figura $4.4 \mathrm{~A}$ ).

O conteúdo hipofisário protéico de ${ }_{\beta} \mathrm{LH}$ foi restabelecido nos tratamentos agudos e no crônico, igualando-se estatisticamente ao observado no grupo controle (Figura 4.4 B).

O tratamento agudo com T3 não alterou a concentração sérica de $\mathrm{LH}$, mantendo a elevação observada no grupo TX $(\mathrm{p}<0,01)$. $\mathrm{O}$ tratamento crônico promoveu a sua redução tanto em relação ao TX e tratamentos agudos quanto em relação ao controle $(p<0,05)$ (Figura $4.4 \mathrm{C})$. 

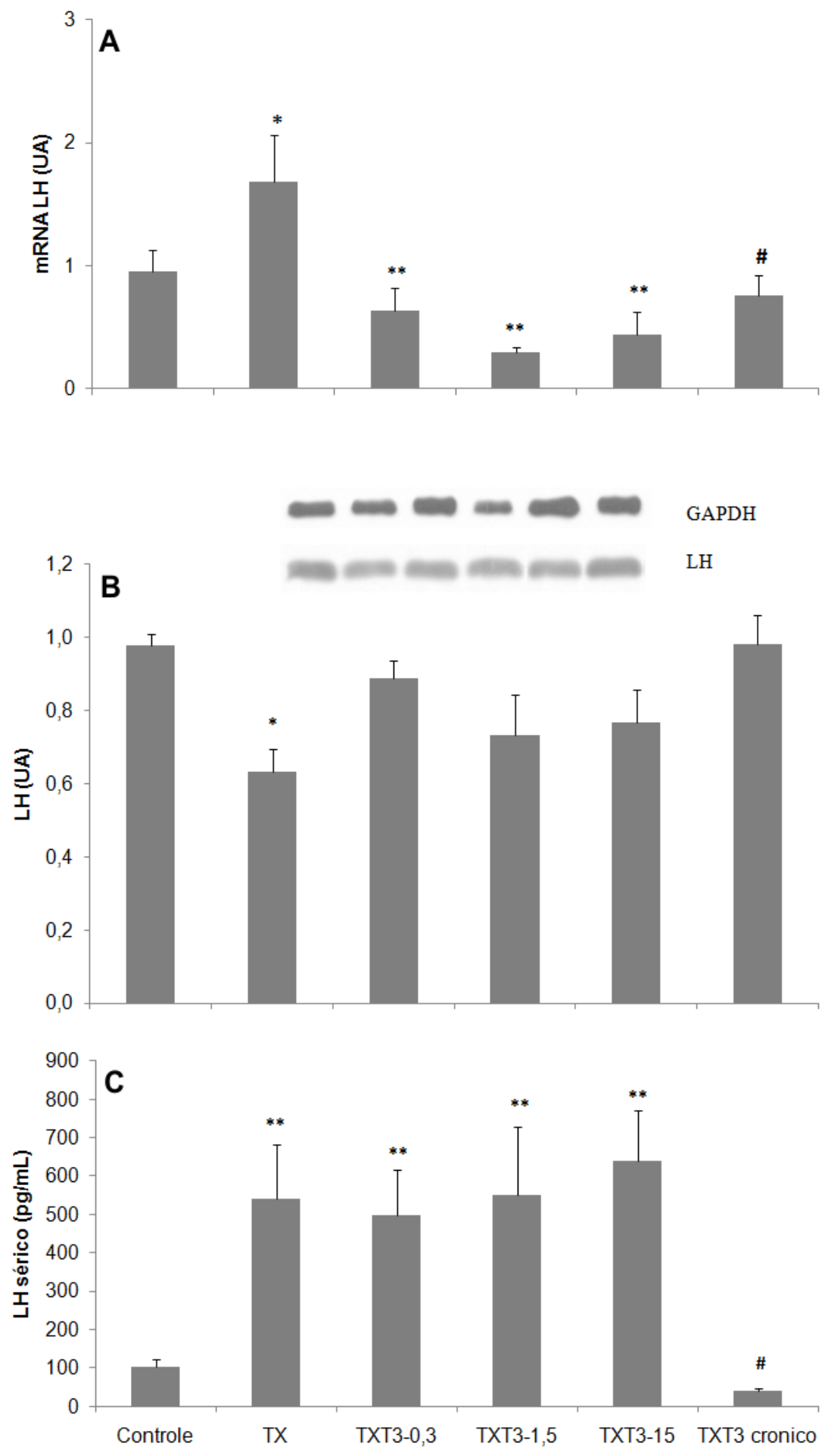

Figura 4.4 - Quantificações do mRNA (A), da proteína (B) e da concentração sérica (C) de ${ }_{\beta} \mathrm{LH}$ em animais controle, hipotireoideos (TX) e tratados com $\mathrm{T}_{3}$. Os valores estão expressos em média \pm E.P.M. Teste ANOVA e pós-teste de Tukey HSD, *p<0,05 e **p<0,01 vs controle; \#p<0,05 vs TX, $\mathrm{n}=9$ a 11 animais/grupo/procedimento 


\subsection{Perfil polissomal}

O perfil polissomal não se alterou entre os diferentes grupos experimentais, mas a quantidade de transcrito associado aos ribossomos foi diferente. O tratamento com T3 aumentou a associação do mRNA aos ribossomos, sendo que o grupo tratado com a dose de 0,3 $\mu \mathrm{g} / 100 \mathrm{~g}$ PC mostrou resultado semelhante ao grupo controle. Já os animais tratados cronicamente apresentaram associação ao ribossomo maior que todos os demais grupos $(\mathrm{p}<0,05)$ (Figura 4.5).

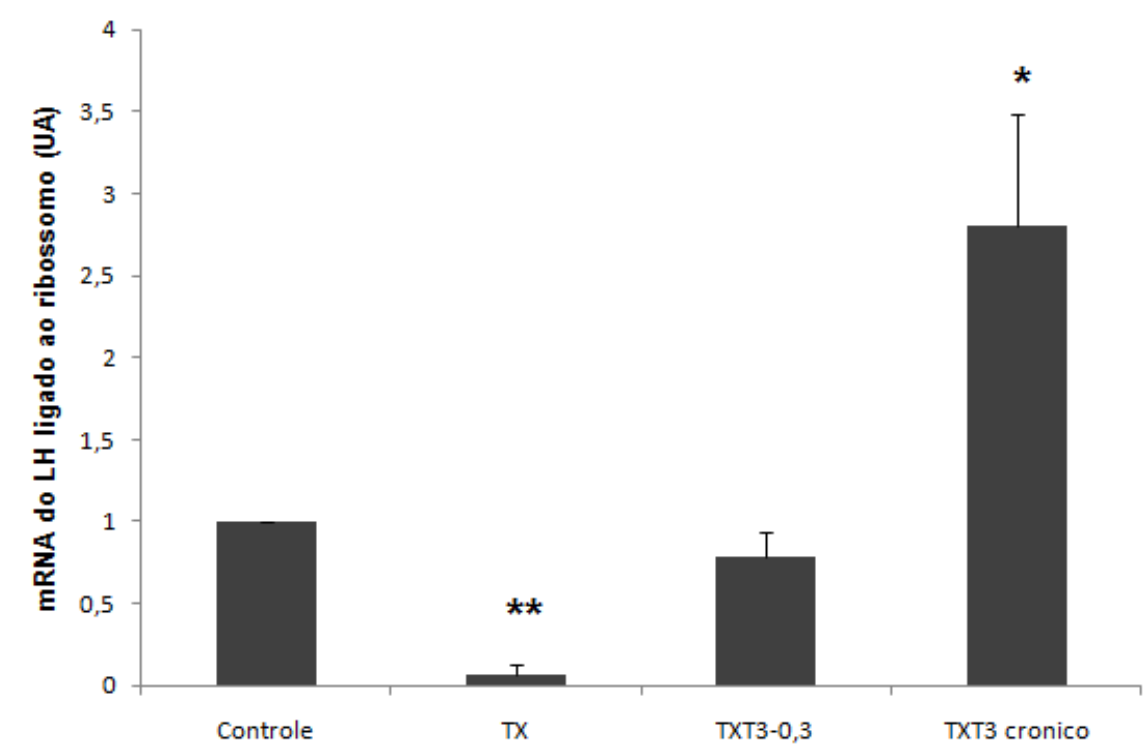

Figura 4.5 - O tratamento com T3 elevou o conteúdo de mRNA do ${ }_{\beta} \mathrm{LH}$ ligado ao ribossomo. Observa-se o perfil polissomal de mRNA do ${ }_{\beta} \mathrm{LH}$ avaliado por PCR em tempo real. Os valores estão expressos em média \pm E.P.M. ANOVA e pós-teste de Tukey, ${ }^{*} \mathrm{p}<0,05$ e ** $\mathrm{p}<0,01, \mathrm{~N}=3$ (x 10 hipófises/grupo)

\subsection{Análise do comprimento da cauda poli(A) do mRNA}

A redução no comprimento da cauda poli(A) observada no hipotireoidismo não foi alterada pelos tratamentos com T3 ( $\mathrm{p}<0,05$ vs controle). A figura 4.6 do lado esquerdo mostra o padrão de smear dos produtos de PCR em gel de agarose a 2,5\% corado com brometo de etídeo, e o lado direito da figura representa o comprimento da cauda poli(A) dos mRNAs dos grupos experimentais em estudo.. O tamanho mínimo do amplicon esperado foi de 128 pares de bases, que é relativo ao tamanho do fragmento de mRNA amplificado a partir da posição 
389 da sua sequência gênica até o sítio de poliadenilação. A cauda poli(A), portanto, corresponde ao comprimento total do fragmento gerado na amplificação do mRNA da amostra, subtraindo-se $128 \mathrm{pb}$.

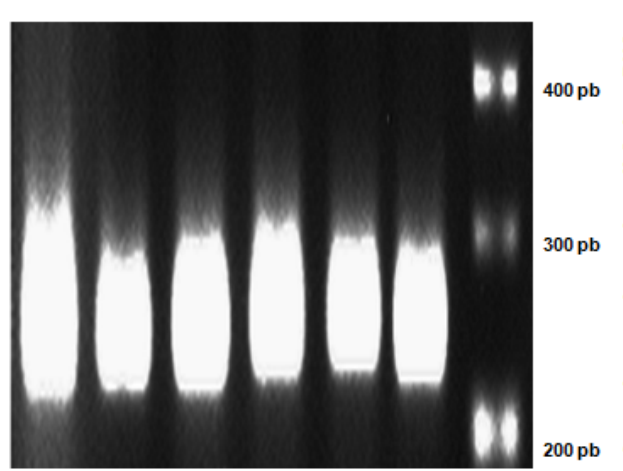

(A) $\quad(B) \quad(C) \quad(D) \quad(E) \quad(F)$

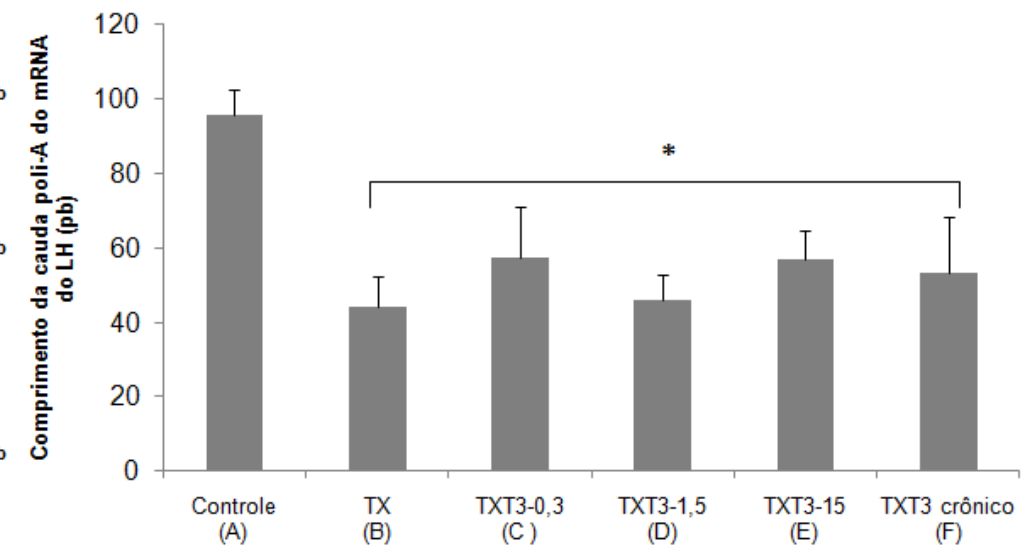

(A)

Figura 4.6 - Análise do comprimento da cauda poli(A) do mRNA do ${ }_{\beta} \mathrm{LH}$ pelo método de RACE-PAT. Observa-se que o tratamento com T3 não altera a redução ocorrida no TX. Os valores estão expressos em média \pm E.P.M. ANOVA e pós-teste de Tukey, ${ }^{*} \mathrm{p}<0,05, \mathrm{n}=8 / 9$ animais/grupo

\subsection{Morfologia do gonadotrofo por imunohistoquímica}

Nesse ensaio imunohistoquímico e histoquímico, utilizou-se a tripla marcação analisada em microscopia de fluorescência, onde o núcleo das células foi corado em azul pelo DAPI, os grânulos de LH corados em verde pelo FITC e a actina polimerizada em vermelho corada pela rodamina (Figura 4.7).

No grupo controle observaram-se gonadotrofos com marcação para LH distribuídas de forma difusa pelo citoplasma. É possível identificar uma concentração elevada de grânulos distribuídos em torno de vasos sanguíneos (VS, setas, A). O citoesqueleto apresentou regiões contendo actina polimerizada, que se caracterizam pela tonalidade vermelha mais intensa (B). A sobreposição das duas imagens revelou uma área de marcação de LH associado à actina polimerizada e outra área não associada (setas, C).

No grupo TX observou-se menor número de células marcadas, mas de intensa fluorescência (seta, D). A actina encontrou-se pouco polimerizada, o que pode ser percebido 
pela menor intensidade da coloração vermelha. Mas, em algumas áreas de marcação para LH, o citoesqueleto de actina encontrou-se organizado (seta, F).

No grupo tratado com T3 em dose fisiológica (TXT3-0,3) foram observadas mais células marcadas, de forma difusa, que se apresentaram em grupos, associado a um conteúdo citoplasmático difuso e granular de fluorescência intensa (G). O citoesqueleto de actina se reorganizou $(\mathrm{H})$, havendo algumas áreas de associação com grânulos de LH (seta, I).

Os grupos TXT3-1,5 (J, K, L) e TXT3-15 (M, N, O) apresentaram morfologia bastante semelhante ao grupo TXT3-0,3, previamente descrito.

Já no grupo tratado com hormônio por 5 dias com a dose correspondente a $5 \mathrm{X}$ a fisiológica e que acarreta em hipertireoidismo (TXT3 crônico) observou-se um pequeno número de células esparsas com marcação difusa pelo citoplasma $(\mathrm{P})$. O citoesqueleto de actina mostrou-se polimerizado $(\mathrm{Q})$, havendo pequena associação dela na região onde o LH está localizado (S). 


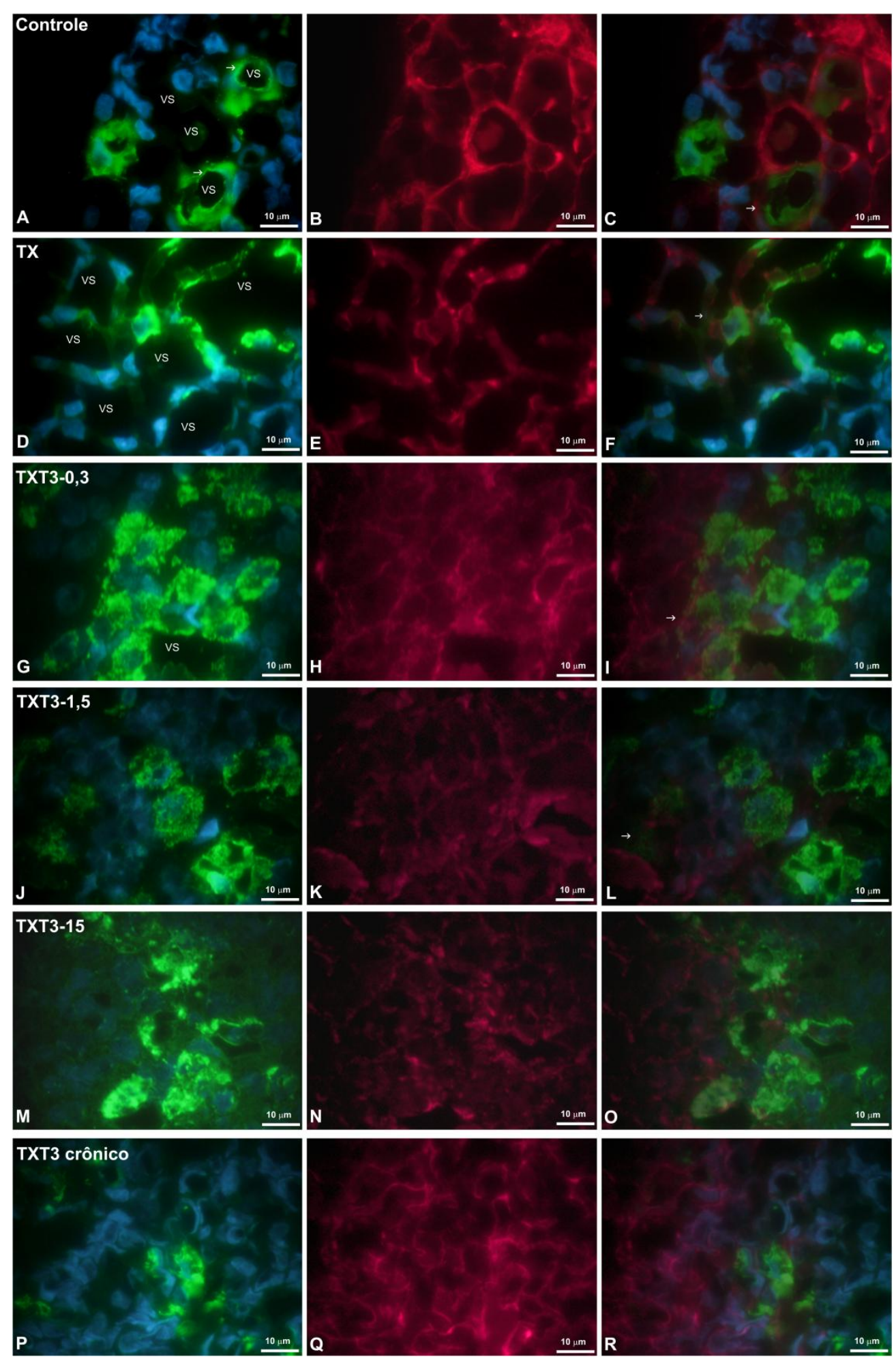

Figura 4.7 - Imunohistoquímica da hipófise para detecção de gonadotrofos em animais controle, TX e tratados com T3 marcados para LH. Observam-se em azul os núcleos celulares; em verde, observa-se o LH; em vermelho, a actina polimerizada do citoesqueleto. $n=5 / 6$ animais por grupo. Magnitude 100X. Barra de escala: $10 \mu \mathrm{m}$ 


\subsection{LH sérico após 1, 2 e 3 horas do tratamento com T3}

A avaliação da concentração sérica de LH após 1, 2 e 3 horas de tratamentos mostrou variação nesse parâmetro, em todos os grupos estudados. O LH sérico diminuiu com o decorrer do tempo de tratamento, com um efeito mais evidente no grupo tratado com a dose fisiológica de T3 (Fig 4.8 A).
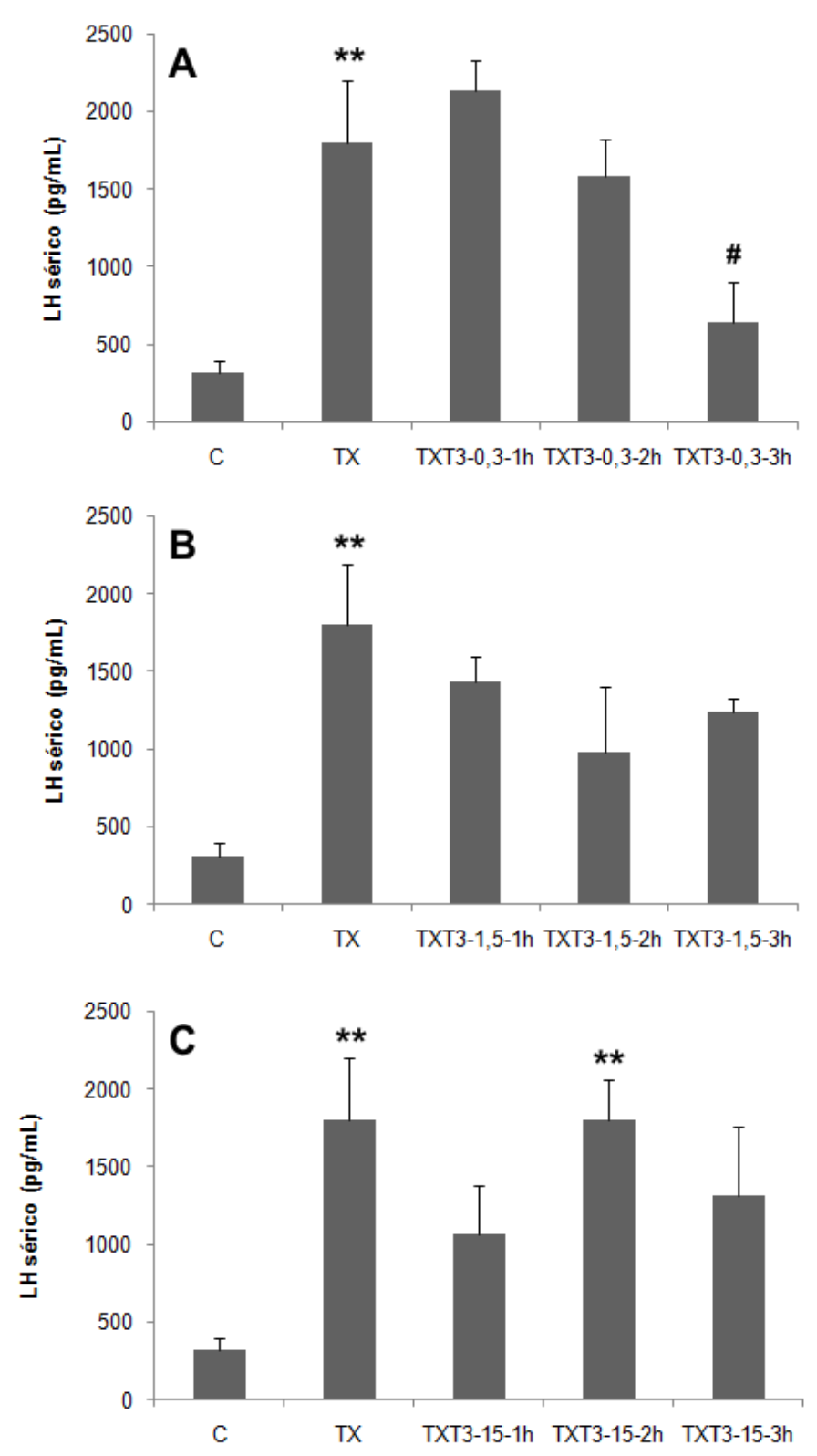

Figura 4.8 - Concentração sérica de ${ }_{\beta} \mathrm{LH}$ em animais controle, hipotireoideos (TX) e tratados com $\mathrm{T}_{3}$ nas doses de 0,3 (A), 1,5 (B) e 15 (C) $\mu \mathrm{g} / 100 \mathrm{~g}$ PC após 1,2 e $3 \mathrm{~h}$ do tratamento. Os valores estão expressos em média \pm E.P.M. Teste ANOVA e pós-teste de Tukey HSD, $* * \mathrm{p}<0,01$ vs controle; $\# \mathrm{p}<0,05$ vs $\mathrm{TX}, \mathrm{n}=5$ a 8 animais/grupo 


\subsubsection{Hormônio folículo estimulante: expressão, produção e secreção}

\subsection{Expressão gênica e protéica e concentrações séricas}

A análise da expressão do ${ }_{\beta} \mathrm{FSH}$ evidenciou grande redução de seu mRNA nos grupos tratados agudamente com T3, tanto em relação ao controle quanto em relação ao TX ( $\mathrm{p}<0,001)$. O tratamento crônico com T3 manteve o conteúdo deste transcrito semelhante ao observado no grupo hipotireoideo (elevado em relação ao grupo controle, p<0,05) (Figura 4.9 A).

O tratamento agudo com T3 aumentou na quantidade de proteína contida na hipófise em relação ao grupo TX $(\mathrm{p}<0,05)$. Já no grupo tratado cronicamente a elevação foi ainda maior, diferindo tanto do controle quanto do TX ( $p<0,01)$ (Figura 4.9 B).

O conteúdo de FSH sérico apresentou-se elevado nos animais tratados aguda e cronicamente com T3 em relação ao grupo TX, mas não diferiram do controle (Figura 4.9 C). 

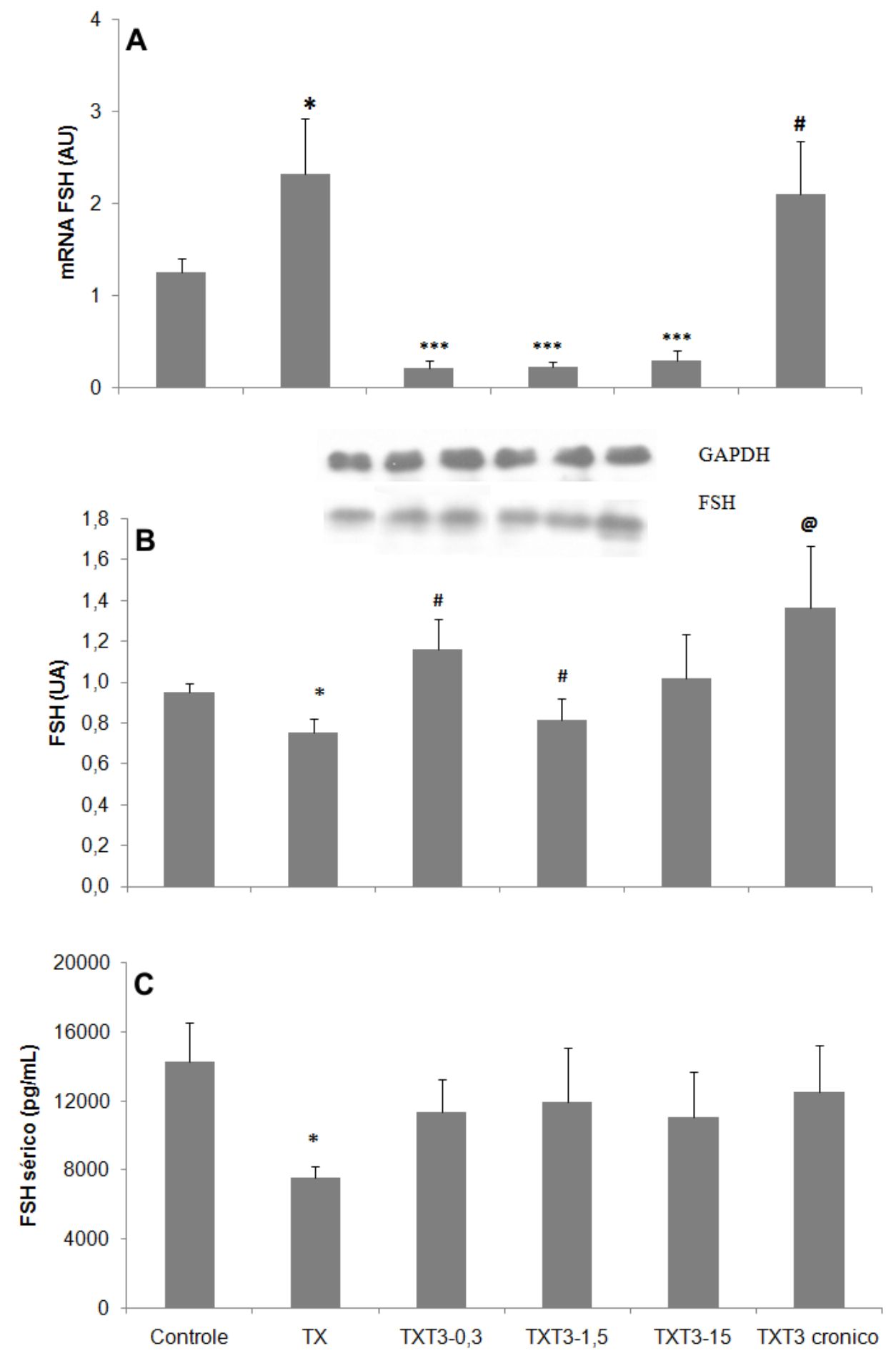

Figura 4.9 - Quantificações do mRNA (A), da proteína (B) e da concentração sérica (C) de ${ }_{\beta} \mathrm{FSH}$ em animais controle, hipotireoideos (TX) e tratados com $\mathrm{T}_{3}$. Os valores estão expressos em média \pm E.P.M. Teste ANOVA e pós-teste de Tukey HSD, *p<0,05 e ***p<0,001 vs controle; \# $\mathrm{p}<0,05$ e @ $\mathrm{p}<0,01$ vs controle e TX, $\mathrm{n}=9$ a 11 animais/ grupo/procedimento 


\subsection{Perfil polissomal}

O perfil polissomal não se alterou entre os diferentes grupos experimentais, mas a quantidade de transcrito associado aos ribossomos foi diferente. O tratamento com T3 aumentou a associação do mRNA aos ribossomos, retornando aos valores observados no grupo controle tanto para o tratamento agudo quanto para o tratamento crônico $(\mathrm{p}<0,01)$ (Figura 4.10).

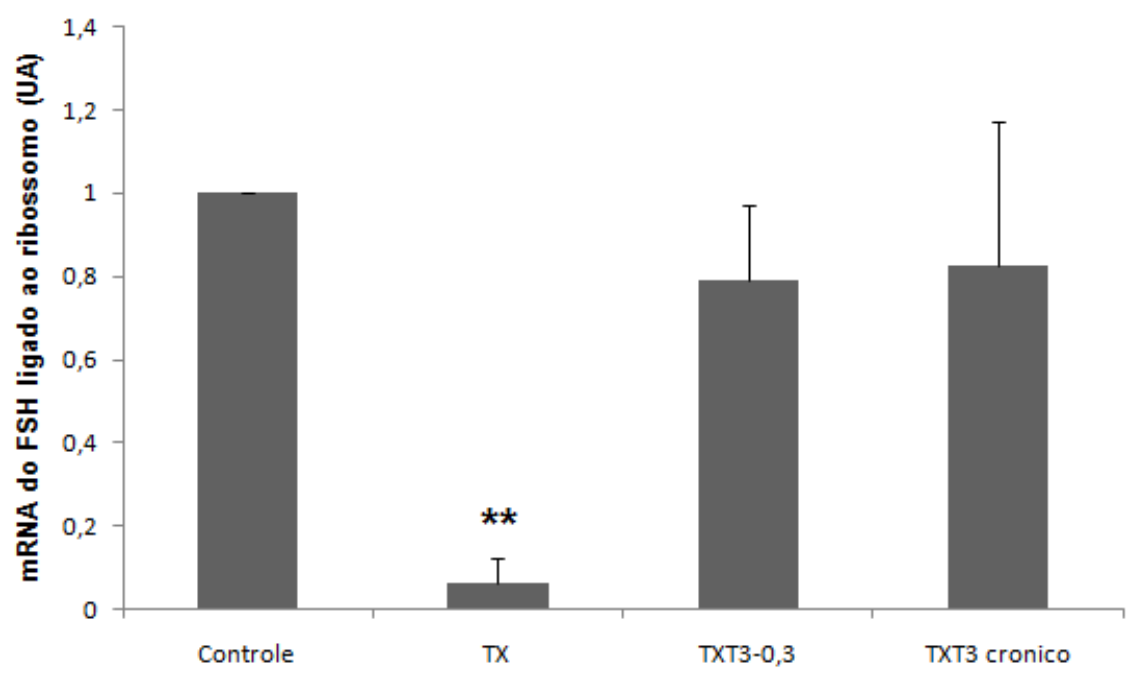

Figura 4.10 - O tratamento com T3 elevou o conteúdo de mRNA do ${ }_{\beta} \mathrm{FSH}$ ligado ao ribossomo. Observa-se o perfil polissomal de mRNA do ${ }_{\beta} \mathrm{FSH}$ avaliado por PCR em tempo real. Os valores estão expressos em média \pm E.P.M. Teste ANOVA e pós-teste de Tukey, $* * \mathrm{p}<0,01, \mathrm{~N}=3$ (x 10 hipófises/grupo)

\subsection{Morfologia do gonadotrofo por imunohistoquímica}

Assim como para o LH, utilizou-se a tripla marcação analisada em microscopia de fluorescência, onde o núcleo das células foi corado em azul pelo DAPI, os grânulos de FSH corados em verde pelo FITC e a actina polimerizada, em vermelho, corada pela rodamina (Figura 4.11).

No grupo controle observaram-se gonadotrofos com grande quantidade de grânulos marcados para FSH, tanto no citoplasma quanto na região perinuclear (A). O citoesqueleto de actina mostrou-se organizado (B), havendo poucas áreas de associação entre citoesqueleto organizado e grânulos de secreção (C). 
No grupo TX observou-se redução no número de células marcadas e poucos grânulos citoplasmáticos. O citoesqueleto apresentou-se desorganizado (E) e com poucas áreas de associação entre grânulos e organização (F).

No grupo agudo TXT3-0,3 observou-se maior número de células marcadas do que no grupo TX (G). O citoesqueleto de actina mostrou-se polimerizado em algumas áreas $(\mathrm{H})$.

Os grupos TXT3-1,5 e TXT3-15 comportaram-se de forma semelhante, com maior número de células marcadas. Houve um aparente aumento do número de grânulos na região perivascular (J e M). O citoesqueleto apresentou um maior grau de polimerização ( $\mathrm{K}$ e $\mathrm{N}$ ), embora não tenha sido evidente a associação entre as duas marcações ( $\mathrm{L}$ e O).

No TXT3 crônico o número de gonadotrofos marcados foi semelhante aos tratamentos agudos, com padrão granular semelhante ao controle (P). O citoesqueleto de actina mostrouse bastante reagente à faloidina, com intensa polimerização (Q); em algumas áreas observouse a presença de grânulos próximos à região perivascular $(\mathrm{R})$. 

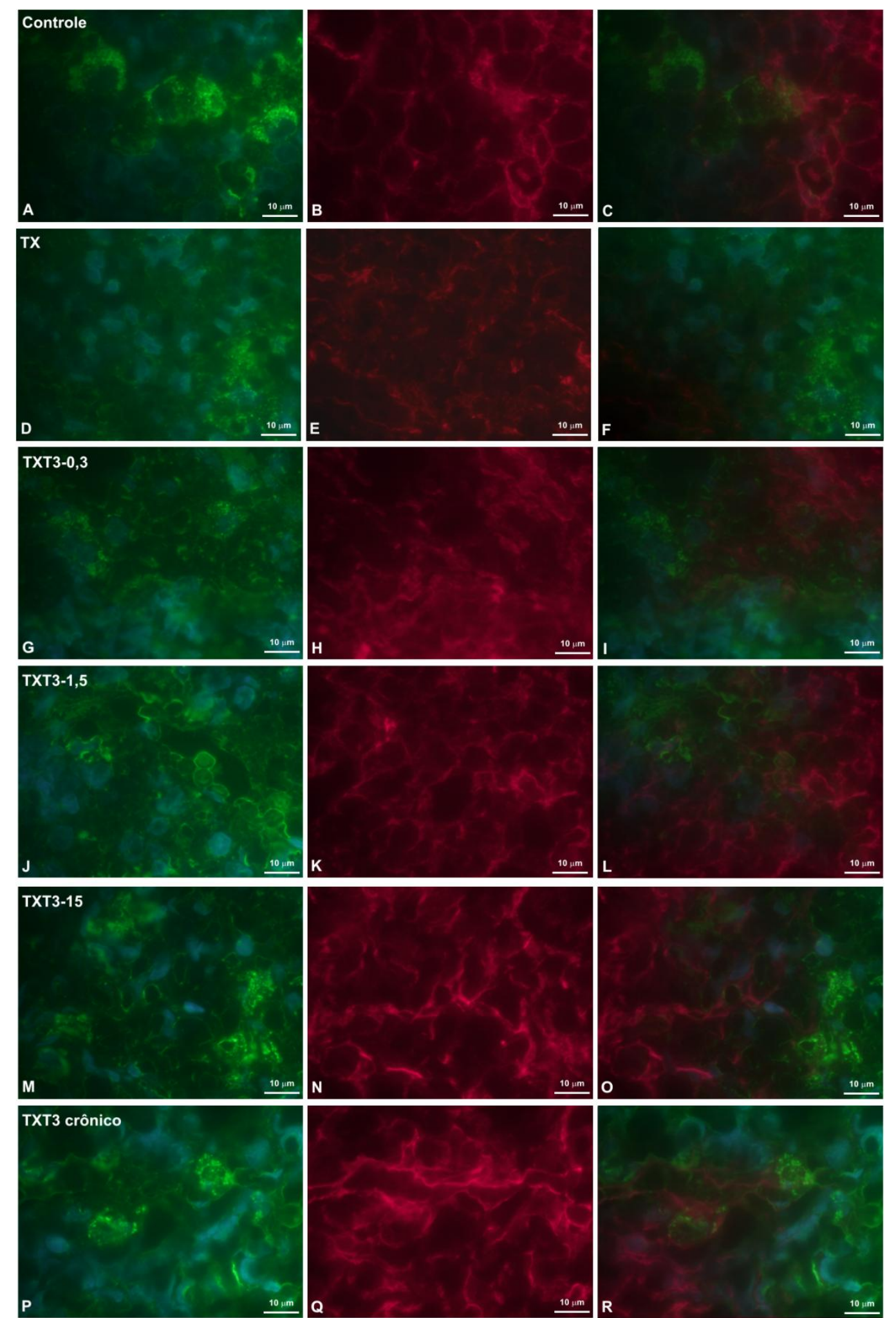

Figura 4.11 - Imunohistoquímica da hipófise para detecção de gonadotrofos em animais controle, TX e tratados com T3 marcados para FSH. Observam-se em azul os núcleos celulares; em verde, o LH; em vermelho, a actina polimerizada do citoesqueleto. $n=5 / 6$ animais por grupo. Magnitude 100X. Barra de escala: $10 \mu \mathrm{m}$. 


\subsection{FSH sérico após 1, 2 e 3 horas do tratamento com T3}

A elevação da concentração sérica observada após 30 minutos de tratamento se mantém no período de uma, duas e três horas após o tratamento com T3 em todas as doses utilizadas (Fig. 4.12).
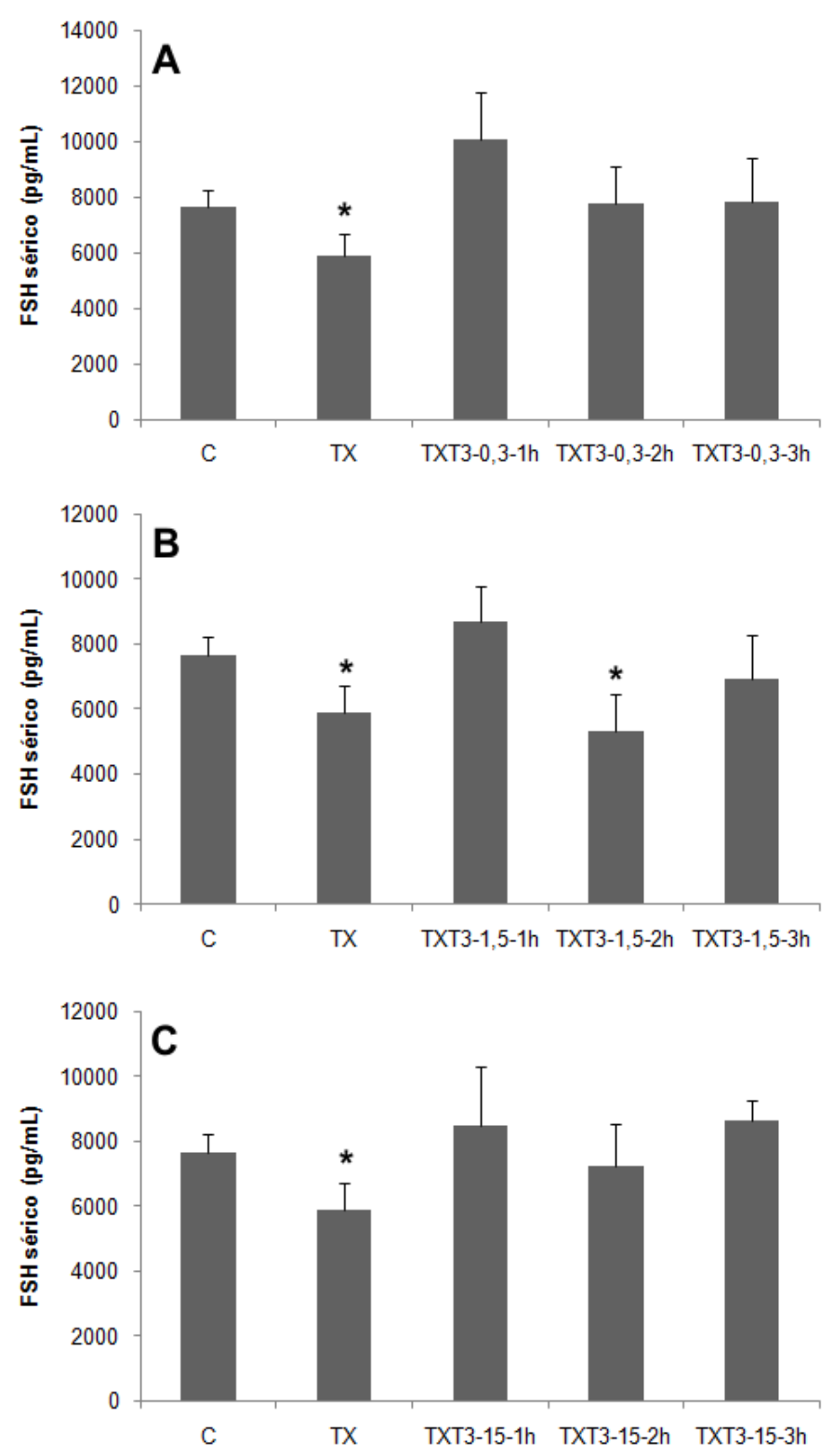

Figura 4.12 - Concentração sérica de ${ }_{\beta} \mathrm{FSH}$ em animais controle, hipotireoideos (TX) e tratados com $\mathrm{T}_{3}$ nas doses de 0,3 (A), 1,5 (B) e 15 (C) $\mu \mathrm{g} / 100 \mathrm{~g}$ PC após 1, 2 e $3 \mathrm{~h}$ do tratamento. Os valores estão expressos em média \pm E.P.M. Teste ANOVA e pós-teste de Tukey HSD, $* * \mathrm{p}<0,01$ vs controle; $\# \mathrm{p}<0,05$ vs $\mathrm{TX}, \mathrm{n}=5$ a 8 animais/grupo 


\subsubsection{Estudo dos tecidos periféricos}

\subsubsection{Peso dos testículos, epidídimos, vesícula seminal e próstata ventral}

Os grupos tratados de forma aguda com o T3 mantiveram as alterações observadas no TX em relação ao controle nos quatro tecidos avaliados: testículos (Figura 4.14 A), epidídimos (Figura 4.14 B), próstata (Figura 4.14 C) e vesícula seminal (Figura 4.13). O tratamento agudo com T3 não ocasionou nenhuma alteração estatisticamente significativa nesses tecidos. Mas no tratamento crônico a vesícula seminal apresentou maior quantidade de fluido $(\mathrm{p}<0,05)$.

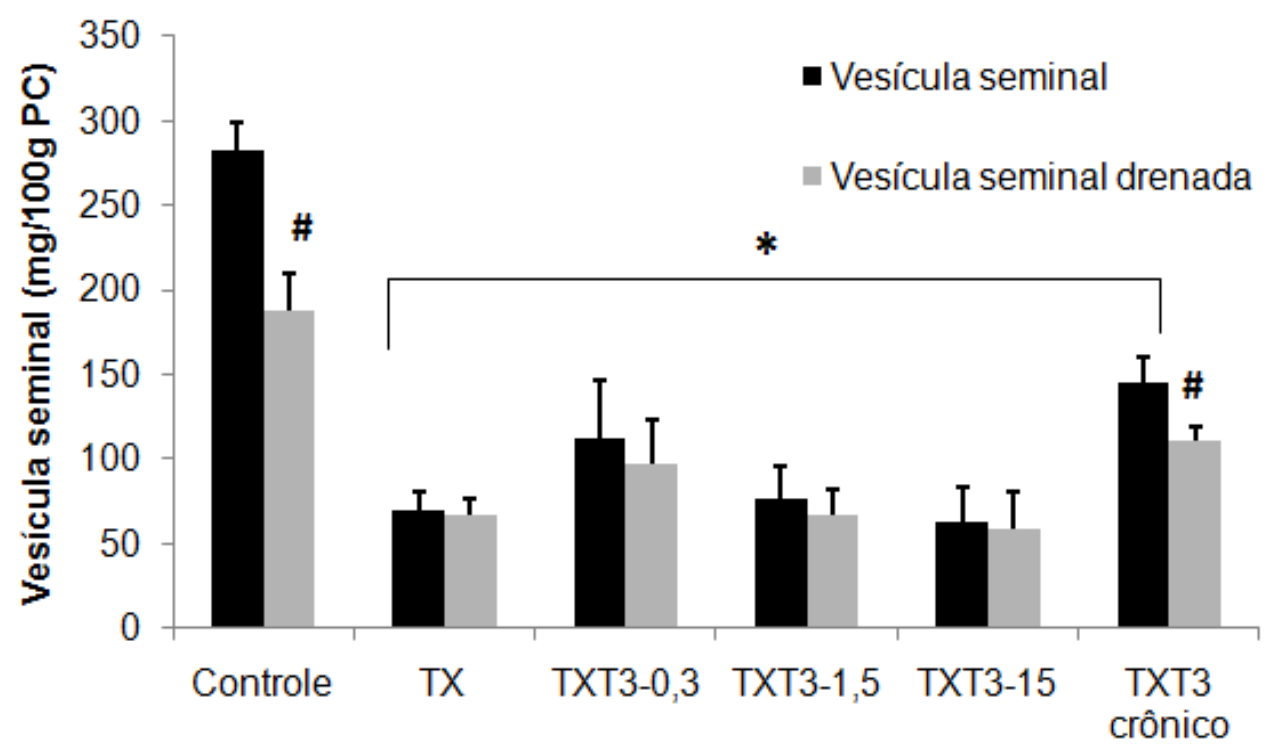

Figura 4.13 - Peso da vesícula seminal drenada e não drenada $(\mathrm{mg} / 100 \mathrm{~g}$ PC) nos ratos controle, TX e tratados com T3. Os valores estão expressos em média \pm E.P.M. Teste two-way ANOVA e pós-teste de Tukey HSD, $\mathrm{n}=9$ a 11 animais/grupo/procedimento. ${ }^{*} p<0,05$ vesícula seminal controle e \# $p<0,01$ vesícula seminal drenada. 

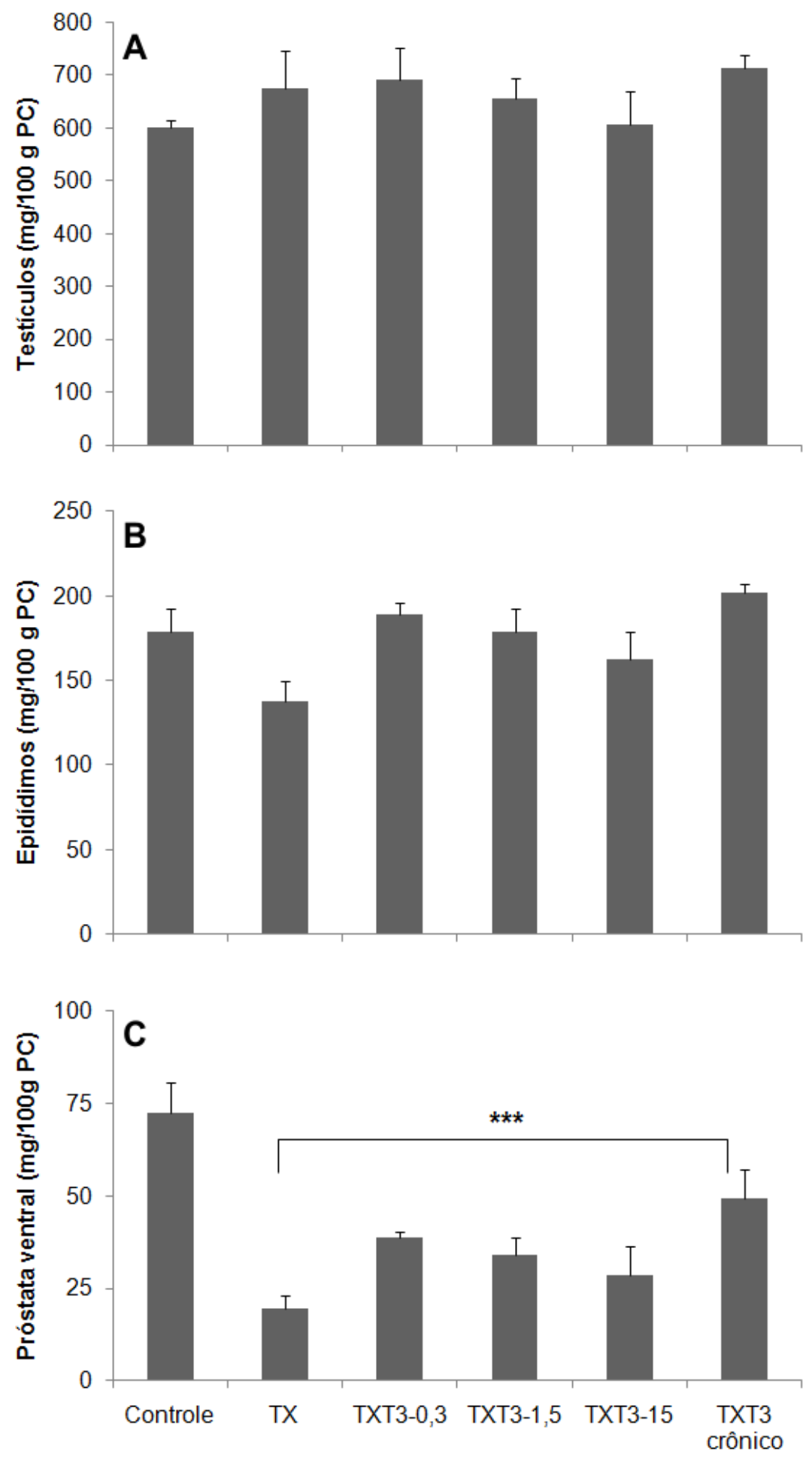

Figura 4.14 - (A) Peso testicular (mg/100 g PC), (B) Peso epididimal (mg/100g PC) e (C) Peso da próstata ventral (mg/100g PC) nos ratos controle, TX e tratados com T3. Os valores estão expressos em média \pm E.P.M. Teste ANOVA e pós-teste de Tukey HSD, $\mathrm{n}=9$ a 11 animais/grupo/procedimento. $* * * p<0,001$. 


\subsubsection{Dosagem sérica de testosterona}

A testosterona sérica dos animais tratados com T3 não se alterou em relação ao grupo TX, mantendo a redução em relação ao grupo controle $(\mathrm{p}<0,01)$. O grupo tratado com T3 crônico apresentou concentração sérica de testosterona $<0,008 \mathrm{ng} / \mathrm{mL}$, que foi a sensibilidade mínima do ensaio utilizado (Figura 4.15).

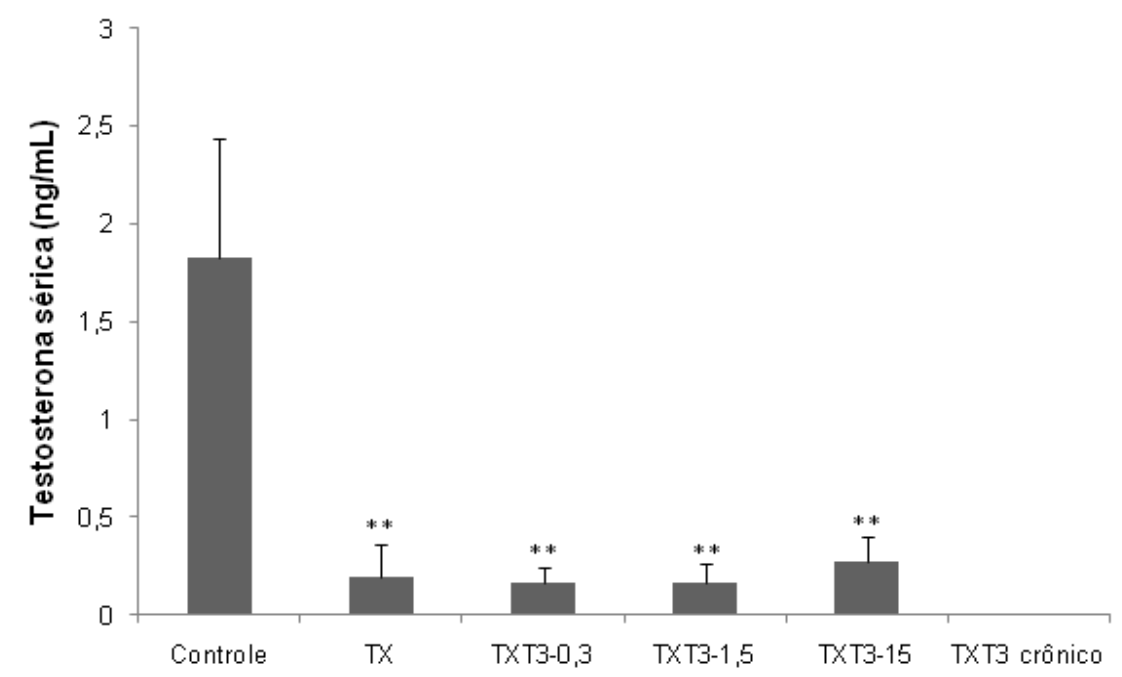

Figura 4.15 - Testosterona sérica $(\mathrm{ng} / \mathrm{mL})$ em animais controle, hipotireóideos (TX) e tratados com T3. Os valores estão expressos em média \pm E.P.M. Teste ANOVA e pós-teste de Tukey HSD, $\mathrm{n}=9$ a 11 animais/grupo/procedimento. ${ }^{* *} \mathrm{p}<0,01$

\subsubsection{Expressão testicular de receptores de andrógenos e de $\mathrm{LH}$}

A expressão do mRNA do receptor de andrógenos (AR) não foi alterada pelo hipotireoidismo e nem pelo tratamento agudo ou crônico com HT (Figura 4.16 A). Já a expressão protéica apresentou-se elevada no hipotireoidismo, sendo restabelecida nos tratamentos agudos TxT3-0,3 e TXT3-1,5. O tratamento crônico resultou numa grande elevação da expressão dessa proteína (Figura 4.16 B).

O hipotireoidismo elevou a expressão do mRNA do receptor de LH (LHR). E os tratamentos agudos e crônicos restabeleceram a sua expressão, retornando a valores não diferentes do controle, exceto no grupo TXT3-15, que manteve a elevação observada no TX (Figura 4.17 A). Ao contrário do observado para o mRNA, a expressão protéica do LHR foi menor no hipotireoidismo. O tratamento com HT restabeleceu essa expressão (Figura 4.17 B). 

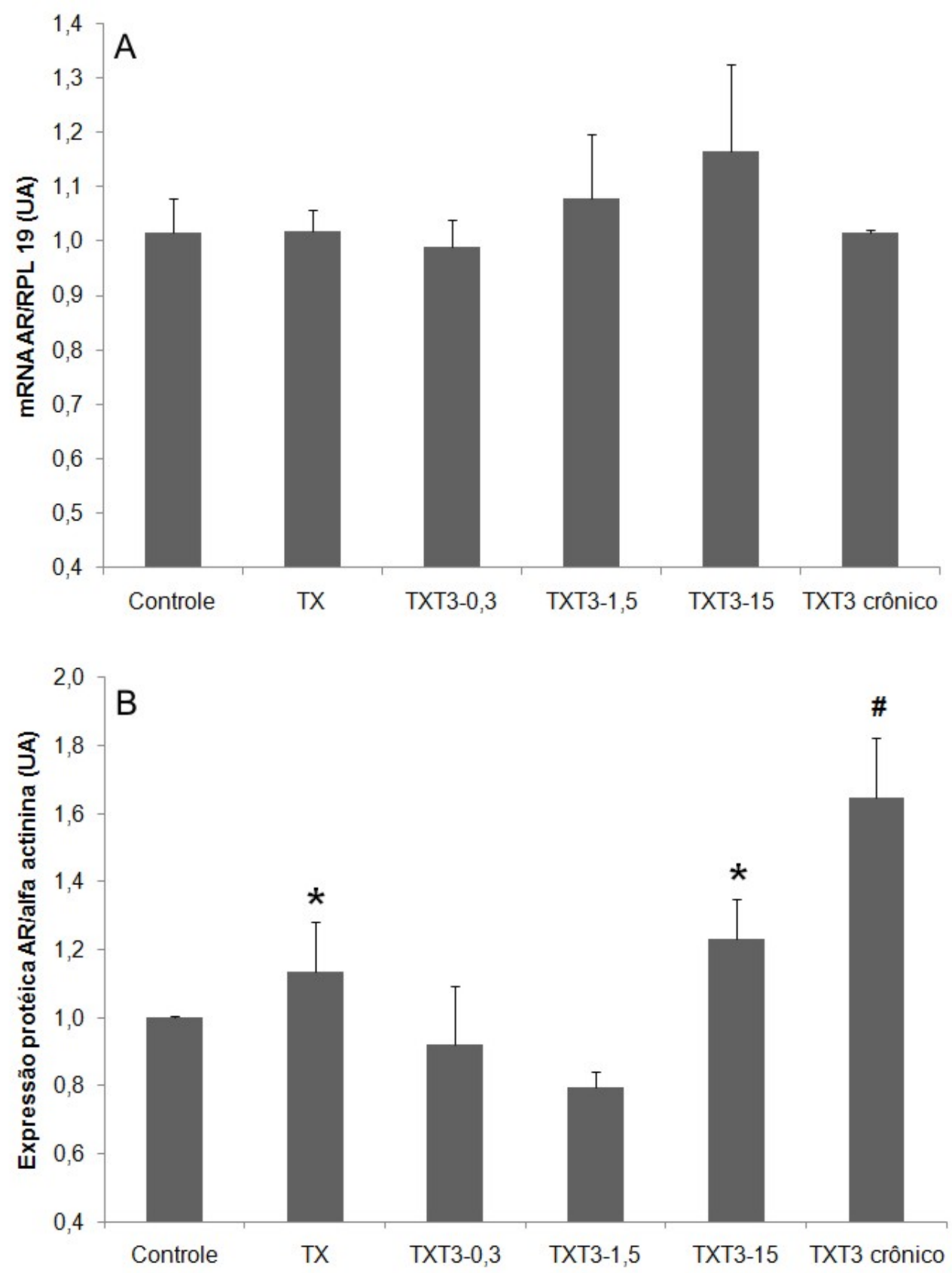

Receptor de andrógenos (110 KDa)

Alfa actinina (100 KDa)

Figura 4.16 - Expressão testicular (A- mRNA e B-proteína) de receptores de andrógenos em animais controle, TX e tratados com T3. Os valores representam média \pm E.P.M, Teste ANOVA e pós-teste de Tukey HSD, $\mathrm{n}=10$ animais/grupo/procedimento $* p<0.05$, $\# p<0,05$ vs todos os grupos 

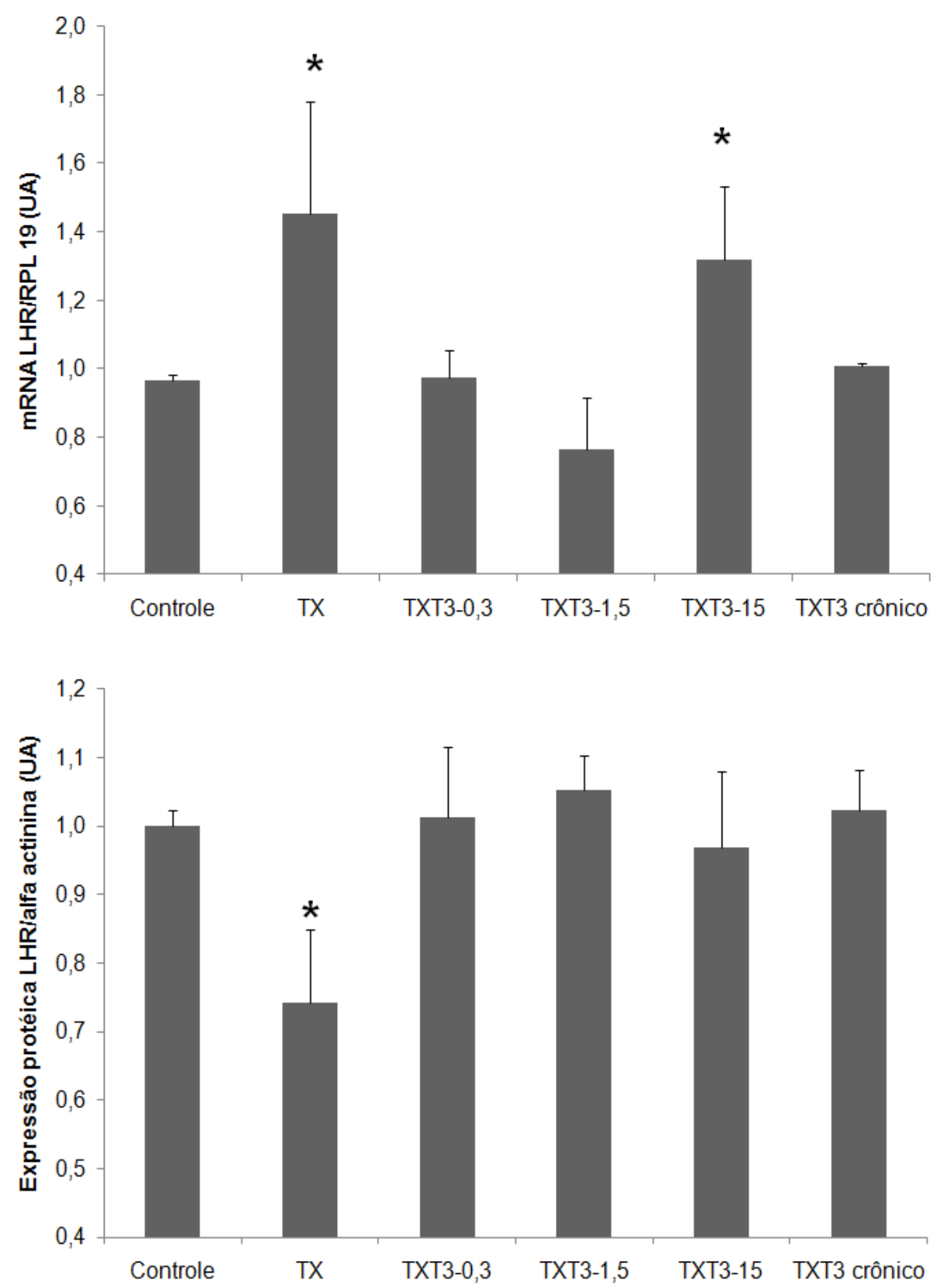

Alfa actinina $(100 \mathrm{KD})$

Receptor de LH (85 KD)

Figura 4.17 - Expressão testicular de receptor de LH (A- mRNA e B-proteína) em animais controle, TX e tratados com T3. Os valores representam média \pm E.P.M, Teste ANOVA e pósteste de Tukey HSD, $\mathrm{n}=10$ animais/grupo/procedimento $* p<0.05$ 


\subsubsection{Expressão epididimal de receptores de andrógenos}

Para mais acurada verificação dos efeitos do tratamento com HT, o epidídimo foi dividido em três porções macroscopicamente diferentes: cabeça, corpo e cauda. O trajeto espermático ocorre da cabeça em direção à cauda, e diferentes aspectos da maturação ocorrem nesses segmentos. Assim, pode haver respostas diferentes nesses segmentos em relação ao tratamento com HT.

De fato, quando se analisa a expressão dos ARs, parecem existir diferentes magnitudes de resposta ao HT. Com relação ao mRNA, o hipotireoidismo ocasionou diminuição de seu conteúdo em todos os segmentos estudados $(\mathrm{p}<0,05)$, e o tratamento com T3 agudo e crônico elevaram esse conteúdo aos valores observados ao controle. Mas parece que nos segmentos de cabeça e corpo essa elevação foi mais evidente que na cauda nos grupos TXT3-0,3 e TXT31,5. O tratamento crônico não produziu esse tipo de diferença entre segmentos. Nesse aspecto, embora todos os segmentos aumentem a expressão de AR em resposta ao tratamento com T3, a cabeça e o corpo parecem ser mais sensíveis ao HT (Figura 4.18 A).

Já o conteúdo protéico não se alterou na cabeça do epidídimo, em nenhum tratamento. O corpo e a cauda apresentaram elevação do conteúdo no hipotireoidismo e redução nos tratamentos com T3. 

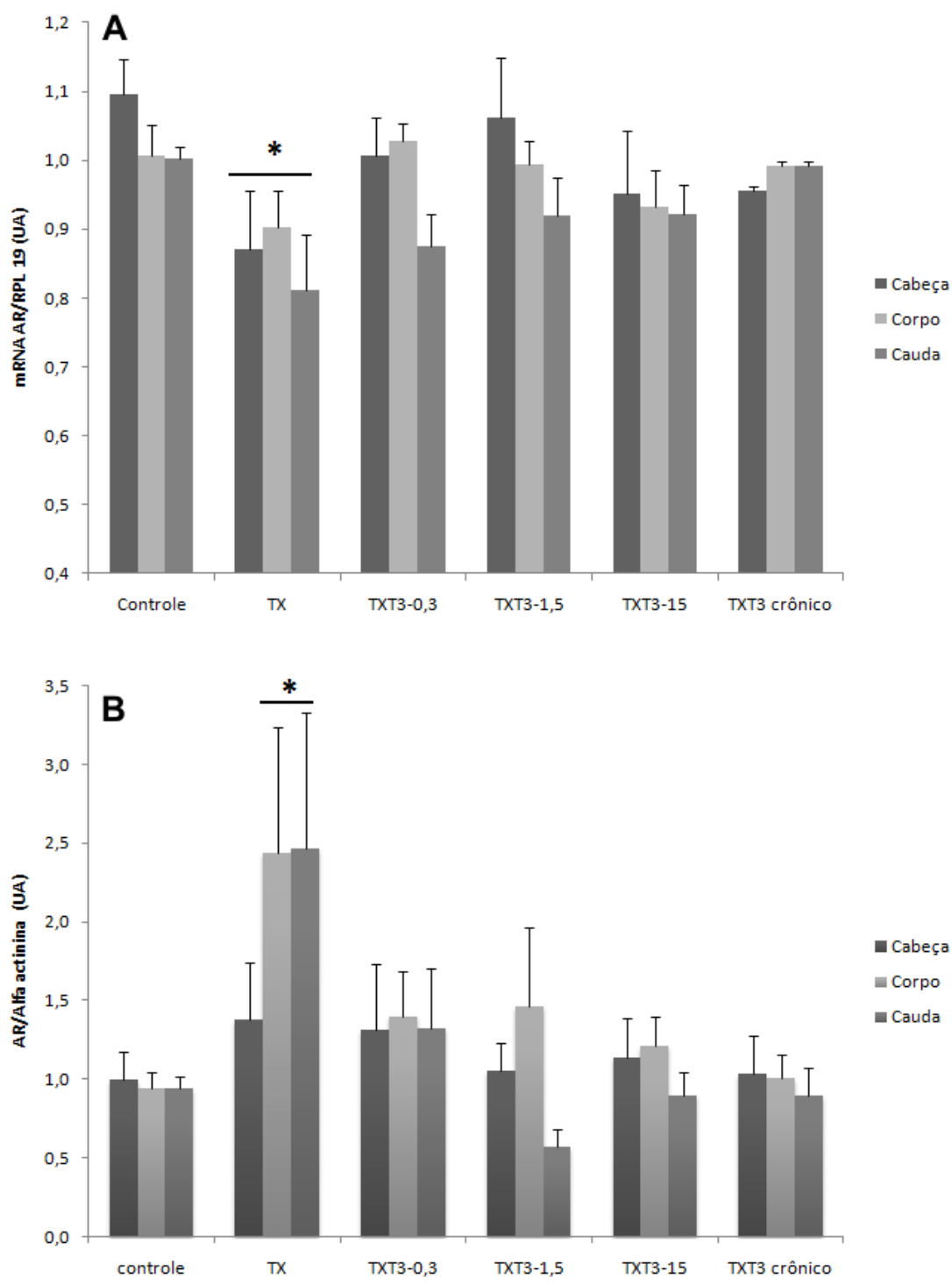

Cabeça

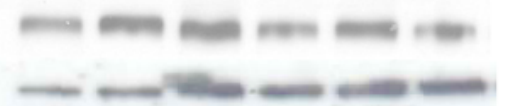

Corpo

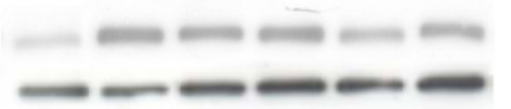

Cauda

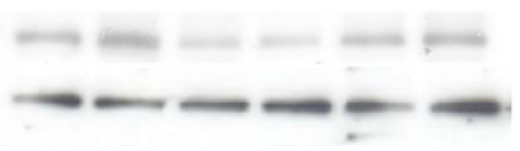

Receptor de andrógenos (110 KDa)

Alfa actinina (100 Kda)

Receptor de andrógenos (110 KDa)

Alfa actinina (100 Kda)

Receptor de andrógenos $(110 \mathrm{KDa})$

Alfa actinina (100 Kda)

Figura 4.18 - Expressão epididimal (mRNA) de receptores de andrógenos em animais controle, TX, tratados agudamente com T3 (TXT3-0,3, TXT3-1,5, TXT3-15) e crônico (TXT3 crônico). Os valores representam média \pm E.P.M, Teste ANOVA e pós-teste de Tukey HSD, $\mathrm{n}=10$ animais/grupo/procedimento $* p<0.05$ 


\subsection{DISCUSSÃO}

\subsubsection{Modulação do ${ }_{\beta} \mathrm{LH}$ pelo hormônio tireoideano}

O conteúdo protéico de ${ }_{\beta} \mathrm{LH}$ hipofisário foi restabelecido após trinta minutos do tratamento com o T3 em relação aos animais com hipotireoidismo, assemelhando-se ao grupo controle. A concentração sérica de LH não se alterou, estando elevada tanto no hipotireoidismo quanto nos tratamentos de trinta minutos. Mas, como esse período de trinta minutos coincide com a sua meia-vida plasmática (NORMAN e LITWACK, 1997), não seria esperada a ocorrência de alterações que levassem a uma diminuição sérica no período utilizado para esse tratamento. Contudo, o tratamento crônico com T3 promoveu redução do LH sérico.

A análise morfológica do gonadotrofo revelou aumento do número de células imunorreativas ao ${ }_{\beta} \mathrm{LH}$, associado a um conteúdo citoplasmático difuso e granular de fluorescência intensa. Alterações estas compatíveis com o estímulo celular (WATANABE et al., 1998; SANCHEZ-CRIADO et al., 2006; KITAHARA et al., 2007; SORENSON et al., 2007; GARRIDO-GRACIA et al., 2008).

O controle fisiológico do conteúdo de proteínas é realizado por vários mecanismos. Somando-se à taxa de transcrição e degradação protéica, a estabilidade do mRNA e a eficiência da tradução são dois importantes mecanismos que o controlam. Deste modo, a regulação do turnover do mRNA é uma etapa essencial para a avaliação da sua abundância e, portanto, da expressão gênica (CHENEVAL et al., 2010).

Como pode ser observado, após trinta minutos do tratamento com T3, houve diminuição do conteúdo hipofisário de mRNA do ${ }_{\beta} \mathrm{LH}$ em relação ao animais com hipotireoidismo. Essa diminuição do conteúdo de mRNA de LH observada concomitantemente ao aumento do conteúdo hipofisário de LH e da marcação para o mesmo nos gonadotrofos sugere fortemente que o T3 aumentou a taxa de tradução deste transcrito, por mecanismos pós-transcricionais, a julgar pela rapidez com que o efeito foi evidenciado (SHEUE-YANN et al., 2010) e pelo fato de não haver TRE no gene que codifica o LH (MEIKLE, 2004; TONI et al., 2005).

A taxa de tradução de um mRNA guarda relação direta com o comprimento da sua cauda poli(A), razão pela qual o comprimento da cauda poli(A) do mRNA do ${ }_{\beta} \mathrm{LH}$ foi avaliada. O comprimento da cauda poli(A) do mRNA do LH não diferiu nos tratamentos com $\mathrm{T}_{3}$ em relação ao hipotireoidismo, mantendo-se menor que o controle. Esse dado sugere que 
mRNA do ${ }_{\beta} \mathrm{LH}$ esteja menos estável e mais susceptível à ação das endonucleases (STATON et al., 2010), podendo representar uma possível via de regulação da sua meia-vida influenciada pelo T3, uma vez que o tratamento com T3 reduziu a quantidade deste transcrito.

Entretanto, a maior associação do mRNA do LH à maquinaria traducional, avaliada pelo perfil polissomal após trinta minutos do tratamento com T3, a qual apresentou-se cerca de treze vezes maior que a observada no hipotireoidismo, assemelhando-se ao grupo controle, reforça a hipótese de que o processo de tradução tenha sido estimulado, como previamente observado em somatotrofos (SILVA et al., 2010).

Decorridas 1, 2 e 3 horas do tratamento com T3, a concentração sérica de LH foi reduzida aos valores observados ao grupo controle. Mas é apropriado considerar que, como discutido anteriormente no capítulo referente ao hipotireoidismo, o LH sérico estava elevado provavelmente por problemas decorrentes na sua excreção renal (GAY, 1974; KRETSER et al., 1973). Então, o resultado dessa análise sérica temporal reflete não só alterações na síntese, mas também na normalização na excreção do LH.

O estudo de Bruni et al. (1975), no qual o hipotireoidismo foi induzido após a castração, resultou num aumento maior na concentração sérica de LH do que o observado após a castração exclusivamente. E a administração de T4 reduz os valores de LH àqueles observados em ratos castrados. Esse fato pode também sugerir falhas no mecanismo de excreção hormonal.

Mas outras possíveis ações do HT sobre a produção hormonal foram investigadas. A ação direta do HT nos neurônios GnRH hipofisiotrópicos parece improvável. Entretanto, a inibição da pulsatilidade pelo HT sugere envolvimento neuroendócrino na sua regulação. Existem evidências de que o conteúdo de mRNA do beta LH, mas não do beta FSH, responde aos níveis de HT, e os receptores de HT são expressos em uma variabilidade de outros tipos celulares da hipófise anterior, incluindo os somatotrofos e lactotrofos. É possível ainda que HT exerça ação sobre os gonadotrofos indiretamente, pela indução da liberação parácrina de mediadores estimulatórios das células vizinhas (TONI, 2005).

O grupo tratado cronicamente com T3 e que desenvolveu hipertireoidismo, apresentou uma taxa de tradução ainda mais elevada que no tratamento de trinta minutos e uma concentração sérica de LH menor que o controle. Talvez isso possa ser explicado por uma maior excreção, pois o hipertireoidismo afeta a função renal de maneira inversa ao hipotireoidismo, aumentando a filtração glomerular e o fluxo plasmático renal (IGLESIAS e DIEZ, 2009). 


\subsubsection{Modulação do ${ }_{\beta} \mathrm{FSH}$ pelo hormônio tireoideano}

Para o ${ }_{\beta} \mathrm{FSH}$, o tratamento agudo causou uma intensa redução no mRNA, ao passo que o conteúdo protéico hipofisário elevou-se significativamente, sendo maior do que o observado no grupo controle. A elevação protéica confirmou-se também pela imunohistoquímica, que revelou grande quantidade de grânulos de FSH em todas as regiões da célula. A análise do perfil polissomal mostrou aumento na associação do mRNA à maquinaria traducional, o que corrobora com o aumento dos níveis protéicos. A concentração sérica foi restabelecida após trinta minutos do tratamento com T3, mantendo-se pelas três horas subsequentes ao tratamento. As etapas da regulação da transcrição e da tradução discutidas para o LH podem ser consideradas também para o FSH. O hipertireoidismo elevou significativamente o mRNA e a proteína do FSH hipofisário, mas a associação ao ribossomo e a concentração sérica mantiveram-se semelhantes ao controle. As etapas da regulação da transcrição e da tradução discutidas para o LH podem ser consideradas também para o FSH.

\subsubsection{Modulação do citoesqueleto de actina do gonadotrofo pelo hormônio tireoideano}

$\mathrm{O}$ citoesqueleto de actina desempenha papel fundamental em processos biológicos essenciais, como a migração celular, a determinação da forma da célula e o trânsito vesicular. A actina realiza um processo dinâmico no qual a forma monomérica (actina globular ou Gactina) se polimeriza em filamentos (actina filamentosa ou F-actina), sendo este processo reversível (MIRALES e VISA, 2006; FIRAT-KARALAR e WELCH, 2011). Dessa forma, a actina participa de processos envolvidos com a transcrição gênica, já que direciona fatores transcricionais ao núcleo, bem como se relaciona a eventos traducionais, ancorando mRNAs e fatores de alongamento, direcionando-os à maquinaria de tradução (GOULART-SILVA et al., 2006; SILVA et al., 2010).

O objetivo inicial para a avaliação da polimerização da actina relacionou-se ao fato da sua ação sobre o direcionamento do mRNA para a maquinaria de tradução e a sua relação com o processo de exocitose, como observado por Goulart-Silva et al. (2006) em somatotrofos. Entretanto, com os resultados obtidos neste estudo, para os gonadotrofos não foi observada relação entre as áreas imunorreativas ao ${ }_{\beta} \mathrm{LH}$ no ensaio de imunohistoquímica e as áreas de maior polimerização da actina após o tratamento com T3, tanto agudo, quanto crônico. Mas no hipotireoidismo, a menor polimerização da actina pode ter contribuído para a 
menor associação do mRNA do LH e do FSH à maquinaria traducional, uma vez que o conteúdo total encontrou-se bastante elevado e a associação ao ribossomo bastante reduzida.

4.3.4 Modulação da concentração sérica de testosterona e da expressão dos receptores de LH e de andrógenos pelo hormônio tireoideano

O LH atua sobre a célula testicular de Leydig através da ligação ao seu receptor, que se encontra na membrana plasmática, desencadeando a produção de testosterona (CHEN et al., 2009). A testosterona origina-se da conversão do colesterol, e uma etapa inicial e fundamental desse processo é o transporte desse substrato até o retículo endoplasmático mediado pela proteína StAR (steroidogenic acute regulatory protein) (STOCCO e CLARK, 1996).

Estudos em células de Leydig de camundongos pré-púberes com hipotireoidismo (MANNA et al., 2001) e em células tumorais de Leydig (MANNA et al., 1999) demonstraram que o T3 estimula a expressão gênica da proteína StAR e, consequentemente, a esteroidogênese. Mas, no presente estudo, a testosterona sérica dos animais tratados com T3 e avaliados após trinta minutos não foi alterada em relação ao hipotireoidismo, mantendo-se bastante reduzida. É provável que esse intervalo entre a administração de T3 e a averiguação dos seus efeitos não tenha sido suficiente para a realização de todas as etapas da esteroidogênese, pois, em humanos, o aumento da concentração sérica ocorre somente após três horas do tratamento com HT (LOVEJOY et al., 1997). Todavia no grupo com hipertireoidismo, a testosterona sérica foi ainda mais reduzida, o que pode sugerir que a ação do T3 em dose suprafisiológica e em período mais longo desencadeie outros mecanismos, ainda não estudados, que não acarretam na elevação da testosterona sérica.

Paralelamente, observou-se que a expressão gênica do receptor de LH foi estimulada após o tratamento agudo com T3, retornando ao observado para o grupo controle. Manna et al. (2001) identificaram na região promotora do gene do receptor de LH, a 173 pares de base acima do sítio de início de transcrição, um motif ligante de SF-1 (steroidogenic factor 1) envolvido na resposta ao T3. Assim, o T3 tanto estimularia o receptor de LH quanto o processo da esteroidogênese, após 8 horas do tratamento com HT.

O estudo de Manna et al. (2001) foi realizado em camundongos que desenvolveram hipotireoidismo durante a fase pré-puberal, ao passo que, nesta tese, se utilizaram ratos que desenvolveram hipotireoidismo na vida adulta. Isso é relevante, pois vários autores sugerem que os mecanismos mediados pelo HT sobre o sistema reprodutor até a puberdade são 
silenciados na vida adulta (MARAN, 2003; JANNINI et al., 1990 e 1995). Entretanto, a proximidade dos resultados obtidos neste estudo com os resultados de Manna et al. (2001) vem indicar que ao menos alguns desses efeitos possam ser mantidos.

Contudo, mesmo essa hipótese sendo verdadeira, ainda existe a possibilidade de esse efeito ocorrer somente no hipo e no hipertireoidismo. Porque o tratamento com T3 e a avaliação após trinta minutos pode não ser suficiente para a observação desse efeito que depende de eventos transcricionais. Assim, outros mecanismos podem estar relacionados ao efeito rápido do T3 sobre a expressão do receptor de LH.

A ação da testosterona é mediada pelos receptores de andrógenos (AR), que se localizam em órgãos reprodutivos masculinos e femininos e em tecidos não reprodutivos, como ossos e musculatura esquelética. A testosterona parece aumentar a expressão dos ARs, já que animais castrados apresentam um aumento da expressão do mRNA e uma diminuição da proteína desse receptor (PATRÃO et al., 2009).

Nos testículos, o AR está localizado nas células de Leydig, células peritubulares e de Sertoli, desempenhando importante papel na espermatogênese (ZHOU et al., 2011). O mRNA do AR testicular não se alterou nos grupos experimentais, mas a proteína apresentou redução nos tratamentos agudos com T3, retornando a valores observados para o controle, e elevação no grupo com hipertireoidismo. Considerando que a testosterona sérica manteve-se reduzida após trinta minutos do tratamento com T3 e indetectável no tratamento por cinco dias, pode-se inferir que esse resultado deve-se a uma ação direta do T3, por mecanismos que ainda necessitam ser investigados.

O epidídimo apresenta regiões morfológicas e funcionalmente distintas: o segmento inicial, a cabeça, o corpo e a cauda. A expressão diferenciada de genes ao longo desse trajeto estabelece um ambiente adequado à maturação dos espermatozóides (JELINSKI et al., 2007). Após trinta minutos do tratamento com T3, ocorreu o aumento do mRNA do AR em todos os segmentos do epidídimo, igualando-se ao observado no grupo controle. Apesar de o conteúdo de mRNA ter se elevado, a concentração protéica foi reduzida pelo tratamento com o T3, assemelhando-se ao grupo controle nos segmentos de corpo e cauda epididimais. O conteúdo de proteína no segmento de cabeça do epidídimo não se alterou em nenhuma das situações experimentais, inclusive no hipotireoidismo. Esses resultados sugerem que o T3 seja capaz de modular a expressão do AR, independentemente da testosterona sérica reduzida, opondo-se ao padrão de expressão observado em animais castrados.

De fato, o AR pode ser modulado por coativadores e repressores, mesmo na presença de um bloqueador da síntese de testosterona (WANG et al., 2004). Esse processo tem sido 
bastante investigado, pois no tratamento do câncer de próstata, a ativação do AR parece ocorrer mesmo sem a presença de um ligante androgênico (LABRI, 2011).

Uma possibilidade de modulação androgênica pelo T3 poderia ser a efetuada pela proteína ARA70 (androgen receptor-associated protein 70), um coativador específico do AR. Verificou-se que o T3 é capaz de estimular a expressão desse coativador, tendo sido identificada duas regiões contendo TREs acima da região regulatória desse gene. O ARA70 também suprimiu a sinalização pelo HT de uma maneira TRE dependente, ou seja, exercendo um feedback negativo (PEI-JU et al., 2007). Contudo, as ações rápidas do T3, aparentemente, não poderiam ser explicadas por esse mecanismo que depende da transcrição. 
Capítulo 5

\section{CONCLUSÕES}


1) O hipotireoidismo altera mecanismos moleculares da síntese e secreção de ${ }_{\beta} \mathrm{LH}$ :
a. elevando o conteúdo de mRNA;
b. reduzindo a estabilidade do mRNA por reduzir o tamanho da cauda poli(A);
c. reduzindo a associação do mRNA ao polissomo;
d. reduzindo o conteúdo protéico na hipófise observado pelo Western Blotting e pela imunohistoquímica;
e. ocasionando intensa elevação da concentração sérica.

2) O hipotireoidismo altera mecanismos moleculares da síntese e secreção de ${ }_{\beta} \mathrm{FSH}$ :
a. elevando o conteúdo de mRNA;
b. reduzindo a associação do mRNA ao polissomo;
c. reduzindo o conteúdo protéico na hipófise observado pelo Western Blotting e pela imunohistoquímica;
d. reduzindo a concentração sérica.

3) O hipotireoidismo afeta os órgãos andrógeno-dependentes:
a. reduzindo o peso da próstata e da vesícula seminal;
b. reduzindo a concentração sérica de testosterona;
c. alterando a morfometria dos túbulos seminíferos;
d. aumentando o mRNA e reduzindo a expressão protéica do receptor de LH. 
4) O hormônio tireoideano modula a expressão de ${ }_{\beta} \mathrm{LH}$ :
a. reduzindo o conteúdo de mRNA (aumentado pelo hipotireoidismo);
b. aumentando a associação do mRNA ao polissomo;
c. aumentando o conteúdo protéico na hipófise observado pelo Western Blotting e pela imunohistoquímica;
d. reduzindo a concentração sérica.

5) O hormônio tireoideano modula a expressão de ${ }_{\beta} \mathrm{FSH}$ :
a. reduzindo o conteúdo de mRNA;
b. aumentando a associação do mRNA ao polissomo;
c. aumentando o conteúdo protéico na hipófise observado pelo Western Blotting e pela imunohistoquímica;
d. aumentando a concentração sérica.

6) O hormônio tireoideano modula a expressão de receptores de $\mathrm{LH}$ e receptores de andrógenos (AR), independente da concentração sérica de testosterona:

a. reduzindo a expressão do mRNA e elevando a proteína do receptor de LH;

b. reduzindo a expressão da proteína do receptor de AR no tratamento agudo e elevando no hipertireoidismo;

c. reduzindo a expressão do mRNA em todos os segmentos do epidídimo e elevando a proteína no corpo e cauda do epidídimo do receptor de AR. 


\section{REFERÊNCIAS}




\section{REFERÊNCIAS $^{1}$}

ALKEMADE, A.; FRIESEMA, E. C.; KUIPER, G. G.; WIERSINGA, W. M.; SWAAB, D. F.; VISSER, T. J.; FLIERS, E. Novel neuroanatomical pathways for thyroid hormone action in the human anterior pituitary. European Journal of Endocrinology, v. 154, n. 3, p. 491-500, 2006.

ANTONY, F. F.; ARULDHAS, M. M.; UDHAYAKUMAR, R. C.; MARAN, R. R.; GOVINDARAJULU, P. Inhibition of Leydig cell activity in vivo and in vitro in hypothyroid rats. Journal of Endocrinology, v. 144, n. 2, p. 293-300, 1995.

ARIYARATANE, H. B. S.; MENDIS-HANDAGAMA, S. M. L. C.; MASON, J. Effects of T3 on testicular intersticial cells and androgen secretory capacity of the prepubertal rat. Biology of Reproduction, v. 63, p. 493-502, 2000.

ASCOLI, M.; FANELLI, F.; SEGALOFF, D. L. The lutropin/Choriogonadotropin receptor: a 2002 perspective. Endocrine Reviews, v. 23, n. 2, p. 141-174, 2002

BAGALOPAL, V.; PARKER, R. Polysomes, P bodies and stress granules: states and fates of eukariotic mRNAs. Current Opinion in Cell Biology, v. 21, n. 3, p. 403-408, 2009.

BARKER, S. B.; KLITGAARD, H. M. Metabolism of tissues excised from thyroxineinjected rats. American Journal of Physiology, v. 170, p. 81-86, 1952.

BIANCO, A. C.; KIMURA, E. T. Fisiologia da glândula tireóide. In: AIRES, M. M. (Ed.) Fisiologia. 3. ed. Rio de Janeiro: Editora Guanabara Koogan, 2008. p. 812-828.

BOUSFIELD, G. R.; JIA, L.; WARD, D. N. Gonadotropins: Chemistry and Biosynthesis. In: NEIL, J. D. (Ed.). Knobil and Neill's Physiology of Reproduction. 3rd. ed. Amsterdam: Ed Elsevier, 2006. p. 1581-1634.

BRADFORD, M. M. Bradford, A rapid and sensitive method for the quantitation of microgram quantities of protein utilizing the principle of protein-dye binding. Analytical Biochemistry, v. 72, p. 248-254, 1976.

BRUNI, J. F.; MARSHALL, S.; DIBBET, J. A.; MEITES, J. Effects of hyper- and hypothyroidism on serum LH and FSH levels in intact and gonadectomized male and female rats. Endocrinology, v. 97, n. 3, p. 558-563, 1975.

\footnotetext{
${ }^{1}$ De acordo com:

ASSOCIAÇÃO BRASILEIRA DE NORMAS TÉCNICAS. NBR 6023: Informação e documentação: referência: elaboração. Rio de Janeiro, 2002.
} 
BUCHAN, J. R.; PARKER, R. Eukariotic stress granules: the ins and outs of translation. Molecular Cell, v. 36, p. 932-941, 2009

BUZZARD, J. J.; MORRISON, J. R.; O'BRYAN, M.K.; SONG, Q.; WREFORD, N.G. Developmental expression of thyroid hormone receptors in the rat testis. Biology of Reproduction, v. 62, n. 3, p. 664-669, 2000.

CHAPIN, R. E.; STEVENS, J. T.; HUGHES, C. L.; KELCE, W. R.; HESS, R. A.; BASTON, G. P. Endocrine modulation of reproduction. Fundamental and Applied Toxicology, v. 29, p. $1-17,1996$.

CHEN, H.; GE, R. S.; ZIRKIN, B. R. Leydig cells: From stem cells to aging. Molecular and Cellular Endocrinology, v. 306, n. 1-2, p. 9-16, 2009.

CHENEVAL, D.; KASTELIC, T.; FUERST, P.; PARKER, C. N. A Review of Methods to Monitor the Modulation of mRNA Stability : A Novel Approach to Drug Discovery and Therapeutic Intervention. Journal of Biomolecular Screening, v. 15, n. 6, p. 609-622, 2010.

CHOMCZYNSKI, P.; SACCHI, N. Single-step method of RNA isolation by acid guanidinium thiocyanate-phenol-chloroform extraction. Analytical Biochemistry, v. 162, n. 1, p. 156-159, 1987.

COUNIS, R.; LAVERRIERE, J.; GARREL, G.; BLEUX, C.; COHEN-TANNOUDJI, J.; LERRANT, Y.; KOTTLER, M.; MAGRE, S. Gonadotropin- releasing hormone and the control of gonadotropo function. Reproduction, Nutrition and Development, v. 45, p. 243$254,2005$.

DANZI, S.; KLEIN, I. Post-transcriptional regulation of myosin heavy chain expression in the heart by triiodothyronine. American Journal of Physiology, v. 288, p. H455-H460, 2005.

DAREZZO, S.; INCERPI, S.; FAITH, B. D.; ACCONCIA, F.; MARINO, M.; FARIAS, R. N.; DAVIS, P. J. Rapid nongenomic effects of 3,5,3'-triiodo-l-thyronine on the intracellular calcium mobilization and kinase pathways. Endocrinology, v. 145, n. 12, p. 5694-5703, 2004.

DAVIS, P. J.; DAVIS, F. B.; HUNG-YUN, L. Promotion by thyroid hormone of cytoplasmto-nucleus shuttling of thyroid hormone receptors. Steroids, v. 73, p. 1013-1017, 2008a.

DAVIS, P. J.; LEONARD, J. L.; DAVIS, F. B. Mechanisms of nongenomic actions of thyroid hormone. Frontiers of Neuroendocrinology, v. 29, p. 211-218, 2008 b. 
DAVIS, P. J.; SHIH, A.; HUNG-YUN, L.; MARTINO, L. J.; DAVIS, F. B. Thyroxine promotes association of mitogenen-activated protein kinase and nuclear thyroid hormone receptor (TR) and causes serine phosphorylation of TR. The Journal of Biological Chemistry, v. 275, n. 48, p. 38032-38039, 2000.

DE ROSA, M.; ZARRILLI, S.; DI SARNO, A.; MILANO, N.; GACCIONE, M.; BOGGIA, B.; LOMBARDI, G.; COLAO, A. Hyperprolactinemia in men: clinical and biochemical features and response to treatment. Endocrine, v. 20, n. 1-2, p. 75-82, 2003.

DILLMANN, W. H.; BARRY, S.; ALEXANDER, N. M. A physiological dose of triiodothyronine normalizes cardiac myosin adenosine triphosphatase activity and changes myosin isoenzyme distribution in semistarved rats. Endocrinology, v. 112, n. 6, p. 2081-2087, 1983.

EVERETT, J. W. Pituitary and Hypothalamus: Perspectives and Overview. In: NEIL, J. D. (Ed). Knobil and Neill's Physiology of Reproduction. 3rd. ed. Amsterdam: Ed Elsevier, 2006. p. 1289-1307.

FEKETE, C.; LECHAN, R. M. Negative feedback regulation of hypophysiotropic thyrotropin-releasing hormone $(\mathrm{TRH})$ synthesizing neurons: role of neuronal afferents and type 2 deiodinase. Frontiers of Neuroendocrinology, v. 28, p. 97-114, 2007.

FIRAT-KARALAR, E. N.; WELCH, M. D.. New mechanisms and functions of actin nucleation. Current Opinion in Cell Biology, v. 23, n. 1, p. 4-13, 2011.

FLIERS, E.; UNMEHOPA, U. A.; ALKEMADE, A. Functional neuroanatomy of thyroid hormone feedback in the human hypothalamus and pituitary gland. Molecular and Cellular Endocrinology, v. 251, n. 1-2, p. 1-8, 2006.

GALLIE, D. R. A tale of two termini: a functional interaction between the termini of an mRNA is a prerequisite for efficient translation initiation. Gene, v. 216, n. 1, p. 1-11, 1998.

GARRIDO-GRACIA, J. C.; GORDON, A.; AGUILAR, R.; MONTERDE, J. G.; BLANCO, A.; MULAS, J. M.; SÁNCHEZ-CRIADO, J. E. Morphological effects of oestradiol-17ß, and selective oestrogen receptor $\mathrm{a}$ and $B$ agonists on luteinising hormonesecreting cells in tamoxifen-treated ovariectomised rats. Histology and Hitopathology, v. 23, p. 1453-1463, 2008.

GAY, V. L. Decreased metabolism and increased serum concentrations of LH and FSH following nephrectomy of the rat: absence of short-loop regulatory mechanisms. Endocrinology, v. 95, n. 6, p. 1582-1588, 1975. 
GLOSS, B.; GIANNOCCO, G.; SWANSON E. A.; MORISCOT, A. S.; CHIELLINI, G.; SCANLAN, T.; BAXTER, J. D.; DILLMANN, W. H. Different configurations of specific thyroid hormone response elements mediate opposite effects of thyroid hormone and GC-1 on gene expression. Endocrinology, v. 146, p. 4926-4933, 2005.

GOYAL, H. O.; BRADEN, T. D.; MANSOUR, M.; WILLIAMS, C. S.; KAMALELDIN, A.; SRIVASTAVA, K. K. Diethylstilbestrol-treated adult rats with altered epididymal sperm numbers and sperm motility parameters, but without alterations in sperm production and sperm morphology. Biology of Reproduction, v. 64, p. 927-934, 2001.

GOULART-SILVA, F.; GIANNOCCO, G.; SANTOS, M. F.; NUNES, M. T. Thyroid hormone induction of actin polymerization in somatotrophs of hypothyroid rats: potential repercussions in growth hormone synthesis and secretion. Endocrinology, v. 12, p. 57775785, 2006.

GOULART-SILVA, F.; SOUZA, P. B.; NUNES, M. T. T3 rapidly modulates TSH $\beta$ mRNA stability and translational rate in the pituitary of hypothyroid rats. Molecular and Cellular Endocrinology, v. 332, n. 1-2, p. 277-282, 2010.

GUYTON, A. C.; HALL, J. E. Tratado de fisiologia médica. 11. ed. Rio de Janeiro: Elsevier, 2005 .

HATSUTA, M.; ABE, K.; TAMURA, K.; RYUNO, T.; WATANABE, G.; TAYA, K.; $\mathrm{KOGO}, \mathrm{H}$. Effects of hypothyroidism on the estrous cycle and reproductive hormones in mature female rat. European Journal of Pharmacology, v. 486, p. 343-348, 2004.

HEKIMSOY, Z.; KAFESÇILER, S.; GÜÇLÜ, F.; ÖZMEN, B. The prevalence of hyperprolactinaemia in overt and subclinical hypothyroidism. Endocrine Journal, v. 57, n. 12, p. 1011-1015, 2010.

IGLESIAS, P.; DÍEZ, J. J. Thyroid dysfunction and kidney disease. European Journal of Endocrinology, v. 160, n. 4, p. 503-515, 2009.

JANNINI, E. A.; CRESCENZI, A.; RUCCI, N.; SCREPONI, E.; CAROSA, E.; DEMATTEIS, A.; MACCHIA, E.; D'AMATI, G.; D'ARMIENTO, M. Ontogenetic pattern of thyroid hormone receptor expression in the human testis. The Journal of Clinical Endocrinology and Metabolism, v. 85, n. 9, p. 3453-3457, 2000.

JANNINI, E. A.; OLIVIERI, M.; FRANCAVILLA, S.; GULINO, A.; ZIPARO, E.; D'ARMIENTO, M. Ontogenesis of the nuclear 3,5,3'-triiodothyronine receptor in the rat testis. Endocrinology, v. 126, n. 5, p. 2521-2526, 1990 
JANNINI, E. A.; ULISSE, S.; D'ARMIENTO, M. Thyroid hormone and male gonadal function. Endocrine Reviews, v. 16, n. 4, p. 443-459, 1995

JELINSKY, S. A.; TURNER, T. T.; BANG, H. J.; FINGER, J. N.; SOLARZ, M. K.; EWA WILSON, E.; BROWN, E. L.; KOPF, G. S.; JOHNSTON, D. S. The rat epididymal transcriptome: comparison of segmental gene expression in the rat and mouse epididymides. Biology of Reproduction, v. 76, p. 561-570, 2007.

JOSHI, A. S.; WOOLF, P. D. Pituitary hyperplasia secondary to primary hypothyroidism: a case report and review of the literature. Pituitary, v. 8, p. 99-103, 2005.

KERR, J. B.; LOVELAND, K. L.; O'BRYAN, M. K.; DE KRETSER, D. M. Cytology of the testis and intrinsic control mechanisms. In: NEIL, J. D. (Ed.). Knobil and Neill's Physiology of Reproduction. 3rd. ed. Amsterdam: Elsevier, 2006. p. 829-947.

KITAHARA, K.; SAKAI, Y.; HOSAKA, M.; HIRA, Y.; KAKIZAKI, H.; WATANABE, T. Effects of a depot formulation of the GnRH agonist leuprolin on the ultraestructure of male rat pituitary gonadotropes. Archives of Histology and Cytology, v. 70, n. 2, p. 79-93, 2007.

KLEIN, I.; DANZI, S. Thyroid disease and the heart. Circulation, v. 116, p. 1725-1735, 2007.

KRASSAS, G. E. Thyroid disease and female reproduction. Fertility and Sterility, v. 74, n. 6, p. 1063-1070, 2000.

KRASSAS, G. E.; PAPADOPOULOU, F.; TZIOMALOS, K.; ZEGINIADOU, T.; PONTIKIDES, N. Hypothyroidism has an adverse effect on human spermatogenesis: a prospective, controlled study. Thyroid, v. 18, n. 12, p. 1255-1259, 2008.

KRETSER, D. M.; ATKINS, R. C.; PAULSEN, C. A. Role of the kidney in the metabolism of luteinizing hormone. Journal of Endocrinology, v. 58, n. 3, p. 425-434, 1973.

KRSMANOVIC, L. Z.; MARTINEZ-FUENTES, A. J.; ARORA, K. K.; MORES, N.; TOMIC, M.; STOJILKOVIC, S. S.; CATT, K. J. Local regulation of gonadotroph function by pituitary gonadotropin-releasing hormone. Endocrinology, v. 141, n. 3, p. 1187-1195, 2000.

LABRIE, F. Blockade of testicular and adrenal androgens in prostate cancer treatment. Nature Reviews Urology, v. 8, p. 73-80, 2011. 
LAN N.; HELlEMANS, K. G. C.; ELLIS, L.; VIAU, V.; WEINBERG, J. Role of testosterone in mediating prenatal ethanol effects on hypothalamic-pituitary-adrenal activity in male rats. Psychoneuroendocrinology, v. 34, n. 9, p. 1314-1328, 2009.

LENZI, A.; BALERCIA, G.; BELLASTELlA, A.; COLAO, A.; FABBRI, A.; FORESTA, C.; GALDIERO, M.; GANDINI, L.; KRAUSZ, C.; LOMBARDI, G.; LOMBARDO, F.; MAGGI, M.; RADICIONI, A.; SELICE, R.; SINISI, A. A.; FORTI, G. Epidemiology, diagnosis, and treatment of male hypogonadotropic hypogonadism. Journal of Endocrinological Investigation, v. 32, n. 11, p. 934-938, 2009.

LOVEJOY, J. C.; SMITH, S. R.; BRAY, G. A.;VELDHUIS, J. D.; ROOD, J. C.; TULLEY, R. Effects of experimentally induced mild hyperthyroidism on growth hormone and insulin secretion and sex steroid levels in healthy young men. Metabolism, v. 46, p. 1424-1428, 1997.

MANNA, P. R.; KERO, J.; TENA-SEMPERE, M.; PAKARINEN, P.; STOCCO, D. M.; HUHTANIEMI, I. T. Assessment of mechanisms of thyroid hormone action in mouse Leydig cells: regulation of the steroidogenic acute regulatory protein, steroidogenesis, and luteinizing hormone receptor function. Endocrinology, v. 142, n. 1, p. 319-331, 2001.

MANNA, P. R.; TENA-SEMPERE, M.; HUHTANIEMI, I. T. Molecular mechanisms of thyroid hormone-stimulated steroidogenesis in mouse leydig tumor cells. Involvement of the steroidogenic acute regulatory (StAR) protein. The Journal of Biological Chemistry, v. 274, n. 9, p. 5909-5918, 1999.

MARAN, R. R. Thyroid hormones: their role in testicular steroidogenesis. Archives of Androlology, v. 49, n. 5, p. 375-388, 2003.

MEIKLE, A. W. The interrelationships between thyroid dysfunction and hypogonadism in men and boys. Thyroid, v. 14, p. S17-S25, 2004. Sup

MIRALLES F.; VISA, N. Actin in transcription and transcription regulation. Current Opinion in Cell Biology, v. 18, n. 3, p. 261-266, 2006.

NOLAN, T.; HANDS, R. E.; BUSTIN, S. A. Quantification of mRNA using real-time RTPCR. Nature Protocols, v.1, n.3, p. 1559-1582, 2006.

NORMAN, A. W.; LITWACK, G. Hormones. 2nd ed. California: Academic Press, 1997. 558 p. 
NUNES, M. T. Fisiologia endócrina. In: AIRES, M. M. (Ed.) Fisiologia. 3. ed. Rio de Janeiro: Editora Guanabara Koogan, 2008. p. 917-1174.

OPPENHEIMER, J. H.; SCHWARTZ, H. L.; SURKS, M. I. Tissue differences in the concentration of triiodothyronine nuclear binding sites in the rat: liver, kidney, pituitary, heart, brain, spleen, and testis. Endocrinology, v. 95, p. 897-903, 1974

ORIDE, A.; KANASAKI, H.; PURWANA, I. N.; MUTIARA, S.; MIYAZAKI, K. Follistatin induced by thyrotropin-releasing hormone (TRH) plays no role in prolactin expression but affects gonadotropin FSHbeta expression as a paracrine factor in pituitary somatolactotroph GH3 cells. Regulatory Peptides, v. 156, p. 65-71, 2009.

O'SHAUGHNESSY, P. J.; MORRIS, I. D.; HUHTANIEMI, I.; BAKER, P.J.; ABEL, M. H. Role of androgen and gonadotrophins in the development and function of the Sertoli cells and Leydig cells: data from mutant and genetically modified mice. Molecular and Cellular Endocrinology, v. 306, n. 1-2, p. 2-8, 2009.

PATRIZIO, P; SANGUINETI, F.; SAKKAS D. Modern andrology: from semen analysis to postgenomic studies of the male gametes. Annals of the New York Academic Sciences, v. 1127, p. 59-63, 2008.

PATRÃO, M. T. C. C.; SILVA, E. J. R.; AVELlAR, M. C. W. Androgens and the male reproductive tract: an overview of classical roles and current perspectives. Arquivo Brasileiro de Endocrinologia e Metabologia, v. 53, n. 8, p. 934-945, 2009.

PAUL, A. L.; MUKDSI, J. H.; PELLIZAS, C. G.; MONTESINOS, M.; SILVINA GUTIÉRREZ, S.; SUSPERREGUY, S.; RIO, A.; MALDONADO, C. A.; TORRES, A. I. Thyroid hormone receptor $\alpha 1-\beta 1$ expression in epididymal epithelium from euthyroid and hypothyroid rats. Histochemistry and Cell Biology, v. 129, p. 631-642, 2008.

PEI-JU, T.; YA-HUI, H.; CHUNG-HSUAN, S.; RUEY-NAN, C.; CHI-DE, C.; WEI-JAN, C.; CHIA-SIU, W.; KWANG-HUEI, L. Direct regulation of androgen receptor-associated protein 70 by Thyroid hormone and its receptors. Endocrinology, v. 148, n. 7, p. 3485-3495, 2007.

PEKARY, A. E.; SATTIN, A. Regulation of TRH and TRH-related peptides in rat brain by thyroid and steroid hormones. Peptides, v. 22, p. 1161-1173, 2001. 
PERELLO, M.; FRIEDMAN, T.; PAEZ-ESPINOSA, V.; SHEN, X.; STUART, R. C.; NILLNI, E. A. Thyroid hormones selectively regulate the posttranslational processing of prothyrotropin-releasing hormone in the paraventricular nucleus of the hypothalamus. Endocrinology, v. 147, n. 6, p. 2705-2716, 2006.

PFAFFL, M. W. A new mathematical model for relative quantification in real-time RT-PCR. Nucleic Acids Research, v. 29, n. 9, p. 2002-2007, 2001.

PORTMAN, M. A. Thyroid hormone regulation of heart metabolism. Thyroid, v. 18, n. 2, p. 217-225, 2008.

PROUD, C. G. Signalling to translation: how signal transduction pathways control the protein synthetic machinery. Biochemistry Journal, v. 403, n. 2, p. 217-234, 2007.

RASMUSSEN, D. D. Chronic daily ethanol and withdrawal: 5. Diurnal effects on plasma thyroid hormone levels. Endocrine, v. 22, n. 3, p. 329-334, 2003.

RISBRIDGER, G. P.; TAYLOR, R. A. Physiology of the male accessory sex structures: the prostate gland, seminal vesicles, and bulbourethral glands. In: NEIL, J. D. (Ed). Knobil and Neill’s Physiology of Reproduction. 3rd ed. Amsterdam: Elsevier, 2006. p. 1149-1172.

ROBAIRE, B.; HINTON, B.; ORGEBIN-CRIST, M. C. The epididymis. In: NEIL, J. D. (Ed). Knobil and Neill's Physiology of Reproduction. 3rd ed. Amsterdam: Elsevier, 2006. p. 1071-1148.

ROBERTSON, K. M.; O’DONNEL, L.; JONES, M. E. E.; MEACHEM, S. J.; BOON, W. C.; FISHER, C. R.; GRAVES, K. H.; MCLACHLAN, R. I.; SIMPSON, E. R. Impairment of spermatogenesis in mice lacking a functional aromatase (cyp19) gene. PNAS - Proceedings of the National Academy of Sciences of the United States of America, v. 96, p. 7986-7991, 1999.

ROLHF, F. J. tpsDig. Versão 2.10. Suny at Stony Brook: Ecology and Evolution. 2006. Disponível em: <http://life.bio.sunysb.edu/morph>. Acesso em: 10 dez. 2008.

ROMANO, R. M.; ROMANO, M. A.; BERNARDI, M. M.; FURTADO, P.V.; OLIVEIRA, C. A. Prepubertal exposure to commercial formulation of the herbicide glyphosate alters testosterone levels and testicular morphology. Archives of Toxicology, v. 84, n. 4, p. 309-317, 2010 . 
ROSONINA, E.; MANLEY, J. L. Alternative polyadenylation blooms. Developmental Cell, v. 18, p. 172-174, 2010.

SAHOO, D. K.; ROY, A.; BHANJA, S.; CHAINY, G. B. N. Hypothyroidism impairs antioxidant defence system and testicular physiology during development and maturation. General and Comparative Endocrinology, v. 156, p. 63-70, 2008.

SALLÉS, F. J.; RICHARDS, W. G.; STRICKLAND, S. Assaying the polyadenylation state of mRNAs. Methods, v. 7, n. 1, p. 38-45, 1999.

SANCHEZ-CRIADO, J.; MULAS, J. M.; BELLIDO, C.; NAVARRO, V. M.; AGUILAR, R.; GARRIDO-GRACIA, J. C.; MALAGON, M. M.; TENA-SEMPERE M.; BLANCO, A. Gonadotropin-secreting cells in ovariectomized rats treated with different oestrogen receptor ligands: a modulatory role for ER $\beta$ in the gonadotrope? Journal of Endocrinology, v. 188, p. 167-177, 2006.

SERRANO-NASCIMENTO, C.; CALIL-SILVEIRA, J.; NUNES, M. T. Posttranscriptional regulation of sodium-iodide symporter mRNA expression in the rat thyroid gland by acute iodide administration. American Journal of Physiology. Cell Physiology, v. 298, n. 4, p. C893-C899, 2010.

SHEUE-YANN, C.; LEONARD, J. L.; DAVIS, P. J. Molecular aspects of thyroid hormone actions. Endocrine Reviews, v. 31, n. 2, p. 139-170, 2010.

SIEGRIST-KAISER, C.; JUGE-AUBRY, C.; TRANTER, M. P.; EKENBERGER, D. M.; LEONARD, J. L. Thyroxine-dependent modulation of actin polymerization in cultured astrocytes. The Journal of Biological Chemistry, v. 265, n. 9, p. 5296-5302, 1990.

SILVA, F. G.; GIANNOCCO, G.; LUCHESSI, A. D.; CURI, R.; NUNES, M. T. T3 acutely increases GH mRNA translation rate and GH secretion in hypothyroid rats. Molecular and Cellular Endocrinology, v. 317, n. 1-2, p. 1-7, 2010.

SOFIKITIS, N.; GIOTITSAS, N.; TSOUNAPI, P.; BALTOGIANNIS, D.; GIANNAKIS, D.; PARDALIDIS, N. Hormonal regulation of spermatogenesis. The Journal of Steroid Biochemistry and Molecular Biology, v. 109, n. 3-5, p. 323-330, 2008.

SORENSON, R. L.; STOUT, L. E.; BRELJE, C.; JETTON, T. L.; MATSCHINSKY, M. Immunohistochemical evidence for the presence of glucokinase in the gonadotropes and thyrotropes of the anterior pituitary gland of rat and monkey. Journal of Histochemistry and Cytochemistry, v. 55, n. 6, p. 555-566, 2007. 
STATON, J. M.; THOMSON, A. M.; LEEDMAN, P. J. Hormonal regulation of mRNA stability and RNA-protein interactions in the pituitary. Journal of Molecular Endocrinology, v. 25, n. 1, p. 17-34, 2000.

STOCCO, D. M.; CLARK, B. J. Regulation of the acute production of steroids in steroidogenic cells. Endocrine Reviews, v. 17, n. 3, p. 221-244, 1996.

TOHEI, A.; AKAI, M.; TOMABECHI, T.; MAMADA, M.; TAKAI, K. Adrenal and gonadal function in hypothyroid adult male rats. Journal of Endocrinology, v. 152, n. 1, p. 147-154, 1997.

TONI, R.; DELLA CASA, C.; CASTORINA, S.; COCCHI, D.; CELOTTI, F. Effects of hypothyroidism and endocrine disruptor-dependent non-thyroidal illness syndrome on the GnRH-gonadotroph axis of the adult male rat. Journal of Endocrinology Investigation, v. 28, p. 20-27, 2005. Suppl. 11.

VALENTI, S.; GUIDO, R.; FAZZUOLI, L.; BARRECA, A.; GIUSTI, M.; GIORDANO, G. Decreased steroidogenesis and cAMP production in vitro by leydig cells isolated from rats made hypothyroid during adulthood. International Journal of Andrology, v. 20, n. 5, p. 279286, 1997.

VAN DEN BERGHE, G.; BAXTER, R. C.; WEEKERS, F.; WOUTERS, P.; BOWERS, C. Y.; IRANMANESH, A.; VELDHULS, J. D.; BOUILLON, R. The combined administration of GH-releasing peptide-2 (GHRP-2), TRH and GnRH to men with prolonged critical illness evokes superior endocrine and metabolic effects compared to treatment with GHRP-2 alone. Clinical Endocrinology, v. 56, p. 655-669, 2002.

WAGNER, M. S.; WAJNER, S. M.; MAIA, A. L. The Role of Thyroid Hormone in Testicular Development and Function. Journal of Endocrinology, v. 199, n. 3, p. 351-365, 2008.

WAJNER, S. M.; WAGNER, M. S.; MELO, R. C. N.;PARREIRA, G. G.; CHIARINIGARCIA, H.; BIANCO, A. C.; FEKETE, C.; SANCHEZ, E.; LECHAN, R. M.; MAIA, A. L. Type 2 iodothyronine deiodinase is highly expressed in germ cells of adult rat testis. Journal of Endocrinology, v. 194, p. 47-54, 2007.

WALKER, W. H.; CHENG, J. FSH and testosterone signaling in Sertoli cells. Reproduction, v. 130, n. 1, p. 15-28, 2005.

WANG, L.; CHENG-LUNG, H.; CHAWN-SHANG, C. Androgen receptor corepressors: an overview. Prostate, v. 63, n. 2, p. 117-130, 2005. 
WARTOFSKY, L.; VAN NOSTRAND, D.; BURMAN, K. D. Overt and subclinical hypothyroidism in women. Obstetrical and Gynecological Survey, v. 61, n. 8, p. 535-542, 2006.

WATANABE, T.; BANNO, T.; JEZIOROWSKI, T.; OHSAWA, Y.; WAGURI, S.; GRUBE, D.;UCHIYAMA, Y. Effects of sex steroids on secretory granule formation in gonadotropes of castrated male rats with respect to granin expression. Endocrinology, v. 139, n. 6, p. 27652773, 1998.

YEN, P. M. Physiological and molecular basis of thyroid hormone action. Physiological Reviews, v. 81, n. 3, p. 1097-1142, 2001.

ZHOU, W.; WANG,G.; SMALL,C. L.; LIU, Z.; WENG,C. C.; YANG, L.; GRISWOLD, M. D.; MEISTRICH, M. L. Gene expression alterations by conditional knockout of androgen receptor in adult Sertoli cells of Utp14b jsd/jsd (jsd) mice. Biology of Reproduction, v. 84, p. 400-408, 2011. 